\title{
UK Renal Registry 19th Annual Report: Chapter 8 Biochemical Variables amongst UK Adult Dialysis Patients in 2015: National and Centre-specific Analyses
}

\author{
Shona Methven ${ }^{a}$, Lydia lyamu Perisanidou ${ }^{b}$, Johann Nicholas ${ }^{c}$, Anne Dawnay $^{d}$

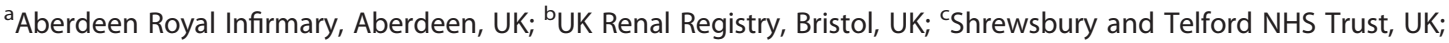 \\ dBarts Health NHS Trust, London, UK
}

\section{Keywords}

Bicarbonate - Biochemical variables - Calcium - Dialysis . Haemodialysis - Parathyroid hormone - Peritoneal dialysis . Phosphate · Quality improvement

\section{Summary}

In 2015

- $64.1 \%$ of haemodialysis (HD) patients and $60.5 \%$ of peritoneal dialysis (PD) patients achieved the Renal Association (RA) audit measure for phosphate $(<1.7 \mathrm{mmol} / \mathrm{L})$.

- $35.9 \%$ of HD and $39.5 \%$ of PD patients had a serum phosphate above the RA audit standard $(\geqslant 1.7 \mathrm{mmol} / \mathrm{L})$.
- Simultaneous control of all three parameters (calcium, phosphate and parathyroid hormone $(\mathrm{PTH})$ ) within current target ranges was achieved by $27.6 \%$ of $\mathrm{HD}$ and $33.1 \%$ of PD patients.

- $79.3 \%$ of HD and $77.8 \%$ of PD patients had adjusted calcium in the recommended target range of 2.2$2.5 \mathrm{mmol} / \mathrm{L}$

- $57.1 \%$ of HD and $61.3 \%$ of PD patients had phosphate between $1.1-1.7 \mathrm{mmol} / \mathrm{L}$.

- $56.8 \%$ of HD and $63.6 \%$ of PD patients had a serum PTH between 16-72 pmol/L.

- $18.8 \%$ of HD and $13.9 \%$ of PD patients had a serum $\mathrm{PTH}>72 \mathrm{pmol} / \mathrm{L}$.

- $64.3 \%$ of $\mathrm{HD}$ and $80.4 \%$ of PD patients achieved the audit measure for bicarbonate $18-24 \mathrm{mmol} / \mathrm{L}$ for $\mathrm{HD}$ patients and $22-30 \mathrm{mmol} / \mathrm{L}$ for $\mathrm{PD}$ patients).

\section{KARGER}

Fax +41613061234 E-Mail karger@karger.com www.karger.com/nef
This article is licensed under the Creative Commons AttributionNonCommercial-NoDerivatives 4.0 International License (CC BYNC-ND) (http://www.karger.com/Services/OpenAccessLicense). Usage and distribution for commercial purposes as well as any distribution of modified material requires written permission
Shona Methven

UK Renal Registry, Southmead Hospital, Southmead Road,

Bristol, BS10 5NB, UK

Email: renalregistry@renalregistry.nhs.uk 


\section{Introduction}

The UK Renal Registry (UKRR) collects routine biochemical data from clinical information systems in renal centres in England, Wales and Northern Ireland and receives data from Scotland via the Scottish Renal Registry. Annual cross-sectional analyses are undertaken on some of these variables to determine centre level performance against national (Renal Association (RA)) clinical performance measures [1]. This enables UK renal centres to compare their own performance against each other and to the UK average performance. International chronic kidney disease - mineral bone disorder (CKD-MBD) guidelines were published in 2009 [2] and this prompted changes in CKD-MBD guidelines around the world. Therefore a review of the 5th edition of the RA guidelines was undertaken in order to outline the UK response. These updated RA guidelines were one of the first published by the RA in the 6th edition of their guidelines in March 2015 [3]. Data from 2015 are reported in this chapter, from quarters $2-4$, immediately after these updated guidelines were published. The updated RA guidelines offer two audit measures, firstly the proportion of patients with serum phosphate $<1.7 \mathrm{mmol} / \mathrm{L}$ and secondly the proportion of patients with all bone parameters within target range. The target range for phosphate recommended in the guideline is $1.1-1.7 \mathrm{mmol} / \mathrm{L}$ (not $<1.7 \mathrm{mmol} / \mathrm{L}$ as for the phosphate audit measure). Therefore the authors have interpreted the latter audit measure to include this recommended target range for phosphate of $1.1-1.7 \mathrm{mmol} / \mathrm{L}$ which results in different measures of phosphate being used at different points in the chapter and readers should be aware of this when interpreting these results.

Audit measures for kidney disease increasingly include tighter specification limits in conjunction with a growing evidence base. Out of range observations (e.g. hyperphosphataemia or PTH below target range) need to be interpreted cautiously as they may relate to different clinical problems or population characteristics. These will therefore require different strategies to improve centre performance of clinical audit measures. Summary statistical data have been provided to enhance understanding of the population characteristics of each centre and longitudinal analyses to demonstrate changes over time.

Data are also available on the UKRR data portal at www.renalreg.org.

Table 8.1 lists the recommended biochemical based audit measures from the RA which are relevant to the dialysis population. Several of the audit measures are not currently reported by the UKRR in its annual report; the reasons behind this are varied, but predominantly relate to a high proportion of incomplete data or the relevant variable not being within the specified UKRR dataset. The UKRR is actively working with renal centres to collect more granular and wide ranging data using new methods of data collection.

\section{Methods}

The analyses presented in this chapter relate to biochemical variables in the prevalent dialysis cohort in the UK. The cohort studied were patients prevalent on dialysis treatment on 31st December 2015. Patients receiving dialysis for less than 90 days and those who had changed modality or renal centre in the last 90 days were excluded. Haemodialysis (HD) and peritoneal dialysis (PD) cohorts were analysed separately. A full definition of the cohort including inclusion and exclusion criteria is available in appendix B (www.renalreg.org).

The biochemical variables analysed in this chapter were serum phosphate, calcium (adjusted for albumin), PTH and bicarbonate. The method of data collection and validation by the UKRR has been previously described [4]. In brief, for each quarter of 2015 the UKRR extracted biochemical data electronically from clinical information systems in renal centres in England, Wales and Northern Ireland (E,W\&NI). Cambridge renal centre (Addenbrooke's) was not able to submit the 2015 data at patient level on time for the end of 2015 data collection period. Scottish centres have only been included in analyses relating to corrected calcium and phosphate control, with data for their prevalent dialysis cohort being supplied directly by the Scottish Renal Registry. The UKRR does not currently collect data regarding different assay methods mainly because a single dialysis centre may process samples in several different laboratories. The audit measure used for serum phosphate was $<1.7 \mathrm{mmol} / \mathrm{L}$ in both the HD and PD cohorts $[1,3]$. However, for the audit measure of composite control of bone parameters it is recommended that all parameters are within the target range and this includes phosphate within the range of 1.1-1.7 $\mathrm{mmol} / \mathrm{L}$, so two different phosphate measures are in use in this report. For centres providing adjusted calcium values, these data were analysed directly as it is these values on which clinical decisions within centres are based. For centres providing unadjusted calcium values, a formula in widespread use was used to calculate adjusted calcium [5]. The audit measure for adjusted calcium depends on the local reference range [3]. For the purposes of these analyses, the UKRR has used the RA guideline standard of adjusted calcium between $2.2-2.5 \mathrm{mmol} / \mathrm{L}$ as the audit measure [3]. There are also a variety of methods and reference ranges in use to measure PTH. To enable some form of comparative audit the UKRR has used two to nine times the median upper limit of the reference range $(8 \mathrm{pmol} / \mathrm{L})$ as the audit measure in line with the RA clinical practice guidelines and KDIGO 2009 guidance [2, 3]. This equates to a PTH range of $16-72 \mathrm{pmol} / \mathrm{L}$. The audit measure used for serum bicarbonate in the HD cohort was $18-24 \mathrm{mmol} / \mathrm{L}$ as per the updated HD guidelines and in the PD cohort was $22-30 \mathrm{mmol} / \mathrm{L}$. A summary 
Table 8.1. Summary of Renal Association audit measures for biochemical variables [1]

\begin{tabular}{lcc}
\hline & $\begin{array}{c}\text { Included in UKRR } \\
\text { annual report }\end{array}$ & Reason \\
\hline
\end{tabular}

CKD-MBD in CKD stage 5D audit measures

Percentage of patients CKD5D with serum $\mathrm{PO}_{4}$ $<1.7 \mathrm{mmol} / \mathrm{L}$

Percentage of patients with all bone parameters within target range $(\mathrm{Ca} / \mathrm{P} / \mathrm{PTH})$

\section{Peritoneal dialysis guidelines}

Cumulative frequency curves of plasma bicarbonate

\section{Haemodialysis guidelines}

Cumulative frequency curves of pre-dialysis potassium concentration

Cumulative frequency curves of pre-dialysis serum calcium (adjusted for albumin) and phosphate concentrations

\section{Cardiovascular disease in CKD guidance}

Record of HbAlc concentrations in IFCC ( $\mathrm{mmol} / \mathrm{mol})$ and/or DCCT (\%) units

Cholesterol concentrations in patients prescribed HMG CoA reductase inhibitors

Yes

Yes
Target ranges used for this analysis: adjusted calcium 2.2-2.5 $\mathrm{mmol} / \mathrm{L}$, phosphate $1.1-1.7 \mathrm{mmol} / \mathrm{L}$

(please note this is different from audit measure of $<1.7 \mathrm{mmol} / \mathrm{L}$ ) and PTH $16-72 \mathrm{pmol} / \mathrm{L}$

(2-9 $\times$ upper end of reference range)

Summary measures at centre and country level are presented in various formats but not as cumulative frequency curves

It is hoped for the next report that data completeness will enable analysis. There are also concerns that potential delays in blood sample processing may result in over estimates of potassium concentrations

No Summary measures at centre and country level are presented in various formats but not as cumulative frequency curves

No Poor data completeness

No The UKRR has reported summary statistics for total cholesterol. These summary data were presented on 2013 data and will be presented again on 2016 data. Reliable information is not currently available within the UKRR data on statin prescription

IFCC International Federation of Clinical Chemistry

DCCT Diabetes Control and Complications Trial

of the current RA audit measures for these variables and conversion factors to SI units are given in table 8.2.

Quarterly values were extracted from the database for the last two quarters for calcium, phosphate and bicarbonate and the last three quarters for PTH. Patients who did not have these data were excluded from the analyses. Data completeness was analysed at centre and country level. All patients were included in analyses but centres with less than $50 \%$ completeness were excluded from plots and tables showing centre level performance. Data were also excluded from plots and tables when there were fewer than 10 patients with data, both at centre or country level. These data were analysed to calculate summary descriptive

Table 8.2. Summary of clinical guideline target ranges and conversion factors from SI units

\begin{tabular}{llc}
\hline Biochemical variable & Clinical guideline measure & Conversion factor from SI units \\
\hline Phosphate $^{*}$ & HD patients: $1.1-1.7 \mathrm{mmol} / \mathrm{L}$ & $\mathrm{mg} / \mathrm{dl}=\mathrm{mmol} / \mathrm{L} \times 3.1$ \\
Calcium (adjusted) & PD patients: $1.1-1.7 \mathrm{mmol} / \mathrm{L}$ & $\mathrm{mg} / \mathrm{dl}=\mathrm{mmol} / \mathrm{L} \times 4$ \\
Parathyroid hormone & Normal range (ideally $2.2-2.5 \mathrm{mmol} / \mathrm{L})$ & $\mathrm{ng} / \mathrm{L}=\mathrm{pmol} / \mathrm{L} \times 9.4$ \\
Bicarbonate & $2-9$ times upper limit of normal & $\mathrm{mg} / \mathrm{dl}=\mathrm{mmol} / \mathrm{L} \times 6.1$ \\
& HD patients: $18-24 \mathrm{mmol} / \mathrm{L}$ &
\end{tabular}

\footnotetext{
*There are two measures for phosphate in use: 1 . phosphate clinical audit measure is $<1.7 \mathrm{mmol} / \mathrm{L}$ while 2 . the combined CKD-MBD audit measure assesses all parameters within the target ranges listed in the table which includes phosphate within $1.1-1.7 \mathrm{mmol} / \mathrm{L}$
} 
statistics (maximum, minimum, means with the corresponding standard deviation, medians and interquartile ranges). Where applicable, the percentage achieving the Renal Association standard or other surrogate clinical performance measure was also calculated.

The simultaneous control of all three components of bone and mineral disorder (BMD) parameters were analysed in combination. The proportion of patients with control of none, one, two or three parameters are presented. For the purpose of these analyses an adjusted calcium between $2.2-2.5 \mathrm{mmol} / \mathrm{L}$, a phosphate level being maintained between 1.1-1.7 mmol/L and a PTH level between two and nine times the upper limit of normal (i.e. $16-72 \mathrm{pmol} / \mathrm{L}$ ), were evaluated in combination.

Centres report several biochemical variables with different levels of accuracy, leading to problems in comparative evaluation. For example, in the case of serum bicarbonate, data can be submitted as integer values but some centres submit data to one decimal place. All data have been rounded in an attempt to make centres more comparable.

The number preceding the centre name in each figure indicates the percentage of missing data for that centre. Funnel plot analyses were used to identify outlying centres [6]. The percentage within range for each standard was plotted against centre size along with the upper and lower 95\% and $99.9 \%$ limits. Centres can be identified on these plots by looking up the number of patients treated in each centre in the relevant table and finding this value on the x-axis. Longitudinal analyses were performed for some data to calculate overall changes in achievement of a performance measure annually from 2005 to 2015 and were recalculated for each previous year using the rounding procedure.

All data are presented unadjusted for case-mix.

\section{Results}

\section{Mineral and bone variables}

Phosphate

In 2015 the following Renal Association clinical practice guideline regarding phosphate management was applicable:

\section{Guideline 3.2 CKD-MBD: Serum phosphate in dialysis patients}

\section{Audit measure: Percentage of patients CKD5D with} serum $\mathrm{PO}_{4}<1.7 \mathrm{mmol} / \mathrm{L}[3]$

Overall, data from 22,081 HD and 3,002 PD patients across the UK were included in the analyses of serum

Table 8.3. Summary statistics for serum phosphate in haemodialysis patients in 2015

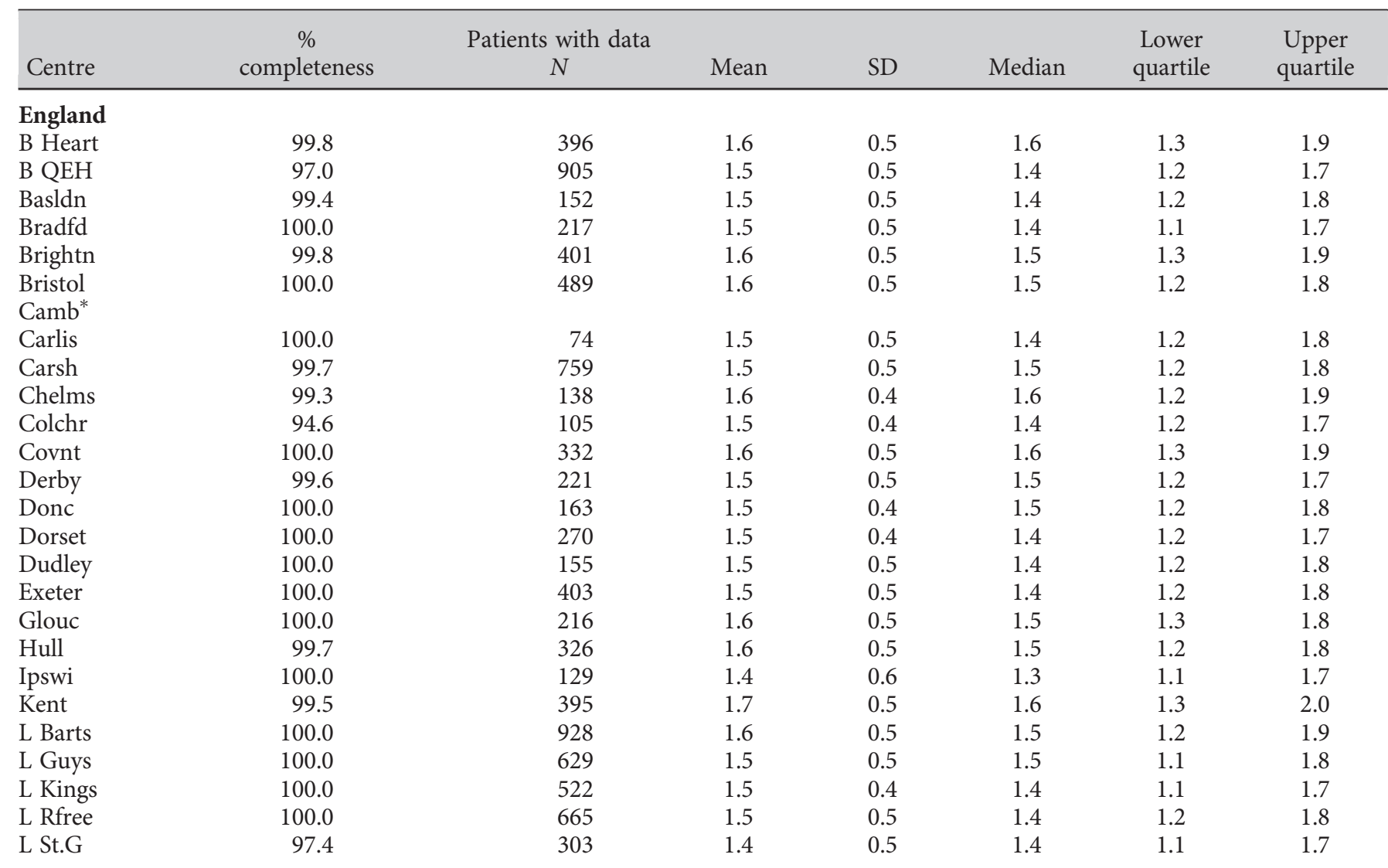


Table 8.3. Continued

\begin{tabular}{|c|c|c|c|c|c|c|c|}
\hline Centre & $\begin{array}{c}\% \\
\text { completeness }\end{array}$ & $\begin{array}{l}\text { Patients with data } \\
\qquad N\end{array}$ & Mean & SD & Median & $\begin{array}{l}\text { Lower } \\
\text { quartile }\end{array}$ & $\begin{array}{l}\text { Upper } \\
\text { quartile }\end{array}$ \\
\hline L West & 91.8 & 1,259 & 1.5 & 0.5 & 1.4 & 1.1 & 1.7 \\
\hline Leeds & 100.0 & 470 & 1.6 & 0.5 & 1.5 & 1.2 & 1.9 \\
\hline Leic & 100.0 & 839 & 1.6 & 0.5 & 1.5 & 1.2 & 1.8 \\
\hline Liv Ain & 98.1 & 155 & 1.3 & 0.5 & 1.3 & 1.0 & 1.6 \\
\hline Liv Roy & 99.4 & 354 & 1.5 & 0.5 & 1.5 & 1.2 & 1.8 \\
\hline M RI & 93.7 & 445 & 1.5 & 0.5 & 1.5 & 1.1 & 1.9 \\
\hline Middlbr & 100.0 & 323 & 1.6 & 0.5 & 1.6 & 1.3 & 1.9 \\
\hline Newc & 100.0 & 285 & 1.6 & 0.5 & 1.5 & 1.2 & 1.9 \\
\hline Norwch & 99.7 & 311 & 1.5 & 0.5 & 1.4 & 1.2 & 1.7 \\
\hline Nottm & 100.0 & 350 & 1.5 & 0.4 & 1.4 & 1.2 & 1.7 \\
\hline Oxford & 99.5 & 396 & 1.6 & 0.6 & 1.6 & 1.2 & 1.9 \\
\hline Plymth & 98.5 & 127 & 1.6 & 0.5 & 1.5 & 1.3 & 1.9 \\
\hline Ports & 99.7 & 615 & 1.6 & 0.5 & 1.6 & 1.3 & 1.9 \\
\hline Prestn & 100.0 & 531 & 1.6 & 0.5 & 1.5 & 1.3 & 1.9 \\
\hline Redng & 100.0 & 283 & 1.5 & 0.5 & 1.5 & 1.2 & 1.8 \\
\hline Salford & 99.7 & 366 & 1.5 & 0.5 & 1.5 & 1.2 & 1.8 \\
\hline Sheff & 99.6 & 515 & 1.5 & 0.4 & 1.5 & 1.2 & 1.8 \\
\hline Shrew & 100.0 & 193 & 1.6 & 0.5 & 1.5 & 1.2 & 1.9 \\
\hline Stevng & 100.0 & 468 & 1.6 & 0.5 & 1.6 & 1.3 & 1.9 \\
\hline Sthend & 100.0 & 108 & 1.6 & 0.5 & 1.6 & 1.3 & 1.9 \\
\hline Stoke & 97.4 & 300 & 1.5 & 0.5 & 1.5 & 1.2 & 1.8 \\
\hline Sund & 0.0 & 0 & & & & & \\
\hline Truro & 100.0 & 145 & 1.5 & 0.5 & 1.4 & 1.2 & 1.8 \\
\hline Wirral & 99.4 & 176 & 1.5 & 0.5 & 1.4 & 1.2 & 1.8 \\
\hline Wolve & 99.3 & 284 & 1.5 & 0.6 & 1.4 & 1.1 & 1.8 \\
\hline York & 100.0 & 145 & 1.4 & 0.4 & 1.3 & 1.0 & 1.6 \\
\hline \multicolumn{8}{|l|}{ N Ireland } \\
\hline Antrim & 100.0 & 114 & 1.4 & 0.4 & 1.3 & 1.1 & 1.6 \\
\hline Belfast & 100.0 & 169 & 1.5 & 0.6 & 1.4 & 1.1 & 1.8 \\
\hline Newry & 100.0 & 84 & 1.6 & 0.5 & 1.6 & 1.3 & 1.8 \\
\hline Ulster & 100.0 & 97 & 1.5 & 0.5 & 1.5 & 1.2 & 1.8 \\
\hline West NI & 100.0 & 113 & 1.6 & 0.4 & 1.6 & 1.3 & 1.8 \\
\hline \multicolumn{8}{|l|}{ Scotland } \\
\hline Abrdn & 100.0 & 205 & 1.4 & 0.4 & 1.4 & 1.1 & 1.7 \\
\hline Airdrie & 100.0 & 174 & 1.4 & 0.5 & 1.4 & 1.1 & 1.7 \\
\hline D \& Gall & 94.2 & 49 & 1.6 & 0.4 & 1.5 & 1.2 & 1.9 \\
\hline Dundee & 98.8 & 171 & 1.7 & 0.5 & 1.7 & 1.3 & 2.0 \\
\hline Edinb & 98.0 & 247 & 1.7 & 0.5 & 1.7 & 1.4 & 2.0 \\
\hline Glasgw & 98.2 & 535 & 1.7 & 0.5 & 1.6 & 1.3 & 1.9 \\
\hline Inverns & 98.7 & 77 & 1.7 & 0.4 & 1.7 & 1.4 & 2.0 \\
\hline Klmarnk & 100.0 & 124 & 1.4 & 0.5 & 1.4 & 1.1 & 1.7 \\
\hline Krkcldy & 100.0 & 132 & 1.5 & 0.4 & 1.5 & 1.2 & 1.8 \\
\hline \multicolumn{8}{|l|}{ Wales } \\
\hline Bangor & 100.0 & 78 & 1.5 & 0.5 & 1.4 & 1.1 & 1.7 \\
\hline Cardff & 99.8 & 459 & 1.6 & 0.5 & 1.5 & 1.2 & 1.8 \\
\hline Clwyd & 100.0 & 76 & 1.7 & 0.5 & 1.6 & 1.3 & 2.0 \\
\hline Swanse & 100.0 & 342 & 1.5 & 0.5 & 1.5 & 1.2 & 1.7 \\
\hline Wrexm & 100.0 & 99 & 1.2 & 0.5 & 1.2 & 0.9 & 1.4 \\
\hline England & 97.8 & 18,736 & 1.5 & 0.5 & 1.5 & 1.2 & 1.8 \\
\hline $\mathrm{N}$ Ireland & 100.0 & 577 & 1.5 & 0.5 & 1.5 & 1.2 & 1.8 \\
\hline Scotland & 98.8 & 1,714 & 1.6 & 0.5 & 1.6 & 1.2 & 1.9 \\
\hline Wales & 99.9 & 1,054 & 1.5 & 0.5 & 1.4 & 1.2 & 1.7 \\
\hline UK & 98.0 & 22,081 & 1.5 & 0.5 & 1.5 & 1.2 & 1.8 \\
\hline
\end{tabular}

Blank cells: centres excluded from analysis due to low patient numbers or poor data completeness

* Cambridge renal centre was unable to submit serum phosphate data for 2015 
Table 8.4. Percentage of haemodialysis patients with serum phosphate below and equal to or above $1.7 \mathrm{mmol} / \mathrm{L}$, as specified in the RA audit measure, by centre in 2015

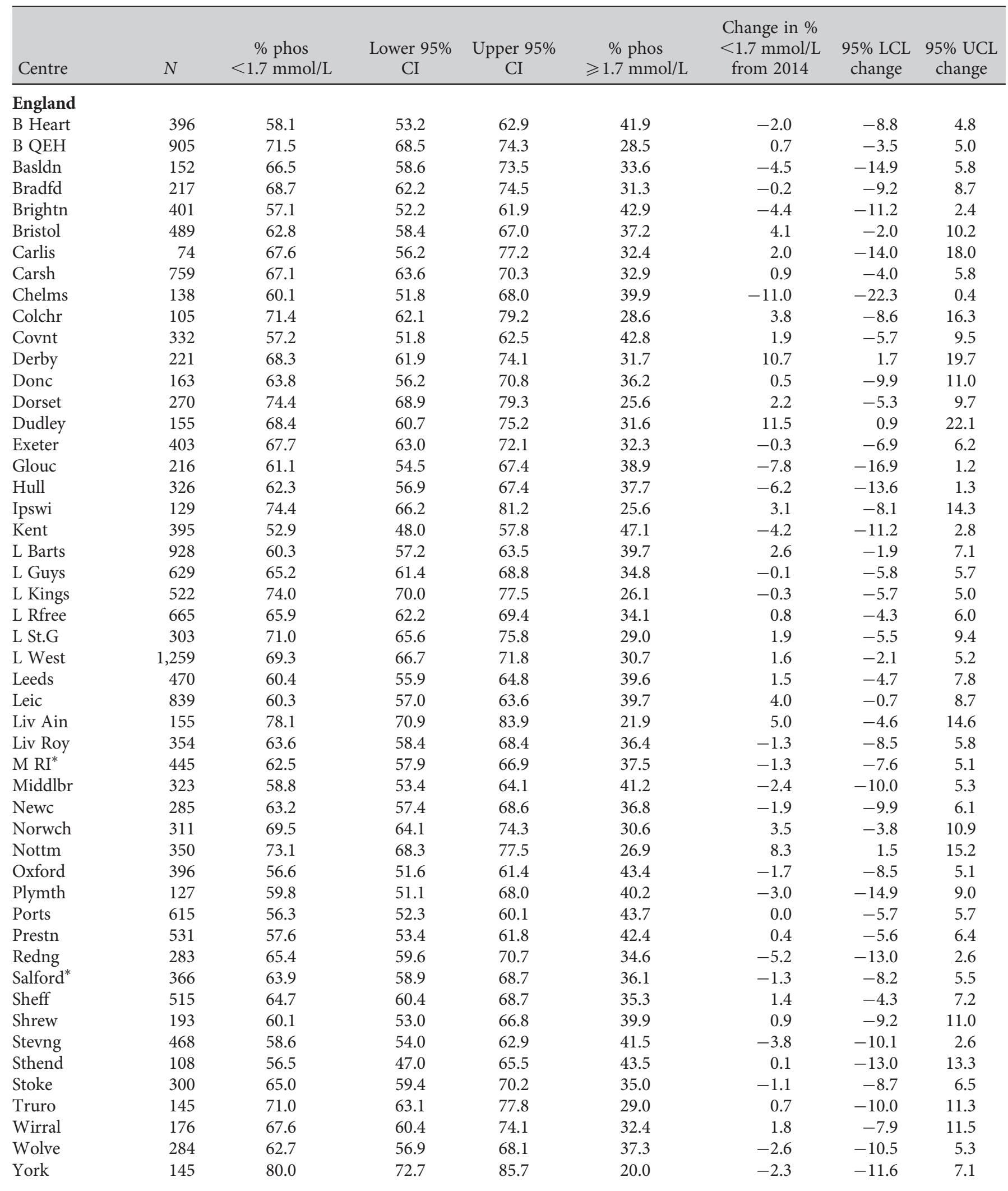


Table 8.4. Continued

\begin{tabular}{|c|c|c|c|c|c|c|c|c|}
\hline Centre & $N$ & $\begin{array}{c}\% \text { phos } \\
<1.7 \mathrm{mmol} / \mathrm{L}\end{array}$ & $\begin{array}{c}\text { Lower } 95 \% \\
\text { CI }\end{array}$ & $\begin{array}{c}\text { Upper } 95 \% \\
\text { CI }\end{array}$ & $\begin{array}{c}\% \text { phos } \\
\geqslant 1.7 \mathrm{mmol} / \mathrm{L}\end{array}$ & $\begin{array}{l}\text { Change in } \% \\
<1.7 \mathrm{mmol} / \mathrm{L} \\
\text { from } 2014\end{array}$ & $\begin{array}{c}95 \% \text { LCL } \\
\text { change }\end{array}$ & $\begin{array}{l}95 \% \text { UCL } \\
\text { change }\end{array}$ \\
\hline \multicolumn{9}{|l|}{ N Ireland } \\
\hline Antrim & 114 & 76.3 & 67.7 & 83.2 & 23.7 & 1.6 & -9.7 & 12.8 \\
\hline Belfast & 169 & 63.3 & 55.8 & 70.2 & 36.7 & -2.3 & -12.2 & 7.6 \\
\hline Newry & 84 & 64.3 & 53.5 & 73.8 & 35.7 & 5.0 & -9.6 & 19.6 \\
\hline \multicolumn{9}{|l|}{ Scotland } \\
\hline Abrdn & 205 & 74.2 & 67.7 & 79.7 & 25.9 & 12.4 & 3.2 & 21.5 \\
\hline Airdrie & 174 & 70.1 & 62.9 & 76.5 & 29.9 & -1.1 & -10.6 & 8.4 \\
\hline D \& Gall & 49 & 63.3 & 49.1 & 75.5 & 36.7 & 7.7 & -12.1 & 27.5 \\
\hline Dundee & 171 & 48.0 & 40.6 & 55.4 & 52.1 & -4.2 & -14.9 & 6.5 \\
\hline Edinb & 247 & 49.4 & 43.2 & 55.6 & 50.6 & -1.4 & -10.1 & 7.3 \\
\hline \multicolumn{9}{|l|}{ Wales } \\
\hline Bangor & 78 & 74.4 & 63.6 & 82.8 & 25.6 & 4.7 & -9.3 & 18.8 \\
\hline Cardff & 459 & 65.8 & 61.3 & 70.0 & 34.2 & 1.3 & -4.9 & 7.4 \\
\hline Clwyd & 76 & 54.0 & 42.7 & 64.8 & 46.1 & -1.5 & -17.0 & 14.0 \\
\hline Swanse & 342 & 68.4 & 63.3 & 73.1 & 31.6 & -0.8 & -7.9 & 6.2 \\
\hline Wrexm & 99 & 88.9 & 81.0 & 93.7 & 11.1 & 17.3 & 6.6 & 28.0 \\
\hline England & 18,736 & 64.3 & 63.6 & 65.0 & 35.7 & 0.3 & -0.7 & 1.3 \\
\hline N Ireland & 577 & 65.2 & 61.2 & 68.9 & 34.8 & 0.5 & -5.0 & 6.0 \\
\hline Scotland & 1,714 & 58.7 & 56.3 & 61.0 & 41.3 & 0.4 & -2.9 & 3.7 \\
\hline Wales & 1,054 & 68.6 & 65.7 & 71.3 & 31.4 & 2.3 & -1.8 & 6.3 \\
\hline UK & 22,081 & 64.1 & 63.5 & 64.7 & 35.9 & 0.4 & -0.5 & 1.3 \\
\hline
\end{tabular}

Centres missing from the table were excluded from analysis due to low patient numbers or poor data completeness

*Salford and Manchester RI have been involved in the SPIRiT study; an RCT comparing low phosphate control (0.8 to $1.4 \mathrm{mmol} / \mathrm{L})$ with high phosphate group control (1.8 to $2.4 \mathrm{mmol} / \mathrm{L})$; HD patients only were recruited

phosphate in 2015. The overall data completeness for serum phosphate across the UK was $98.0 \%$ for $\mathrm{HD}$ and $98.8 \%$ for PD patients, with some variation between centres (tables 8.3, 8.5). HD centre returns were all $>90 \%$, except Cambridge and Sunderland at $0 \%$. For $\mathrm{PD}$ patients, Cambridge also returned no data and only one other centre (London West) returned less than $90 \%$ data, compared with five centres last year. Data completeness for serum phosphate has improved over the last decade, especially for HD patients from $73.2 \%$ to $98.0 \%$ but also for PD patients from $90.0 \%$ to $98.8 \%$.

The individual centre means and standard deviations are shown in tables 8.3 and 8.5 for $\mathrm{HD}$ and PD patients respectively.

For those receiving HD, $64.1 \%$ of patients achieved a phosphate level below $1.7 \mathrm{mmol} / \mathrm{L}$, the audit measure specified by the RA, and for those on PD this was $60.5 \%$ (tables $8.4,8.6$ ).
There was inter-centre and inter-modality variation in the proportion of patients below and equal to or above the phosphate target specified by the clinical performance audit measure (figures 8.1-8.4, tables 8.4, 8.6).

Funnel plots for HD patients with controlled phosphataemia $(<1.7 \mathrm{mmol} / \mathrm{L})$, show a number of centres attaining this standard in a significantly high proportion of patients: London West, Birmingham QEH, London Kings, Nottingham, Dorset, Wrexham, York and Liverpool Aintree. All these centres achieved above the 99.9\% upper confidence interval following correction for centre size. In addition, a number of centres had achieved the serum phosphate control standard in a lower than expected proportion of patients (being below the lower 99.9\% confidence interval): Portsmouth, Glasgow, Kent, Edinburgh and Dundee (figure 8.2).

Funnel plots for PD patients indicated that the control of phosphate levels were similar in all centres. No significant outliers were identified (figure 8.4). 
Table 8.5. Summary statistics for phosphate in peritoneal dialysis patients in 2015

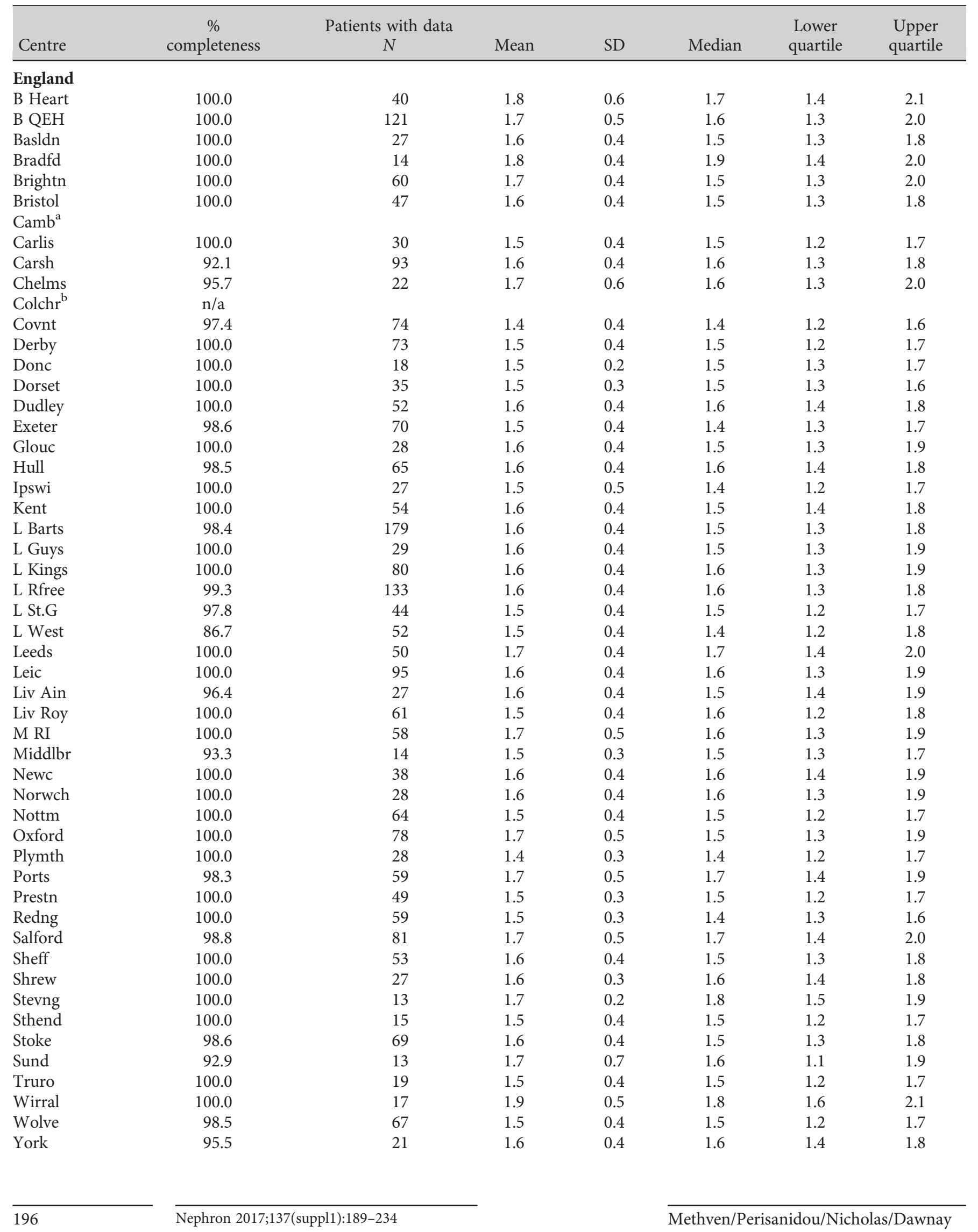


Table 8.5. Continued

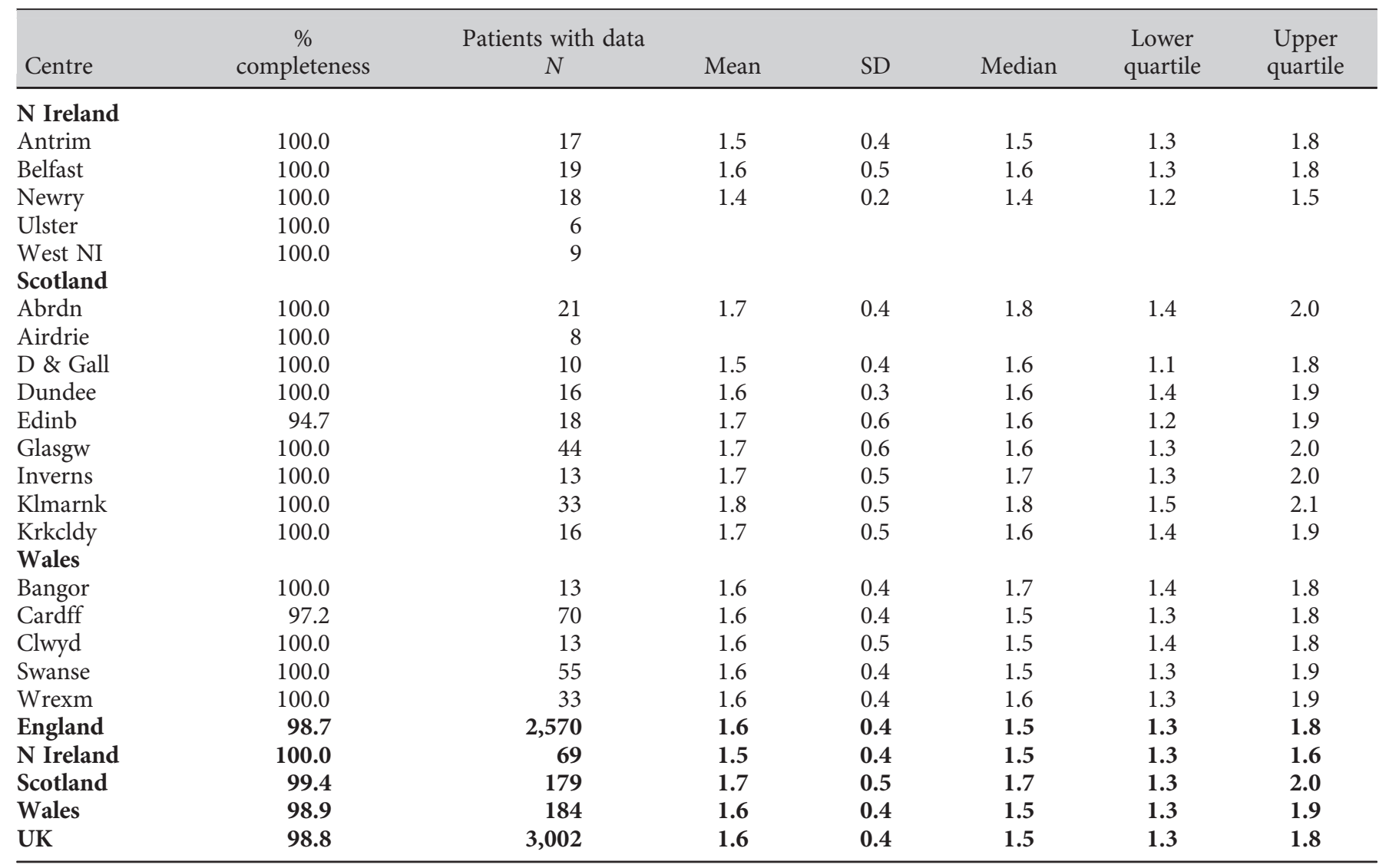

Blank cells: centres excluded from analysis due to low patient numbers or poor data completeness

${ }^{a}$ Cambridge renal centre was unable to submit serum phosphate data for 2015

b $/ \mathrm{a}$ - no PD patients

Table 8.6. Percentage of peritoneal dialysis patients with serum phosphate below and equal to or above $1.7 \mathrm{mmol} / \mathrm{L}$ as specified in the RA audit measure in 2015

\begin{tabular}{|c|c|c|c|c|c|c|c|c|}
\hline Centre & $N$ & $\begin{array}{c}\text { \% phos } \\
<1.7 \mathrm{mmol} / \mathrm{L}\end{array}$ & $\begin{array}{c}\text { Lower } 95 \% \\
\text { CI }\end{array}$ & $\begin{array}{c}\text { Upper } 95 \% \\
\text { CI }\end{array}$ & $\begin{array}{l}\text { \% with phos } \\
\geqslant 1.7 \mathrm{mmol} / \mathrm{L}\end{array}$ & $\begin{array}{l}\text { Change in \% } \\
<1.7 \mathrm{mmol} / \mathrm{L} \\
\text { from } 2014\end{array}$ & $\begin{array}{l}95 \% \text { LCL } \\
\text { change }\end{array}$ & $\begin{array}{l}95 \% \text { UCL } \\
\text { change }\end{array}$ \\
\hline \multicolumn{9}{|l|}{ England } \\
\hline B Heart & 40 & 50.0 & 35.0 & 65.0 & 50.0 & -6.3 & -29.4 & 16.9 \\
\hline B QEH & 121 & 58.7 & 49.7 & 67.1 & 41.3 & -5.1 & -17.5 & 7.3 \\
\hline Basldn & 27 & 51.9 & 33.6 & 69.6 & 48.2 & -0.1 & -27.3 & 27.0 \\
\hline Bradfd & 14 & 35.7 & 15.7 & 62.4 & 64.3 & -8.0 & -43.0 & 26.9 \\
\hline Brightn & 60 & 65.0 & 52.2 & 75.9 & 35.0 & -1.7 & -19.1 & 15.8 \\
\hline Bristol & 47 & 61.7 & 47.2 & 74.4 & 38.3 & 19.9 & 0.8 & 38.9 \\
\hline Carlis & 30 & 56.7 & 38.8 & 72.9 & 43.3 & 2.1 & -25.2 & 29.5 \\
\hline Carsh & 93 & 59.1 & 48.9 & 68.6 & 40.9 & -3.9 & -17.4 & 9.5 \\
\hline Chelms & 22 & 54.6 & 34.1 & 73.5 & 45.5 & 10.1 & -20.9 & 41.1 \\
\hline Covnt & 74 & 77.0 & 66.1 & 85.2 & 23.0 & 4.9 & -8.9 & 18.6 \\
\hline Derby & 73 & 69.9 & 58.4 & 79.3 & 30.1 & 5.6 & -9.8 & 21.0 \\
\hline Donc & 18 & 66.7 & 42.9 & 84.2 & 33.3 & 4.2 & -25.0 & 33.3 \\
\hline Dorset & 35 & 77.1 & 60.5 & 88.1 & 22.9 & 7.6 & -11.7 & 26.8 \\
\hline Dudley & 52 & 61.5 & 47.8 & 73.7 & 38.5 & 25.5 & 6.8 & 44.3 \\
\hline Exeter & 70 & 70.0 & 58.3 & 79.6 & 30.0 & 3.7 & -11.1 & 18.5 \\
\hline Glouc & 28 & 57.1 & 38.7 & 73.8 & 42.9 & 8.5 & -15.9 & 32.9 \\
\hline Hull & 65 & 55.4 & 43.2 & 66.9 & 44.6 & -8.3 & -25.0 & 8.5 \\
\hline
\end{tabular}


Table 8.6. Continued

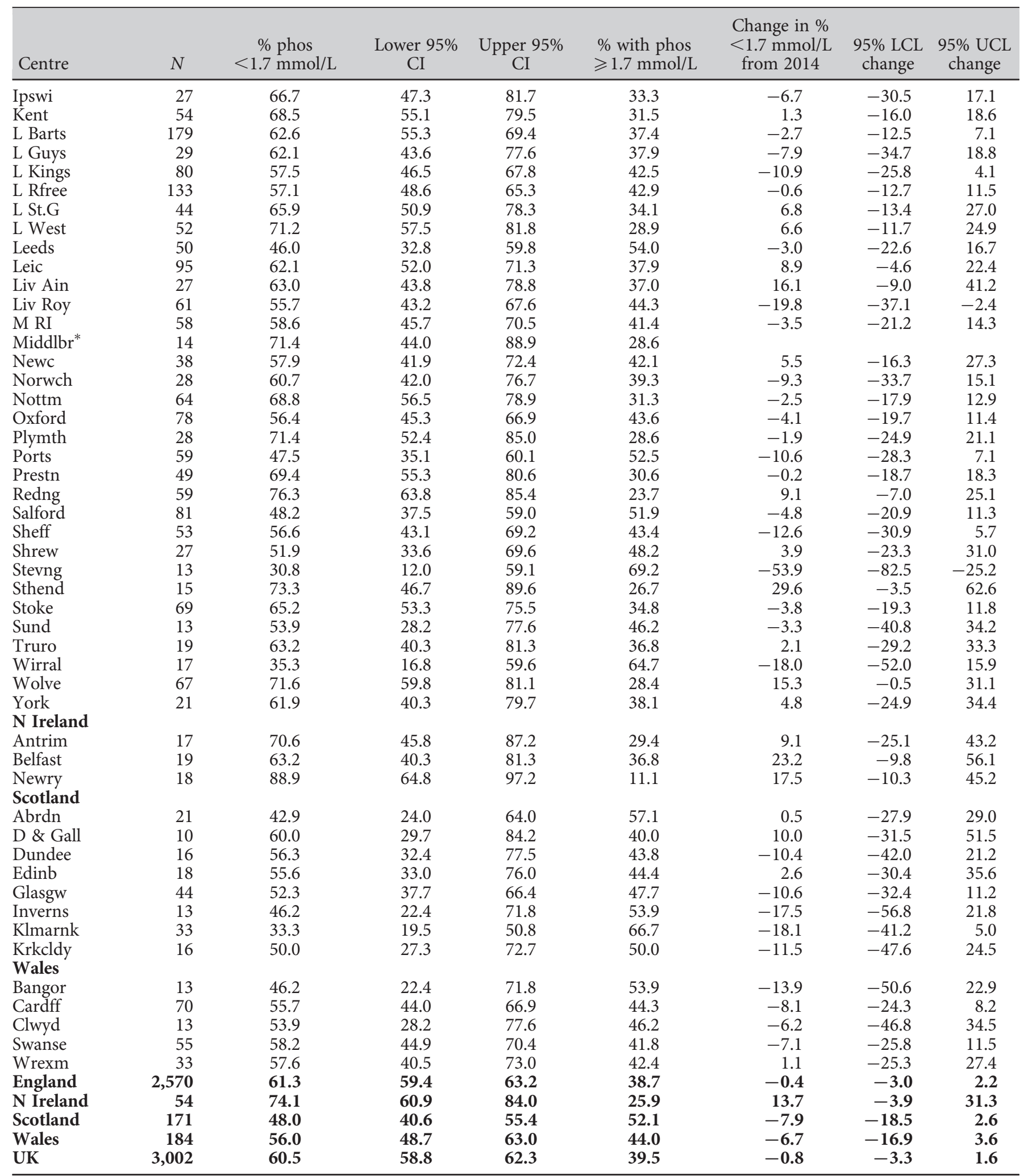

Centres missing from the table were excluded from analysis due to low patient numbers or poor data completeness *Bank cells indicate no data for 2014 


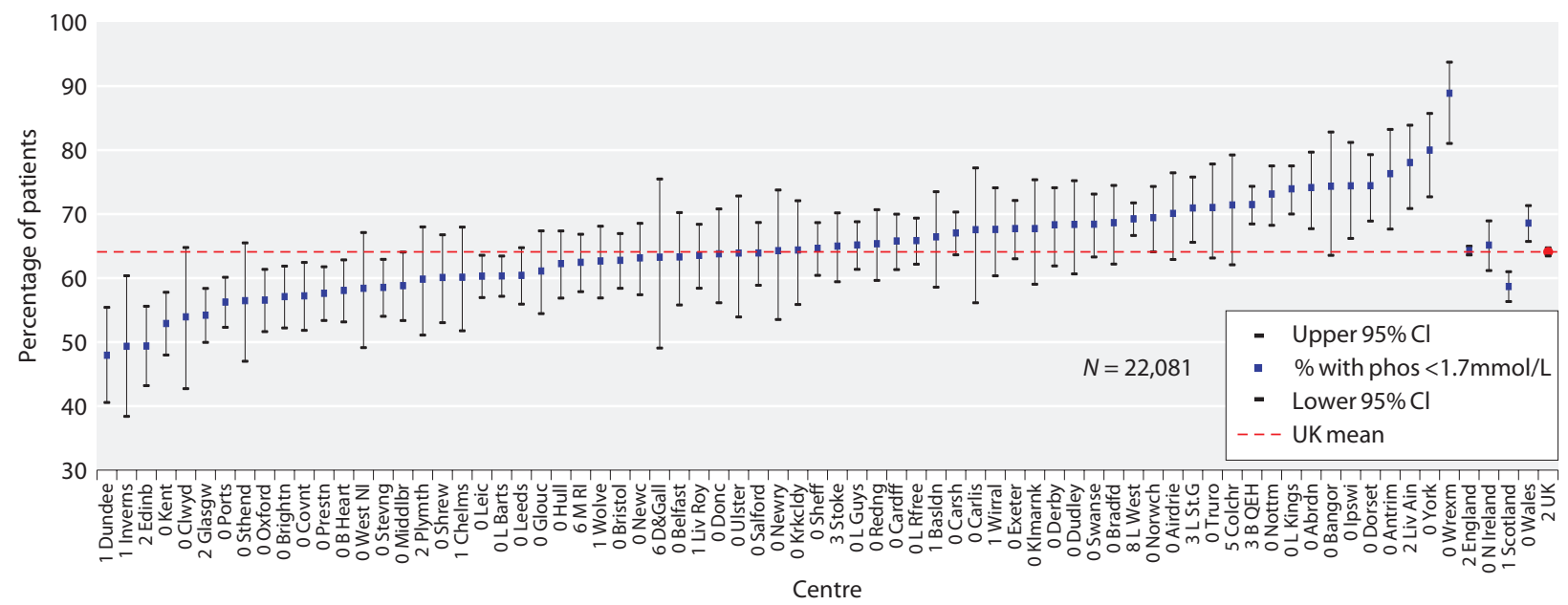

Fig. 8.1. Percentage of haemodialysis patients with serum phosphate below $1.7 \mathrm{mmol} / \mathrm{L}$ as specified by the RA audit measure, by centre in 2015

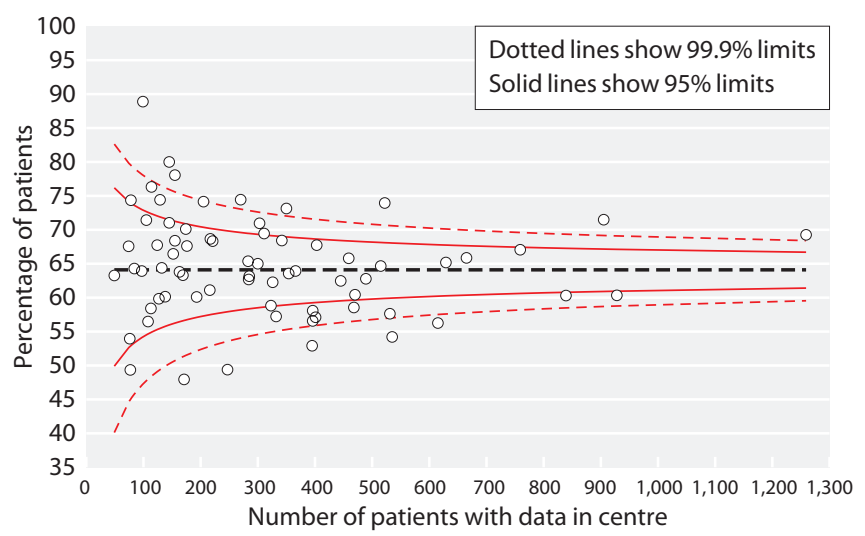

Fig. 8.2. Funnel plot of percentage of haemodialysis patients with serum phosphate below $1.7 \mathrm{mmol} / \mathrm{L}$ as specified by the RA clinical audit measure, by centre in 2015

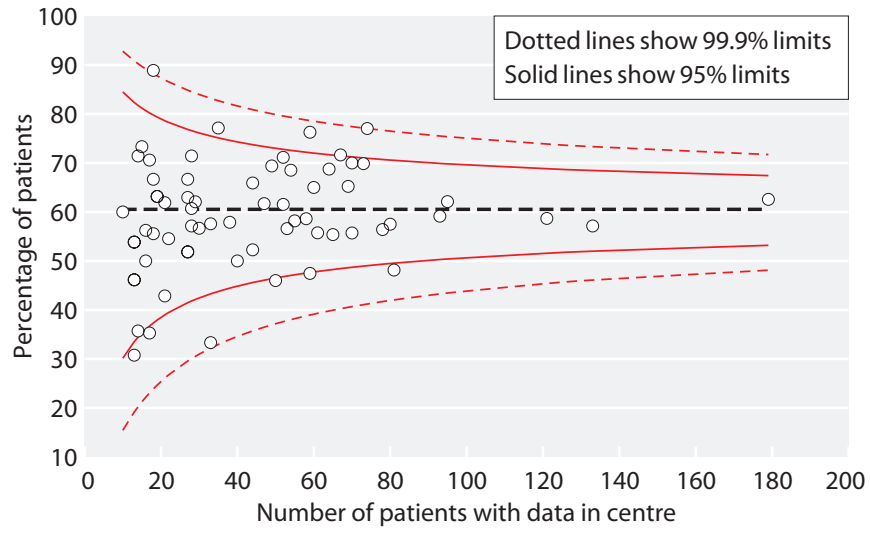

Fig. 8.4. Funnel plot of percentage of peritoneal dialysis patients with phosphate below $1.7 \mathrm{mmol} / \mathrm{L}$ as specified by the RA clinical audit measure, by centre in 2015

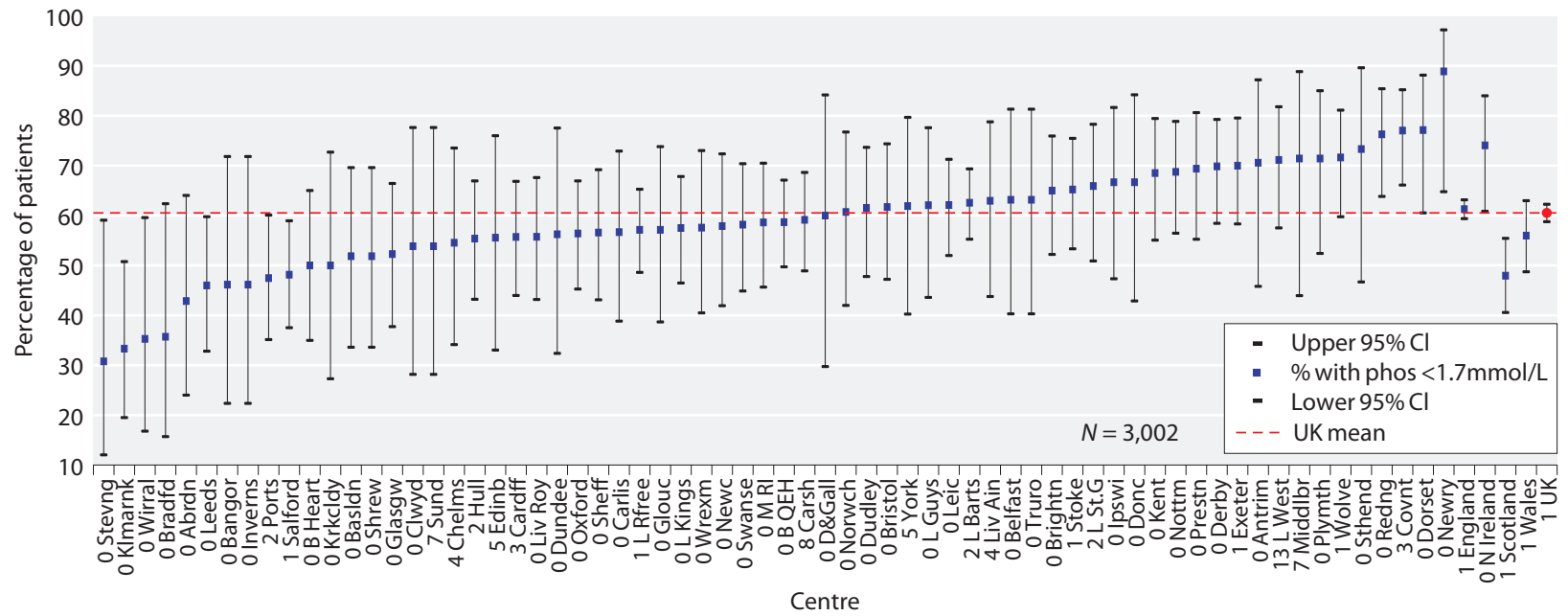

Fig. 8.3. Percentage of peritoneal dialysis patients with serum phosphate below $1.7 \mathrm{mmol} / \mathrm{L}$ as specified by the RA audit measure, by centre in 2015 


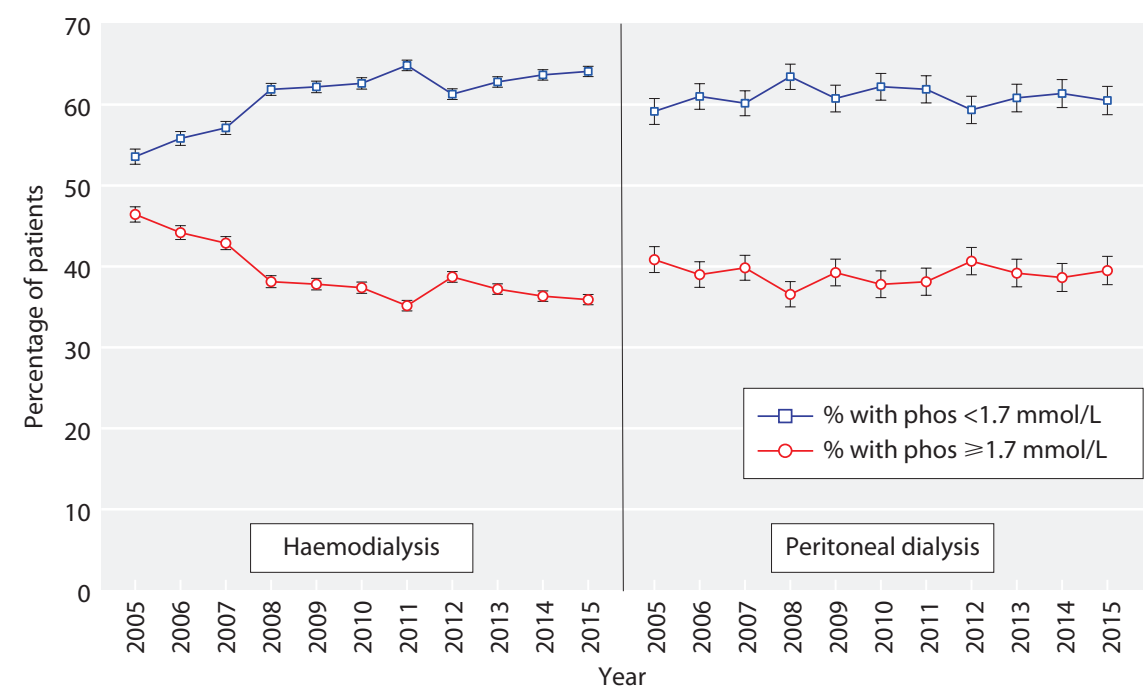

Fig. 8.5. Longitudinal change in percentage of patients with phosphate below and equal to or above $1.7 \mathrm{mmol} / \mathrm{L}$, as specified by the RA clinical audit measure, by dialysis modality 2005-2015
The audit measure of phosphate $<1.7 \mathrm{mmol} / \mathrm{L}$ is new in the updated 2015 clinical practice guideline [3] and comparable data for previous years have been calculated for comparison purposes. Longitudinal analysis demonstrated a small but continued improvement against the clinical performance measure for those receiving HD whilst the proportion of PD patients with hyperphosphataemia has remained stable (figure 8.5). Data showing the performance of centres in attaining phosphate control within the guideline target range $(1.1-1.7 \mathrm{mmol} / \mathrm{L}) \mathrm{can}$ be found in appendix 1 of this chapter (rather than the audit measure of $<1.7 \mathrm{mmol} / \mathrm{L}$ presented here).

Simultaneous control of adjusted calcium, phosphate and PTH in preventing severe hyperparathyroidism

At the beginning of 2015 the following RA audit measure for combined biochemical control applied:

'Percentage of patients with all bone parameters within target range (Calcium/Phosphate/PTH)'
The RA guideline does not explicitly outline the target ranges to be used in the audit measure itself therefore the authors have interpreted this to include the target ranges suggested for each biochemical measure in the guideline. Therefore the combined audit measure comprised the following: phosphate $1.1-1.7 \mathrm{mmol} / \mathrm{L}$, adjusted calcium 2.2-2.5 mmol/L and PTH $16-72 \mathrm{pmol} / \mathrm{L}$. Please note this phosphate measure is discrepant with the preceding audit measure for phosphate alone (of $<1.7 \mathrm{mmol} / \mathrm{L}$ ). This section presents only the audit measure of composite control, however data regarding attainment of each of the three components individually can be found in appendix 1 .

There were combined biochemical results to assess mineral bone disease available from $57 \mathrm{HD}$ and $52 \mathrm{PD}$ centres, including $17,811 \mathrm{HD}$ and 2,336 PD patients, from England, Wales and Northern Ireland in 2015. Table 8.7 demonstrates the percentage of patients achieving results within the target range for none, one, two or all three bone mineral parameters, by centre for patients

Table 8.7. Percentage of haemodialysis patients achieving simultaneous control of the three key bone and mineral disorder parameters (adjusted calcium, phosphate and parathyroid hormone) by centre, in 2015

\begin{tabular}{lrrrrr} 
& & & \multicolumn{2}{c}{ Number of parameters } \\
\cline { 3 - 6 } Centre & $N$ & None & One & Two & \\
\hline England & & & & & \\
B Heart & 393 & 7.4 & 21.1 & 40.5 & 31.0 \\
Basldn & 150 & 2.7 & 26.0 & 45.3 & 26.0 \\
Bradfd & 213 & 2.3 & 24.4 & 50.5 & 28.6 \\
Brightn & 394 & 3.6 & 22.1 & 43.3 & 23.9 \\
Bristol & 485 & 2.1 & 22.1 & 43.1 & 32.6 \\
Carlis & 72 & 4.2 & 31.9 & 40.6 & 20.8 \\
Carsh & 731 & 5.3 & 27.1 & 42.8 & 26.9 \\
Chelms & 138 & 2.9 & 27.5 & & 26.8
\end{tabular}


Table 8.7. Continued

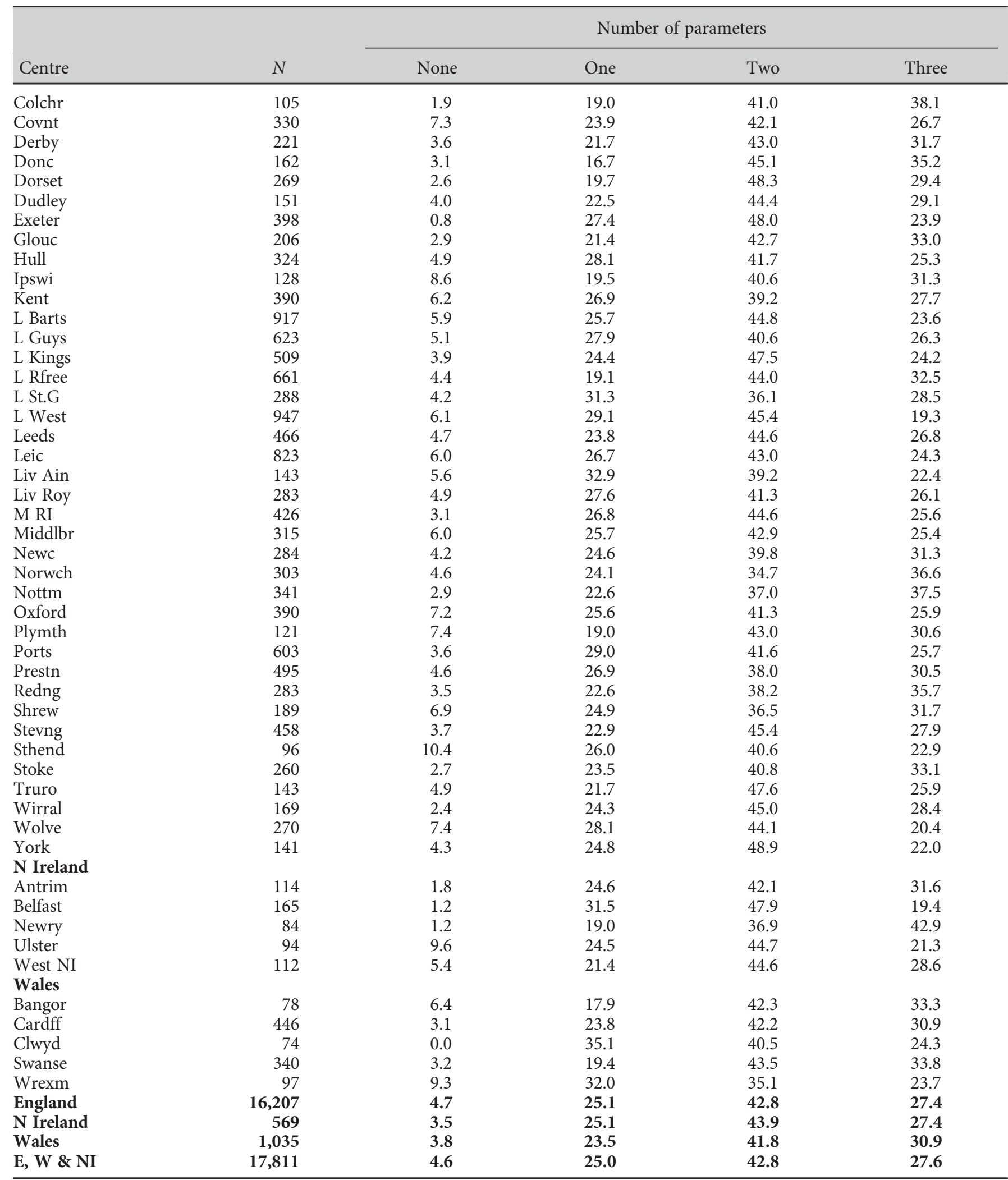

Centres excluded if they did not have at least $50 \%$ completeness for all of the three variables 
Table 8.8. Percentage of peritoneal dialysis patients achieving simultaneous control of the three key bone and mineral disorder parameters (adjusted calcium, phosphate and parathyroid hormone) by centre, in 2015

\begin{tabular}{|c|c|c|c|c|c|}
\hline \multirow[b]{2}{*}{ Centre } & \multirow[b]{2}{*}{$N$} & \multicolumn{4}{|c|}{ Number of parameters } \\
\hline & & None & One & Two & Three \\
\hline \multicolumn{6}{|l|}{ England } \\
\hline B Heart & 37 & 10.8 & 18.9 & 45.9 & 24.3 \\
\hline Basldn & 27 & 3.7 & 18.5 & 37.0 & 40.7 \\
\hline Bradfd & 13 & 7.7 & 23.1 & 38.5 & 30.8 \\
\hline Carlis & 27 & 0.0 & 11.1 & 48.1 & 40.7 \\
\hline Carsh & 83 & 7.2 & 19.3 & 49.4 & 24.1 \\
\hline Chelms & 20 & 15.0 & 35.0 & 20.0 & 30.0 \\
\hline Covnt & 69 & 4.3 & 21.7 & 47.8 & 26.1 \\
\hline Derby & 68 & 1.5 & 17.6 & 44.1 & 36.8 \\
\hline Glouc & 24 & 0.0 & 16.7 & 54.2 & 29.2 \\
\hline Hull & 54 & 7.4 & 27.8 & 35.2 & 29.6 \\
\hline Ipswi & 27 & 14.8 & 11.1 & 51.9 & 22.2 \\
\hline Kent & 54 & 9.3 & 20.4 & 33.3 & 37.0 \\
\hline L Barts & 172 & 3.5 & 17.4 & 39.0 & 40.1 \\
\hline L Guys & 24 & 4.2 & 20.8 & 33.3 & 41.7 \\
\hline L Kings & 72 & 2.8 & 29.2 & 40.3 & 27.8 \\
\hline L Rfree & 123 & 4.1 & 21.1 & 38.2 & 36.6 \\
\hline L St.G & 44 & 6.8 & 29.5 & 40.9 & 22.7 \\
\hline L West & 45 & 11.1 & 20.0 & 37.8 & 31.1 \\
\hline Leeds & 50 & 0.0 & 18.0 & 48.0 & 34.0 \\
\hline Oxford & 77 & 1.3 & 11.7 & 49.4 & 37.7 \\
\hline Plymth & 26 & 3.8 & 26.9 & 38.5 & 30.8 \\
\hline Ports & 50 & 0.0 & 34.0 & 46.0 & 20.0 \\
\hline Prestn & 49 & 2.0 & 20.4 & 42.9 & 34.7 \\
\hline Redng & 55 & 0.0 & 12.7 & 36.4 & 50.9 \\
\hline Shrew & 26 & 3.8 & 15.4 & 34.6 & 46.2 \\
\hline Stevng & 11 & 9.1 & 18.2 & 54.5 & 18.2 \\
\hline Stoke & 57 & 5.3 & 17.5 & 47.4 & 29.8 \\
\hline Sund & 13 & 0.0 & 7.7 & 69.2 & 23.1 \\
\hline Truro & 18 & 0.0 & 16.7 & 50.0 & 33.3 \\
\hline Wirral & 16 & 6.3 & 6.3 & 68.8 & 18.8 \\
\hline Wolve & 65 & 4.6 & 24.6 & 33.8 & 36.9 \\
\hline York & 21 & 4.8 & 38.1 & 28.6 & 28.6 \\
\hline \multicolumn{6}{|c|}{ N Ireland } \\
\hline Antrim & 17 & 0.0 & 23.5 & 52.9 & 23.5 \\
\hline Belfast & 19 & 5.3 & 21.1 & 31.6 & 42.1 \\
\hline Newry & 18 & 0.0 & 22.2 & 44.4 & 33.3 \\
\hline
\end{tabular}


Table 8.8. Continued

\begin{tabular}{|c|c|c|c|c|c|}
\hline \multirow[b]{2}{*}{ Centre } & \multirow[b]{2}{*}{$N$} & \multicolumn{4}{|c|}{ Number of parameters } \\
\hline & & None & One & Two & Three \\
\hline \multicolumn{6}{|l|}{ Wales } \\
\hline Bangor & 13 & 0.0 & 38.5 & 30.8 & 30.8 \\
\hline Cardff & 61 & 3.3 & 29.5 & 41.0 & 26.2 \\
\hline Swanse & 53 & 3.8 & 17.0 & 50.9 & 28.3 \\
\hline Wrexm & 33 & 3.0 & 18.2 & 45.5 & 33.3 \\
\hline England & 2,122 & 4.3 & 20.5 & 41.8 & 33.4 \\
\hline N Ireland & 54 & 1.9 & 22.2 & 42.6 & 33.3 \\
\hline Wales & 160 & 3.1 & 23.8 & 44.4 & 28.8 \\
\hline E, W \& NI & 2,336 & 4.2 & 20.7 & 42.0 & 33.1 \\
\hline
\end{tabular}

Centres excluded if they did not have at least $50 \%$ completeness for all of the three variables

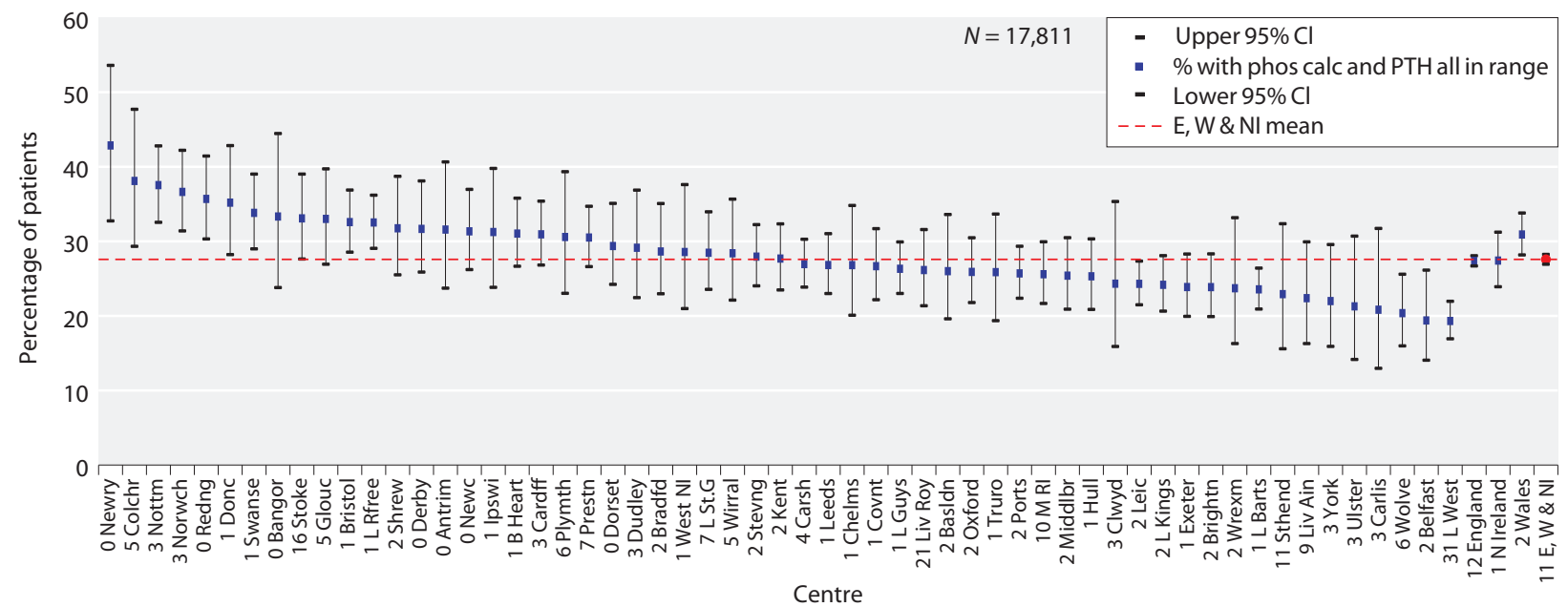

Fig. 8.6. Percentage of HD patients achieving simultaneous control of the three key mineral bone disorders (adjusted calcium, phosphate and parathyroid hormone) in preventing severe hyperparathyroidism, by centre in 2015

receiving $\mathrm{HD}$ and figure 8.6 shows the variation between centres in the proportion achieving control of all three parameters. Table 8.8 and figure 8.7 show the same data for patients receiving PD.

Overall, $4.6 \%$ of $\mathrm{HD}$ and $4.2 \%$ of PD patients across England, Wales and Northern Ireland had none of the three bone mineral parameters controlled within the target ranges described above. Control of one parameter was reported in $25.0 \%$ of $\mathrm{HD}$ and $20.7 \%$ of PD patients; of two parameters in $42.8 \%$ of $\mathrm{HD}$ and $42.0 \%$ of $\mathrm{PD}$ patients; of all three parameters in $27.6 \%$ of $\mathrm{HD}$ and $33.1 \%$ of PD patients (tables $8.7,8.8$ ).

Figures 8.8 and 8.9 are funnel plots showing the percentage with control of the three bone mineral parameters by centre (who contributed data to these analyses). There was little variation in the percentage achieving simultaneous control of the three bone mineral parameters for HD patients, with only one centre being above the 99.9\% confidence interval and one below. There was even less variation for PD centres with one centre above and none below the $99.9 \%$ confidence interval.

\section{Bicarbonate}

In 2015 the following Renal Association clinical practice guidelines regarding bicarbonate management were applicable:

Haemodialysis Guideline 6.3: Pre-dialysis serum bicarbonate concentrations

'We suggest that pre-dialysis serum bicarbonate concentrations, measured with minimum delay after venepuncture, should be between 18 and $24 \mathrm{mmol} / \mathrm{L}^{\prime}$ [7]. 


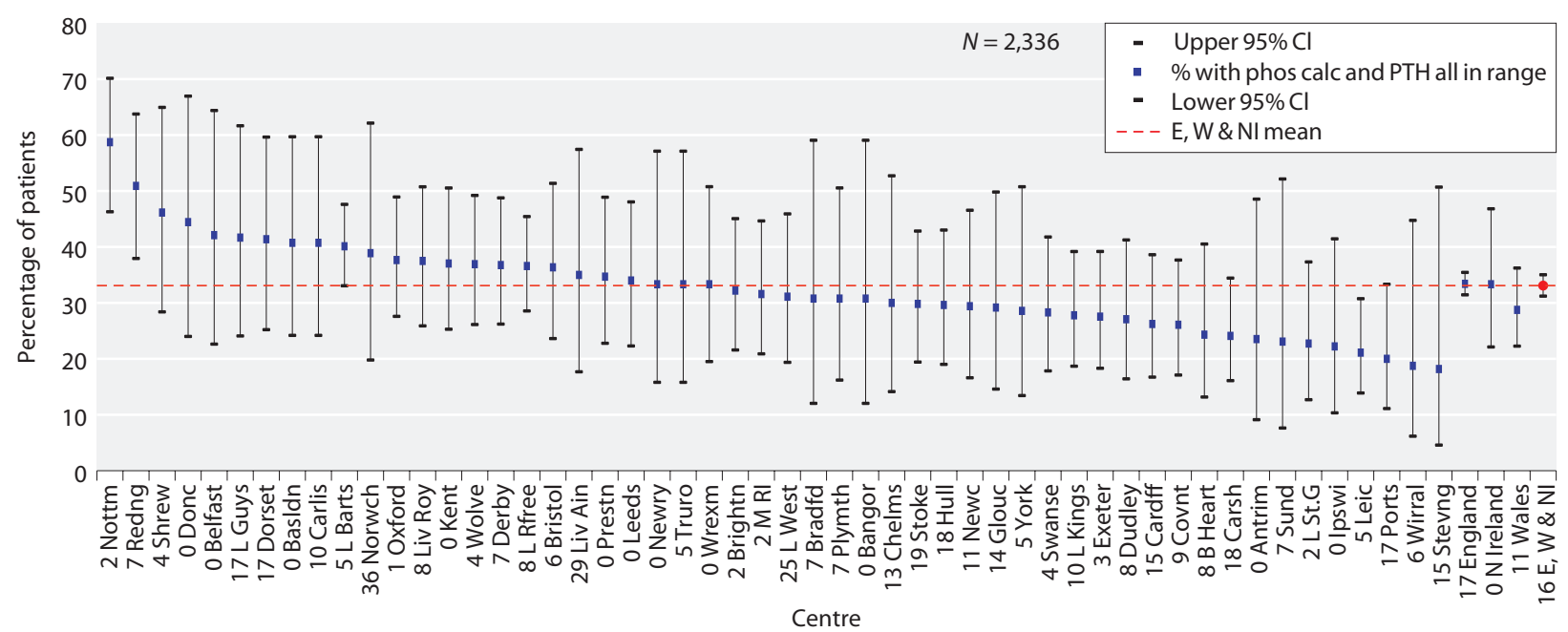

Fig. 8.7. Percentage of PD patients achieving simultaneous control of all three mineral bone disorders (adjusted calcium, phosphate and parathyroid hormone) in preventing severe hyperparathyroidism, by centre in 2015

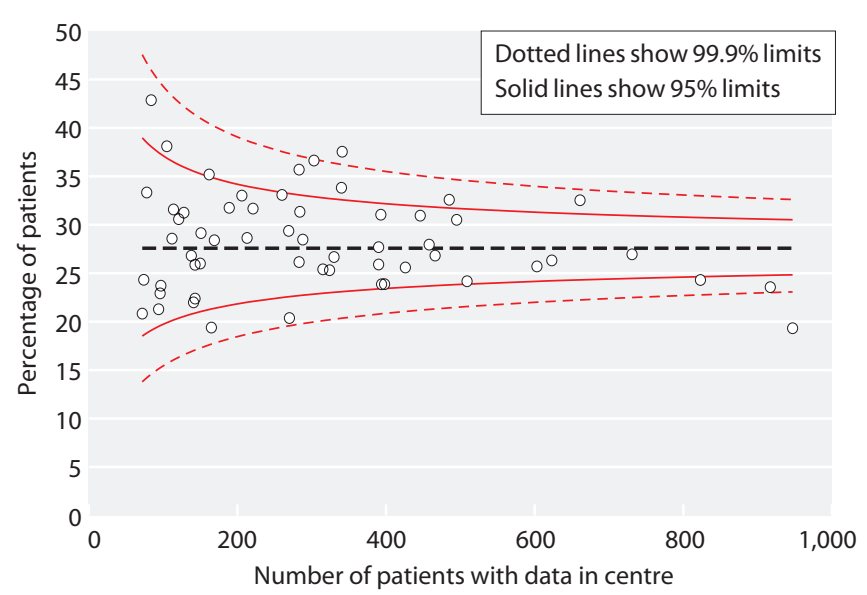

Fig. 8.8. Funnel plot of percentage of HD patients achieving simultaneous control of all three mineral bone disorders (adjusted calcium, phosphate and parathyroid hormone) in preventing severe hyperparathyroidism, by centre in 2015

\section{Peritoneal Dialysis Guideline 6.2 - PD: Metabolic factors}

'We recommend that plasma bicarbonate should be maintained within the normal range' [8].

A total of 19,253 HD and 2,560 PD patients' data were available for serum bicarbonate analysis from England, Wales and Northern Ireland in 2015. Data were 92.6\% complete for HD patients and $89.5 \%$ complete for PD patients (tables 8.9, 8.11). Data completeness for serum bicarbonate levels in HD and PD patients has not changed significantly over a decade. The proportion of HD patients with serum bicarbonate within the audit measure

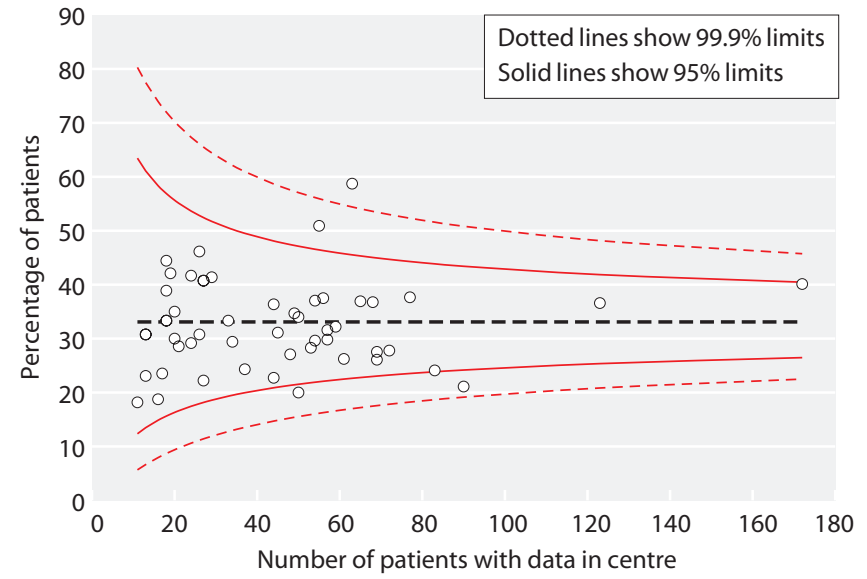

Fig. 8.9. Funnel plot of percentage of PD patients achieving simultaneous control of all three mineral bone disorders (adjusted calcium, phosphate and parathyroid hormone) in preventing severe hyperparathyroidism, by centre in 2015

range was $64.3 \%$ in 2015 (95\% CI $63.7-65.0 \%)$ (table 8.10); the mean bicarbonate in HD patients was $23.2 \mathrm{mmol} / \mathrm{L}$ (table 8.9). The proportion with a serum bicarbonate within the audit standard in PD patients was $80.4 \%$ (CI 78.8-81.9\%) (table 8.12). The mean bicarbonate level in PD patients was $24.8 \mathrm{mmol} / \mathrm{L}$ (table 8.11).

As in previous reports, inter-centre variation was observed in attainment of the audit standard (tables 8.10, 8.12 , figures $8.10-8.13$ ). The funnel plot of serum bicarbonate values in 2015 for HD patients (figure 8.11) showed a large dispersal of attainment, 22 centres being above the $99.9 \%$ limit and 13 below the $99.9 \%$ limit. In contrast, the funnel plot for PD patients (figure 8.13) showed few outliers. Sample processing, case-mix, 
Table 8.9. Summary statistics for serum bicarbonate in haemodialysis patients by centre in 2015

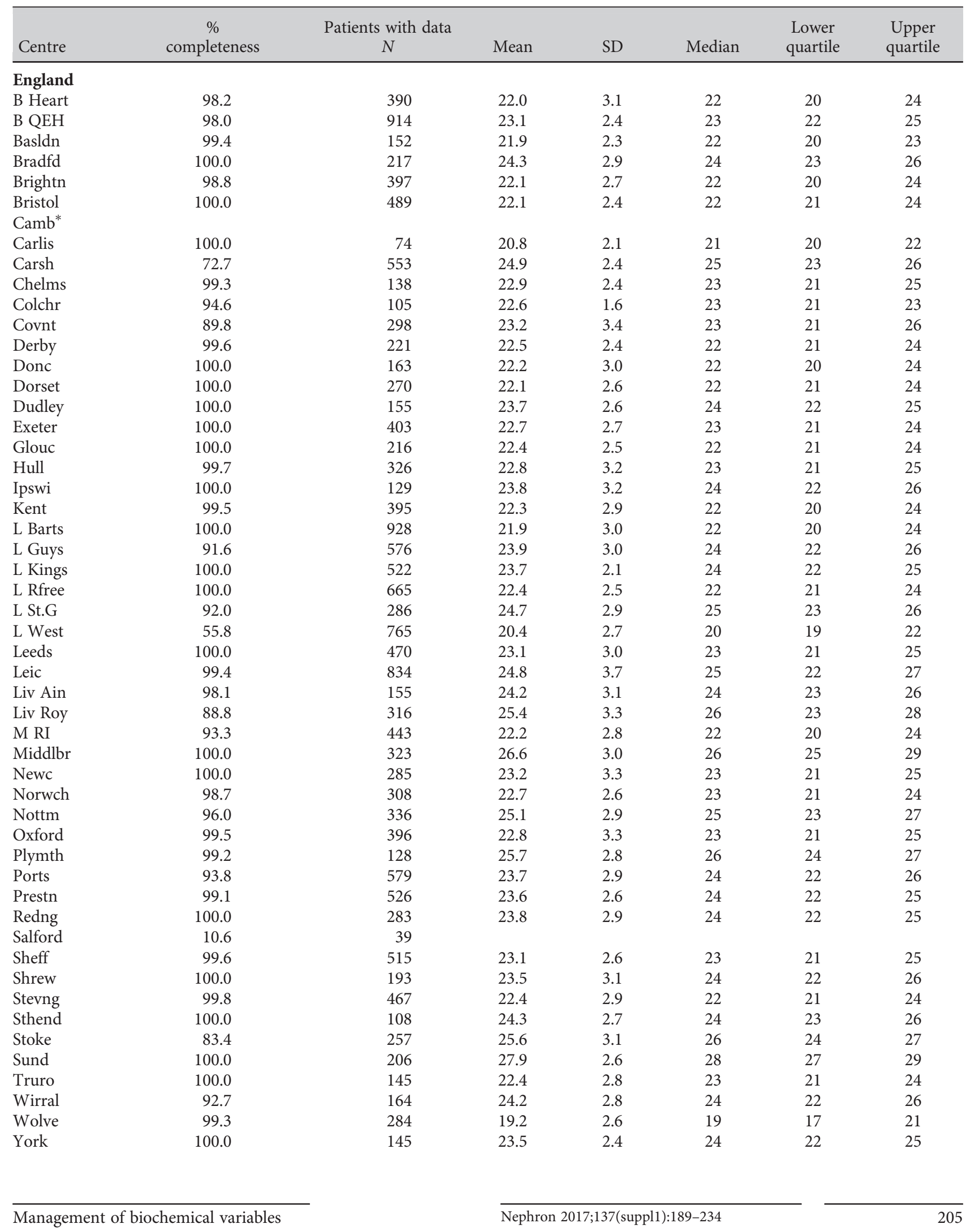


Table 8.9. Continued

\begin{tabular}{|c|c|c|c|c|c|c|c|}
\hline Centre & $\begin{array}{c}\% \\
\text { completeness }\end{array}$ & $\begin{array}{c}\text { Patients with data } \\
\qquad N\end{array}$ & Mean & $\mathrm{SD}$ & Median & $\begin{array}{l}\text { Lower } \\
\text { quartile }\end{array}$ & $\begin{array}{l}\text { Upper } \\
\text { quartile }\end{array}$ \\
\hline \multicolumn{8}{|l|}{ N Ireland } \\
\hline Belfast & 100.0 & 169 & 21.9 & 2.9 & 22 & 20 & 24 \\
\hline Newry & 100.0 & 84 & 23.1 & 2.2 & 23 & 22 & 25 \\
\hline Ulster & 100.0 & 97 & 22.4 & 2.5 & 23 & 21 & 24 \\
\hline \multicolumn{8}{|l|}{ Wales } \\
\hline Bangor & 100.0 & 78 & 24.0 & 2.8 & 24 & 22 & 26 \\
\hline Cardff & 93.3 & 429 & 23.5 & 2.8 & 24 & 22 & 25 \\
\hline Clwyd & 100.0 & 76 & 23.4 & 2.8 & 23 & 21 & 25 \\
\hline Swanse & 100.0 & 342 & 23.5 & 2.6 & 23 & 22 & 25 \\
\hline Wrexm & 100.0 & 99 & 26.0 & 2.1 & 26 & 25 & 27 \\
\hline
\end{tabular}

Blank cells: centres excluded from analysis due to low patient numbers or poor data completeness

* Cambridge renal centre was unable to submit bicarbonate data for 2015

Table 8.10. Percentage of haemodialysis patients within, below and above the range for bicarbonate $(18-24 \mathrm{mmol} / \mathrm{L})$ by centre in 2015

\begin{tabular}{|c|c|c|c|c|c|c|c|c|c|}
\hline Centre & $N$ & $\begin{array}{c}\% \text { bicarb } \\
18-24 \mathrm{mmol} / \mathrm{L}\end{array}$ & $\begin{array}{l}\text { Lower } \\
95 \% \mathrm{CI}\end{array}$ & $\begin{array}{l}\text { Upper } \\
95 \% \text { CI }\end{array}$ & $\begin{array}{c}\% \text { bicarb } \\
<18 \mathrm{mmol} / \mathrm{L}\end{array}$ & $\begin{array}{c}\% \text { bicarb } \\
>24 \mathrm{mmol} / \mathrm{L}\end{array}$ & $\begin{array}{l}\text { Change in \% } \\
\text { within range } \\
\text { from } 2014\end{array}$ & $\begin{array}{c}\text { 95\% } \\
\text { LCL } \\
\text { change }\end{array}$ & $\begin{array}{c}95 \% \\
\text { UCL } \\
\text { change }\end{array}$ \\
\hline \multicolumn{10}{|l|}{ England } \\
\hline B Heart & 390 & 78.5 & 74.1 & 82.3 & 5.4 & 16.2 & 3.1 & -2.8 & 9.0 \\
\hline B QEH & 914 & 70.6 & 67.5 & 73.4 & 1.4 & 28.0 & 8.0 & 3.7 & 12.4 \\
\hline Basldn & 152 & 86.2 & 79.7 & 90.8 & 2.6 & 11.2 & 8.6 & 0.1 & 17.2 \\
\hline Bradfd & 217 & 50.7 & 44.1 & 57.3 & 1.4 & 47.9 & -3.4 & -13.0 & 6.2 \\
\hline Brightn & 397 & 78.3 & 74.0 & 82.1 & 4.3 & 17.4 & 1.5 & -4.3 & 7.3 \\
\hline Bristol & 489 & 85.1 & 81.6 & 88.0 & 2.5 & 12.5 & 6.3 & 1.5 & 11.1 \\
\hline Carlis & 74 & 90.5 & 81.5 & 95.4 & 6.8 & 2.7 & -2.9 & -12.0 & 6.2 \\
\hline Carsh & 553 & 43.0 & 39.0 & 47.2 & 0.2 & 56.8 & 5.1 & -1.2 & 11.3 \\
\hline Chelms & 138 & 72.5 & 64.4 & 79.3 & 1.5 & 26.1 & -15.8 & -25.1 & -6.5 \\
\hline Colchr & 105 & 85.7 & 77.7 & 91.2 & 0.0 & 14.3 & 15.2 & 4.2 & 26.2 \\
\hline Covnt & 298 & 61.7 & 56.1 & 67.1 & 3.4 & 34.9 & 7.1 & -0.9 & 15.0 \\
\hline Derby & 221 & 79.6 & 73.8 & 84.4 & 2.7 & 17.7 & 5.5 & -2.4 & 13.3 \\
\hline Donc & 163 & 75.5 & 68.3 & 81.5 & 2.5 & 22.1 & 3.2 & -6.3 & 12.7 \\
\hline Dorset & 270 & 82.6 & 77.6 & 86.7 & 3.0 & 14.4 & 1.4 & -5.2 & 7.9 \\
\hline Dudley & 155 & 60.7 & 52.8 & 68.0 & 0.7 & 38.7 & 3.1 & -7.8 & 13.9 \\
\hline Exeter & 403 & 74.9 & 70.5 & 78.9 & 2.5 & 22.6 & 15.8 & 9.3 & 22.3 \\
\hline Glouc & 216 & 77.3 & 71.3 & 82.4 & 3.7 & 19.0 & 24.4 & 15.6 & 33.2 \\
\hline Hull & 326 & 65.0 & 59.7 & 70.0 & 6.4 & 28.5 & 4.2 & -3.3 & 11.8 \\
\hline Ipswi & 129 & 54.3 & 45.6 & 62.7 & 2.3 & 43.4 & -3.5 & -15.9 & 8.9 \\
\hline
\end{tabular}


Table 8.10. Continued

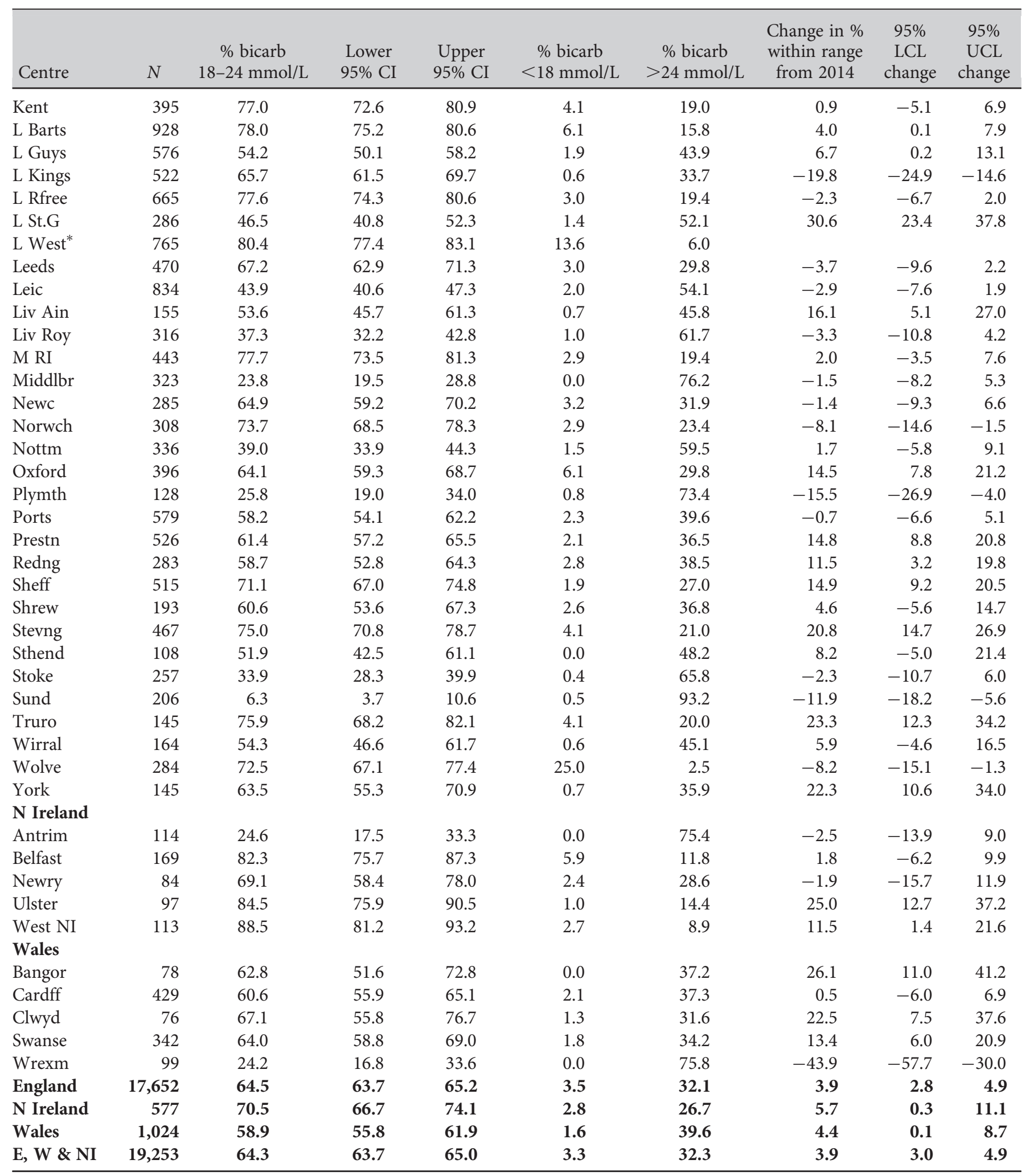

Centres missing from the table were excluded from analysis due to low patient numbers or poor data completeness *Blank cells indicate no data for 2014 


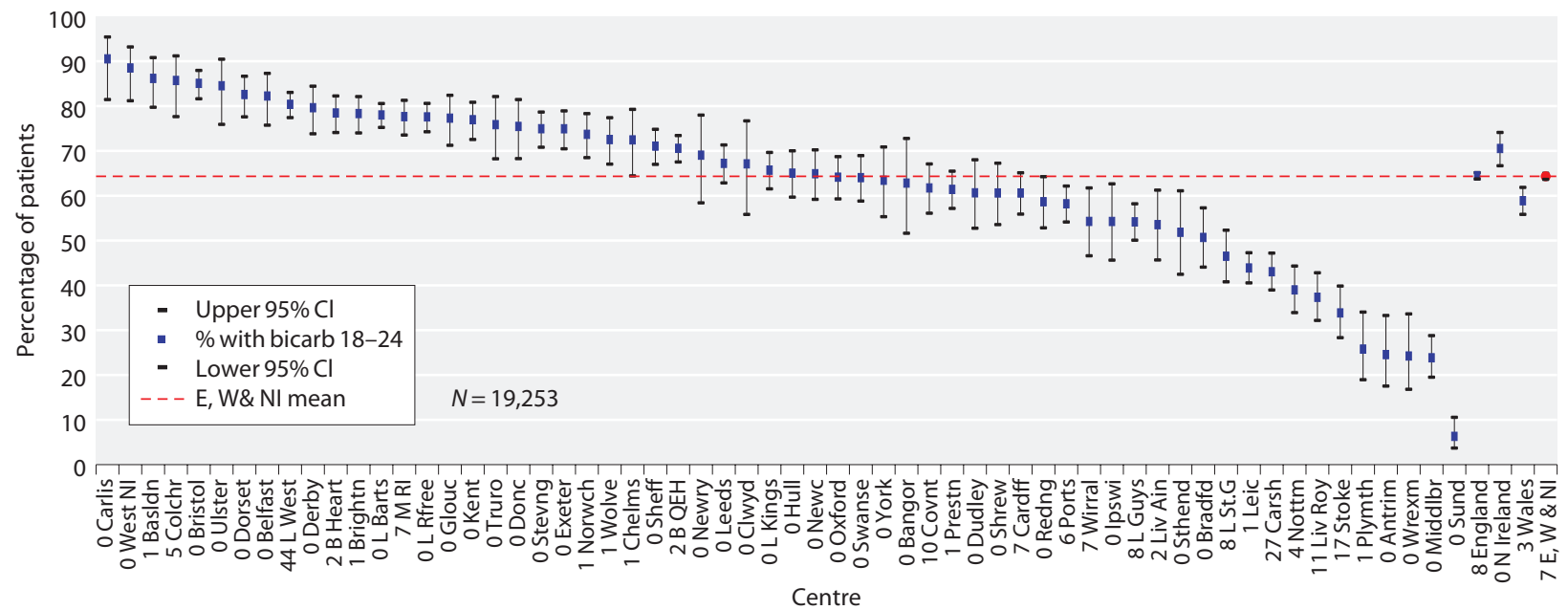

Fig. 8.10. Percentage of haemodialysis patients with serum bicarbonate within range ( $18-24 \mathrm{mmol} / \mathrm{L})$ by centre in 2015

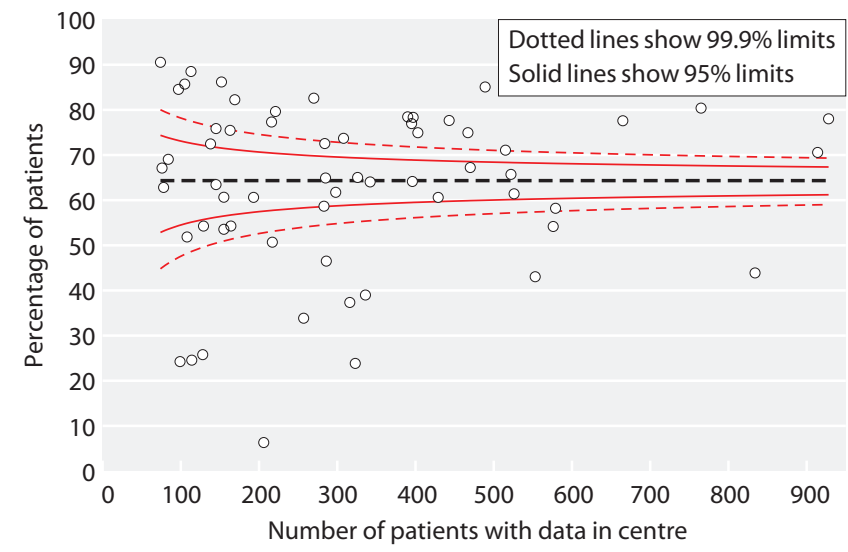

Fig. 8.11. Funnel plot for percentage of haemodialysis patients within range for bicarbonate $(18-24 \mathrm{mmol} / \mathrm{L})$ by centre in 2015

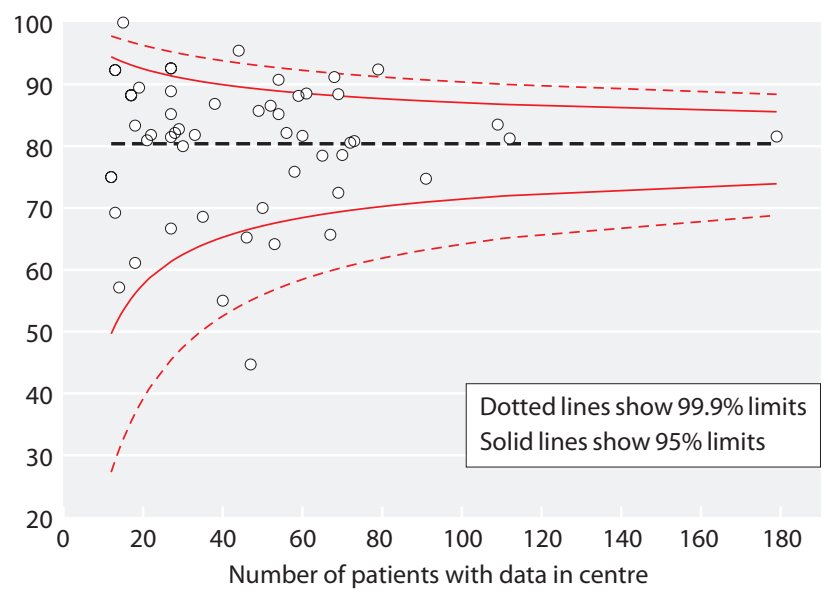

Fig. 8.13. Funnel plot for percentage of peritoneal dialysis patients within range for bicarbonate $(22-30 \mathrm{mmol} / \mathrm{L})$ by centre in 2015

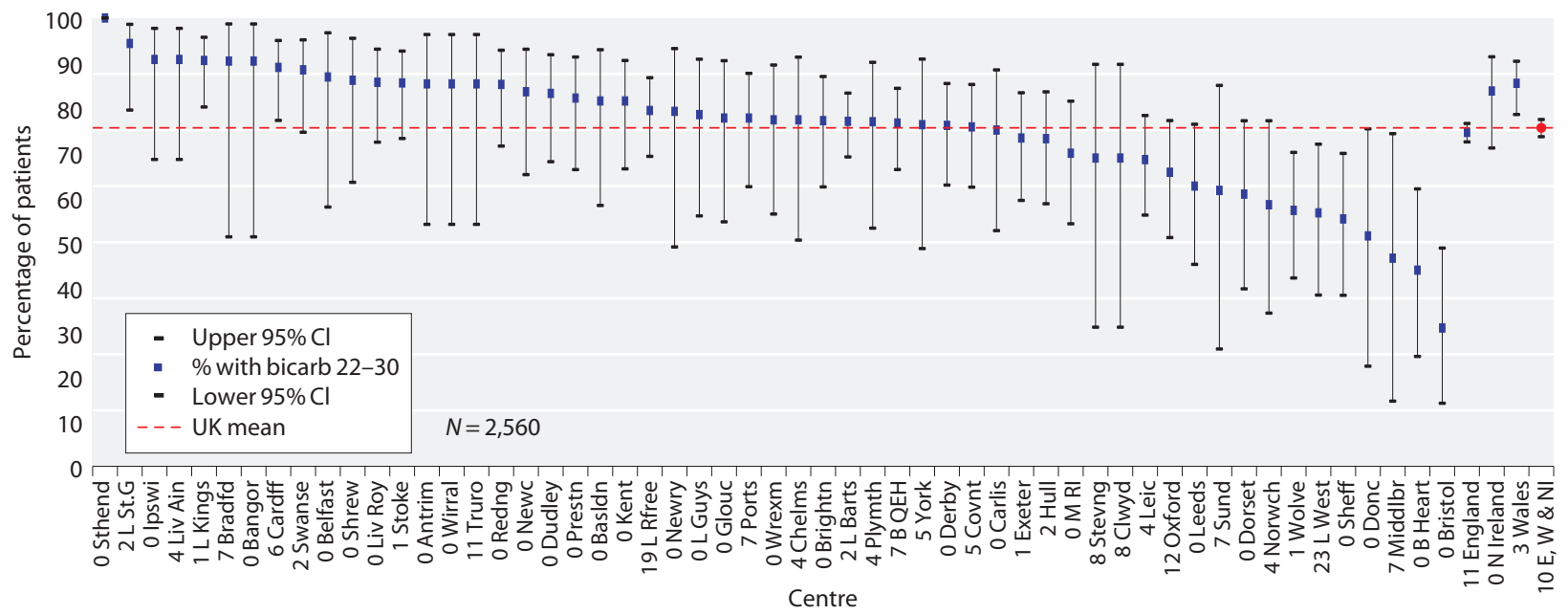

Fig. 8.12. Percentage of peritoneal dialysis patients with serum bicarbonate within range $(22-30 \mathrm{mmol} / \mathrm{L})$ by centre in 2015 
Table 8.11. Summary statistics for serum bicarbonate in peritoneal dialysis patients by centre in 2015

\begin{tabular}{|c|c|c|c|c|c|c|c|}
\hline Centre & $\begin{array}{c}\% \\
\text { completeness }\end{array}$ & $\begin{array}{c}\text { Patients with data } \\
\qquad N\end{array}$ & Mean & $\mathrm{SD}$ & Median & $\begin{array}{c}\text { Lower } \\
\text { quartile }\end{array}$ & $\begin{array}{l}\text { Upper } \\
\text { quartil }\end{array}$ \\
\hline \multicolumn{8}{|l|}{ England } \\
\hline B QEH & 92.6 & 112 & 23.6 & 2.7 & 24 & 22 & 25 \\
\hline Basldn & 100.0 & 27 & 25.2 & 3.1 & 25 & 23 & 27 \\
\hline Bradfd & 92.9 & 13 & 26.9 & 1.8 & 27 & 26 & 28 \\
\hline \multicolumn{8}{|l|}{$\mathrm{Camb}^{\mathrm{a}}$} \\
\hline Carlis & 100.0 & 30 & 24.3 & 2.7 & 24 & 22 & 27 \\
\hline Carsh & 0.0 & 0 & & & & & \\
\hline Chelms & 95.7 & 22 & 24.7 & 2.8 & 24 & 23 & 26 \\
\hline Colchr ${ }^{\mathrm{b}}$ & $\mathrm{n} / \mathrm{a}$ & & & & & & \\
\hline Dudley & 100.0 & 52 & 25.7 & 3.3 & 26 & 23 & 28 \\
\hline Exeter & 98.6 & 70 & 24.2 & 2.9 & 24 & 22 & 26 \\
\hline Glouc & 100.0 & 28 & 24.4 & 3.3 & 25 & 23 & 27 \\
\hline Hull & 98.5 & 65 & 24.9 & 3.5 & 25 & 22 & 27 \\
\hline Ipswi & 100.0 & 27 & 25.5 & 3.0 & 25 & 24 & 28 \\
\hline Kent & 100.0 & 54 & 24.5 & 2.8 & 25 & 23 & 26 \\
\hline L Barts & 98.4 & 179 & 24.1 & 3.2 & 25 & 22 & 26 \\
\hline L Guys & 100.0 & 29 & 23.6 & 2.4 & 24 & 22 & 25 \\
\hline L Kings & 98.8 & 79 & 26.6 & 2.5 & 26 & 25 & 28 \\
\hline L Rfree & 81.3 & 109 & 24.5 & 3.0 & 25 & 22 & 27 \\
\hline L St.G & 97.8 & 44 & 24.4 & 2.2 & 24 & 23 & 26 \\
\hline Norwch & 96.4 & 27 & 22.4 & 2.7 & 23 & 20 & 25 \\
\hline Nottm & 48.4 & 31 & & & & & \\
\hline Oxford & 88.5 & 69 & 23.5 & 3.9 & 24 & 21 & 26 \\
\hline Plymth & 96.4 & 27 & 24.2 & 3.3 & 24 & 22 & 27 \\
\hline Ports & 93.3 & 56 & 25.6 & 3.1 & 26 & 23 & 28 \\
\hline Prestn & 100.0 & 49 & 26.6 & 3.1 & 27 & 24 & 29 \\
\hline Redng & 100.0 & 59 & 27.0 & 2.6 & 27 & 25 & 29 \\
\hline Salford & 14.6 & 12 & & & & & \\
\hline Sheff & 100.0 & 53 & 22.8 & 3.1 & 23 & 21 & 25 \\
\hline Shrew & 100.0 & 27 & 26.0 & 3.3 & 26 & 24 & 29 \\
\hline Stevng & 92.3 & 12 & 24.3 & 3.6 & 23 & 22 & 27 \\
\hline Sthend & 100.0 & 15 & 26.2 & 1.7 & 26 & 25 & 28 \\
\hline Stoke & 98.6 & 69 & 27.5 & 2.7 & 28 & 26 & 29 \\
\hline Sund & 92.9 & 13 & 23.4 & 3.2 & 23 & 21 & 26 \\
\hline Truro & 89.5 & 17 & 26.8 & 2.7 & 27 & 26 & 28 \\
\hline Wirral & 100.0 & 17 & 26.8 & 2.7 & 27 & 25 & 28 \\
\hline Wolve & 98.5 & 67 & 23.0 & 2.8 & 23 & 21 & 25 \\
\hline York & 95.5 & 21 & 25.8 & 3.5 & 26 & 25 & 28 \\
\hline
\end{tabular}


Table 8.11. Continued

\begin{tabular}{|c|c|c|c|c|c|c|c|}
\hline Centre & $\begin{array}{c}\% \\
\text { completeness }\end{array}$ & $\begin{array}{c}\text { Patients with data } \\
\qquad N\end{array}$ & Mean & $\mathrm{SD}$ & Median & $\begin{array}{l}\text { Lower } \\
\text { quartile }\end{array}$ & $\begin{array}{l}\text { Upper } \\
\text { quartile }\end{array}$ \\
\hline \multicolumn{8}{|l|}{ N Ireland } \\
\hline Belfast & 100.0 & 19 & 25.1 & 3.6 & 25 & 24 & 28 \\
\hline Newry & 100.0 & 18 & 26.3 & 3.7 & 27 & 23 & 29 \\
\hline Ulster & 100.0 & 6 & & & & & \\
\hline \multicolumn{8}{|l|}{ Wales } \\
\hline Bangor & 100.0 & 13 & 26.0 & 3.0 & 27 & 23 & 28 \\
\hline Cardff & 94.4 & 68 & 25.7 & 2.8 & 26 & 25 & 27 \\
\hline Clwyd & 92.3 & 12 & 23.5 & 2.5 & 24 & 22 & 25 \\
\hline Swanse & 98.2 & 54 & 27.0 & 2.7 & 27 & 25 & 30 \\
\hline Wrexm & 100.0 & 33 & 26.1 & 3.0 & 26 & 25 & 28 \\
\hline
\end{tabular}

Blank cells: centres excluded from analysis due to low patient numbers or poor data completeness

${ }^{a}$ Cambridge renal centre was unable to submit bicarbonate data for 2015

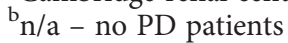

Table 8.12. Percentage of peritoneal dialysis patients within, below and above the range for bicarbonate (22-30 mmol/L) by centre in 2015

\begin{tabular}{|c|c|c|c|c|c|c|c|c|c|}
\hline Centre & $N$ & $\begin{array}{c}\% \text { bicarb } \\
22-30 \mathrm{mmol} / \mathrm{L}\end{array}$ & $\begin{array}{l}\text { Lower } \\
95 \% \text { CI }\end{array}$ & $\begin{array}{l}\text { Upper } \\
95 \% \text { CI }\end{array}$ & $\begin{array}{c}\% \text { bicarb } \\
<22 \mathrm{mmol} / \mathrm{L}\end{array}$ & $\begin{array}{c}\% \text { bicarb } \\
>30 \mathrm{mmol} / \mathrm{L}\end{array}$ & $\begin{array}{c}\text { Change in } \% \\
\text { within range } \\
\text { from } 2014\end{array}$ & $\begin{array}{c}95 \% \\
\text { LCL } \\
\text { change }\end{array}$ & $\begin{array}{c}95 \% \\
\text { UCL } \\
\text { change }\end{array}$ \\
\hline B Heart & 40 & 55.0 & 39.6 & 69.5 & 45.0 & 0.0 & -22.4 & -43.7 & -1.1 \\
\hline B QEH & 112 & 81.3 & 73.0 & 87.4 & 18.8 & 0.0 & -6.3 & -15.9 & 3.4 \\
\hline Basldn & 27 & 85.2 & 66.5 & 94.3 & 11.1 & 3.7 & 3.4 & -17.6 & 24.3 \\
\hline Brightn & 60 & 81.7 & 69.9 & 89.6 & 15.0 & 3.3 & -1.7 & -15.6 & 12.3 \\
\hline Bristol & 47 & 44.7 & 31.3 & 58.9 & 55.3 & 0.0 & -20.8 & -39.7 & -1.8 \\
\hline Carlis & 30 & 80.0 & 62.1 & 90.7 & 20.0 & 0.0 & -10.9 & -29.6 & 7.8 \\
\hline Chelms & 22 & 81.8 & 60.4 & 93.0 & 13.6 & 4.6 & -7.1 & -28.8 & 14.6 \\
\hline Covnt & 72 & 80.6 & 69.8 & 88.1 & 15.3 & 4.2 & -10.4 & -21.5 & 0.8 \\
\hline Exeter & 70 & 78.6 & 67.4 & 86.7 & 20.0 & 1.4 & -9.4 & -21.3 & 2.5 \\
\hline Glouc & 28 & 82.1 & 63.6 & 92.4 & 17.9 & 0.0 & -12.5 & -28.4 & 3.5 \\
\hline
\end{tabular}


Table 8.12. Continued

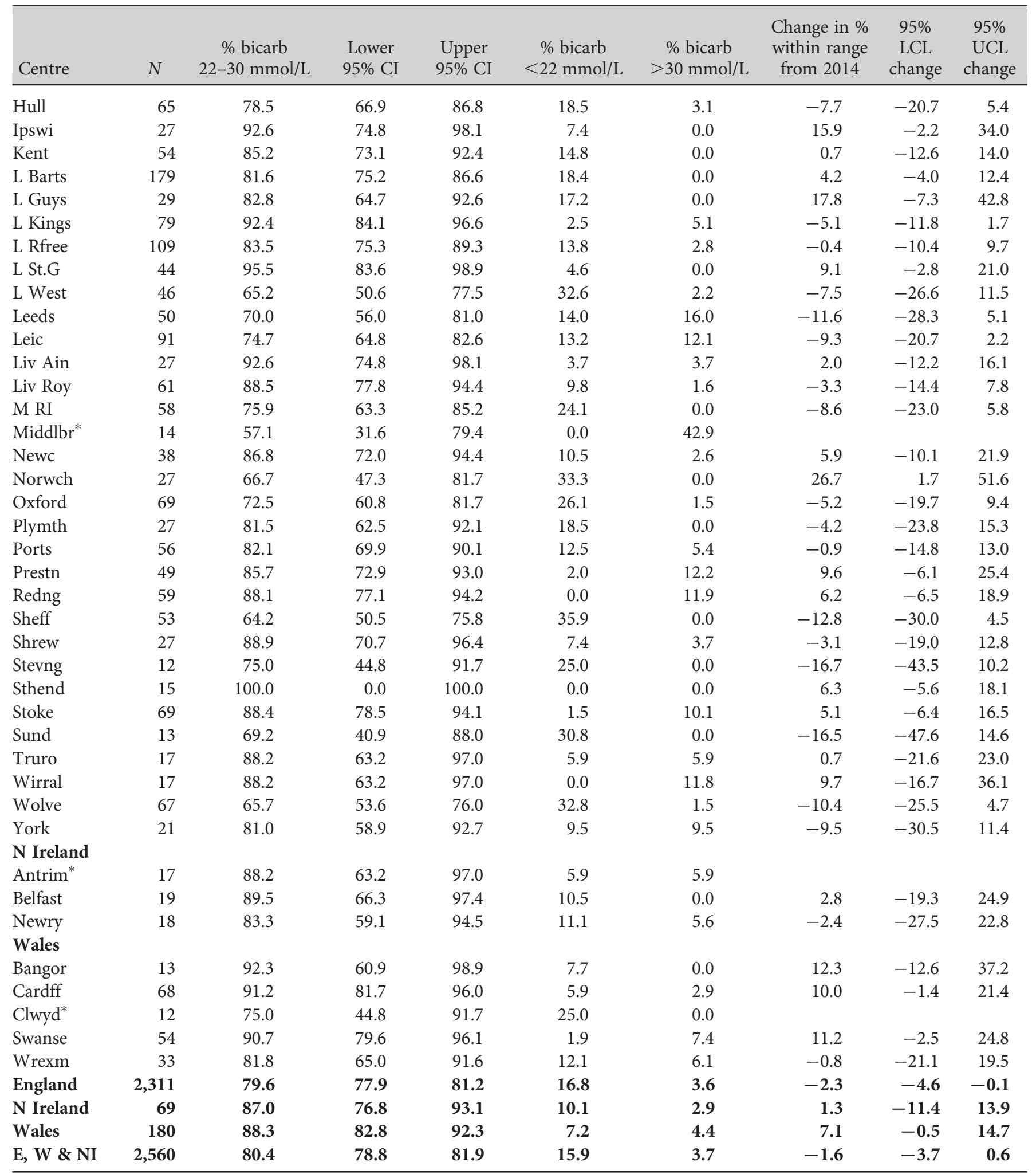

Centres missing from the table were excluded from analysis due to low patient numbers or poor data completeness

*Bank cells indicate no data for 2014 


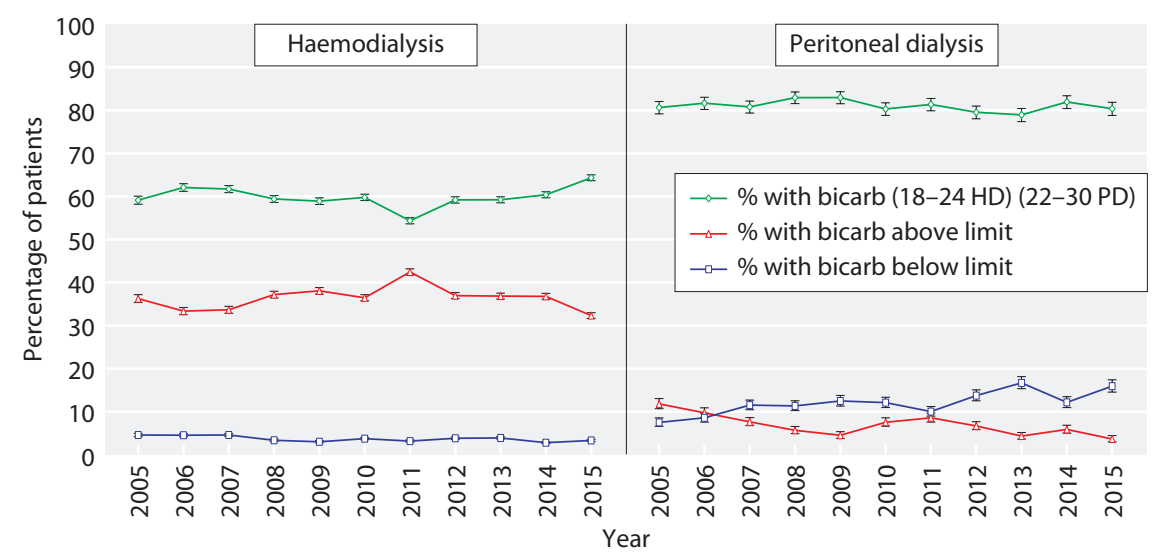

Fig. 8.14. Longitudinal change in percentage of patients within the range for bicarbonate by dialysis modality $2005-2015$ differences in dialysis, residual renal function and oral bicarbonate prescriptions may all contribute to the variation observed.

Serial trends in serum bicarbonate measures between 2005 and 2015 by dialysis modality are presented in figure 8.14. Achievement of bicarbonate audit measures has not changed over the past decade for either modality. There has been a consistent difference between the modalities in the percentage with raised bicarbonate measures.

\section{Discussion}

A number of studies have demonstrated reduced dialysis patient survival with disordered calcium and phosphate levels $[9,10]$ as well as with inadequate simultaneous control of three MBD parameters [11-13]. This chapter presents the results of MBD management for established renal failure patients in the UK and demonstrates the overall ongoing improvement in achieving measures. However, the inter- and intra-centre variation in the control of MBD parameters remains a challenge. Some of these apparent differences may be as a result of confounding factors, rather than true differences in the quality of care. Analyses including adjustment for patient level factors will be undertaken in future years when the enhanced UKRR dataset is available from renal centres, such as comorbidity, phosphate binder, calcium mimetic and vitamin D analogue use and the dialysis dose and dialysate concentrations prescribed. In addition to adjusting for patient level factors (to account for case-mix) there are also centre level factors. The UKRR 7th Annual Report chapter 8 [14] discussed the problems related to variations in calcium and PTH measurements. It is an aspiration for future work also to integrate these into the analyses, such as assays used for the biochemical parameters and the local reference ranges. Overall data completeness was good for the biochemical variables presented in this chapter with some exceptions and data completeness has improved over the years. However, the UKRR will need to attain good data completeness for a host of other patient and centre level variables in order to undertake the adjusted analyses described.

Serum bicarbonate levels have not changed significantly compared with recent years, but a persistent fraction of HD patients still have raised bicarbonate levels. The UKRR has previously conducted a limited survey [15] into the possible underlying causes of serum bicarbonate variation. The study examined measures of sample processing and of dialysis treatment. It did not adjust for case-mix and was unable to detect any significant differences between centres. Studies have identified an increased risk of death stratified by a reduced predialysis serum bicarbonate level $(<17 \mathrm{mmol} / \mathrm{L})$ or with raised levels $(>27 \mathrm{mmol} / \mathrm{L})$ [16-17], as well as with raised dialysate bicarbonate concentrates [11]. Future analysis of management of acidosis will have to reexplore the factors associated with an increased trend in developing alkalosis in HD patients.

Conflicts of interest: the authors declare no conflict of interest

\section{References}

1 Renal Association. Clinical Practice Guidelines. 6th Edition. http://www. renal.org/guidelines/currentguidelines

2 Kidney Disease: Improving Global Outcomes (KDIGO) CKD-MBD Work Group. KDIGO clinical practice guideline for the diagnosis, evaluation, prevention, and treatment of chronic kidney disease-mineral and bone disorder (CKD-MBD). Kidney International 2009;76(Suppl 113): S1-S130 
3 Steddon S, Sharples E. Renal Association Clinical Practice Guideline. CKD-Mineral and Bone Disorders, 2015. http://www.renal.org/docs/ default-source/default-document-library/ckd-mineral-and-bonedisorders-(ckd-mbd)204ca231181561659443ff000014d4d8.pdf?sfvrsn =0

4 Ansell D, Tomson CRV, Chapter 15 UK Renal Registry Annual Report: U.K. Renal Registry, UKRR database, validation and methodology. Nephron Clin Pract. 2009;111(Suppl 1):c277-85

5 Morton AR, Garland JS, Holden RM: Is the calcium correct? Measuring serum calcium in dialysis patients. Semin Dial. 2010;23(3):283-289

6 Spiegelhalter DJ: Funnel plots for comparing institutional performance. Statistics in Medicine 2005;24:1185-1202

7 Mactier R, Hoenich N, Breen C. Renal Association Clinical Practice Guideline Haemodialysis, 2009. http://www.renal.org/guidelines/oldguidelines. Woodrow G, Davies S. Renal Association Clinical Practice Guideline Peritoneal Dialysis, 2010. http://www.renal.org/guidelines/ old-guidelines

8 Noordzij M, Korevaar JC, Bos WJ, Boeschoten EW, Dekker FW, Bossuyt PM, Krediet RT: Mineral metabolism and cardiovascular morbidity and mortality risk: peritoneal dialysis patients compared with haemodialysis patients. Nephrol Dial Transplant 2006;21:2513-2520.

9 Kalantar-Zadeh K, Kuwae N, Regidor DL, Kovesdy CP, Kilpatrick RD, Shinaberger CS, McAllister CJ, Budoff MJ, Salusky IB, Kopple JD: Survival predictability of time-varying indicators of bone disease in maintenance hemodialysis patients. Kidney Int 2006;70:771-780.

10 Tentori F, Blayney MJ, Albert JM, Gillespie BW, Kerr PG, Bommer J, Young EW, Akizawa T, Akiba T, Pisoni RL, Robinson BM, Port FK: Mortality risk for dialysis patients with different levels of serum calcium, phosphorus, and PTH: the Dialysis Outcomes and Practice Patterns Study (DOPPS). Am J Kidney Dis 2008;52:519-530.
11 Block GA, Kilpatrick RD, Lowe KA, Wang W, Danese MD: CKDmineral and bone disorder and risk of death and cardiovascular hospitalization in patients on hemodialysis. Clin J Am Soc Nephrol 2013;8:2132-2140.

12 Danese MD, Belozeroff V, Smirnakis K, Rothman KJ: Consistent control of mineral and bone disorder in incident hemodialysis patients. Clin J Am Soc Nephrol 2008;3:1423-1429.

13 Shaw C, Nicholas J, Pitcher D, Dawnay A: UK Renal Registry 17th Annual Report: Chapter 8 Biochemical Variables amongst UK Adult Dialysis Patients in 2013: National and Centre-specific Analyses. Nephron 2015;129(suppl 1):169-208.

14 Ansell D, Feest TG: Renal registry 7th annual report. Chapter 6: Adequacy of haemodialysis and serum bicarbonate, Renal registry 7 th annual report. Chapter 6: Adequacy of haemodialysis and serum bicarbonate. 2004, pp 59-86.

15 Wu DY, Shinaberger CS, Regidor DL, McAllister CJ, Kopple JD, Kalantar-Zadeh K: Association between serum bicarbonate and death in hemodialysis patients: Is it better to be acidotic or alkalotic? Clinical Journal of the American Society of Nephrology 2006;1:70-78.

16 Lowrie EG, Lew NL: Death risk in hemodialysis patients: the predictive value of commonly measured variables and an evaluation of death rate differences between facilities. American Journal of Kidney Diseases 1990;15:458-482.

17 Bommer J, Locatelli F, Satayathum S, Keen ML, Goodkin DA, Saito A, Akiba T, Port FK, Young EW: Association of predialysis serum bicarbonate levels with risk of mortality and hospitalization in the Dialysis Outcomes and Practice Patterns Study (DOPPS). Am J Kidney Dis 2004;44:661-671. 


\section{Appendix 1 Attainment of individual standard for adjusted calcium, phosphate and PTH}

This appendix includes analysis of the individual mineral bone measures that are included in the composite audit measure, namely adjusted calcium, phosphate and PTH within the recommended target ranges.

\section{Adjusted calcium}

In 2015, the following Renal Association clinical practice guideline regarding calcium management was applicable:

Guideline 2.2 CKD-MBD: Serum calcium in dialysis patients (stage 5D)

'We suggest that serum calcium, adjusted for albumin concentration, should be maintained within the normal reference range for the laboratory used, measured before a "short-gap" dialysis session in haemodialysis patients. Ideally, adjusted serum calcium should be maintained between 2.2 and $2.5 \mathrm{mmol} / \mathrm{L}$, with avoidance of hypercalcaemic episodes (2D)' [3].

In 2015, data from 22,175 HD and 2,998 PD patients across the UK were available for serum adjusted calcium analysis. The data were $98.4 \%$ complete for HD patients and $98.7 \%$ complete for PD patients overall, although there was between centre variation (tables 8.13, 8.15). From 2004 to 2015 across UK centres, data completeness for serum adjusted calcium increased from $57.2 \%$ to $98.0 \%$ in $\mathrm{HD}$ patients and from $56.8 \%$ to $98.7 \%$ in PD patients.

London West and Belfast did not return locally adjusted calcium results for any patients, whilst Sunderland and Wirral returned adjusted calcium results for only a proportion of their patients. Hence these data are shown after adjustment using a generic formula that may not be applicable to the calcium and albumin methods used locally and may have over- or underestimated the adjusted calcium. These centres are served

Table 8.13. Summary statistics for adjusted calcium in haemodialysis patients in 2015

\begin{tabular}{|c|c|c|c|c|c|c|c|}
\hline Centre & $\begin{array}{c}\% \\
\text { completeness }\end{array}$ & $\begin{array}{c}\text { Patients with data } \\
\qquad N\end{array}$ & Mean & $\mathrm{SD}$ & Median & $\begin{array}{l}\text { Lower } \\
\text { quartile }\end{array}$ & $\begin{array}{l}\text { Upper } \\
\text { quartile }\end{array}$ \\
\hline \multicolumn{8}{|l|}{ England } \\
\hline B Heart & 99.8 & 396 & 2.4 & 0.2 & 2.4 & 2.3 & 2.5 \\
\hline B QEH & 98.3 & 917 & 2.3 & 0.2 & 2.3 & 2.2 & 2.4 \\
\hline Basldn & 99.4 & 152 & 2.4 & 0.2 & 2.4 & 2.3 & 2.5 \\
\hline Bradfd & 100.0 & 217 & 2.4 & 0.1 & 2.3 & 2.3 & 2.4 \\
\hline Brightn & 100.0 & 402 & 2.3 & 0.2 & 2.3 & 2.2 & 2.4 \\
\hline Bristol & 100.0 & 489 & 2.4 & 0.1 & 2.4 & 2.3 & 2.5 \\
\hline \multicolumn{8}{|l|}{ Camb* } \\
\hline Carlis & 100.0 & 74 & 2.3 & 0.2 & 2.3 & 2.2 & 2.4 \\
\hline Carsh & 99.7 & 759 & 2.3 & 0.2 & 2.3 & 2.2 & 2.4 \\
\hline Chelms & 99.3 & 138 & 2.3 & 0.2 & 2.3 & 2.2 & 2.4 \\
\hline Colchr & 94.6 & 105 & 2.4 & 0.1 & 2.4 & 2.3 & 2.4 \\
\hline Covnt & 100.0 & 332 & 2.3 & 0.2 & 2.3 & 2.2 & 2.4 \\
\hline Derby & 99.6 & 221 & 2.5 & 0.2 & 2.5 & 2.4 & 2.6 \\
\hline Donc & 100.0 & 163 & 2.4 & 0.1 & 2.4 & 2.3 & 2.5 \\
\hline Dorset & 100.0 & 270 & 2.3 & 0.1 & 2.3 & 2.2 & 2.4 \\
\hline Dudley & 100.0 & 155 & 2.3 & 0.2 & 2.3 & 2.2 & 2.4 \\
\hline Exeter & 100.0 & 403 & 2.4 & 0.1 & 2.3 & 2.3 & 2.4 \\
\hline Glouc & 100.0 & 216 & 2.4 & 0.1 & 2.4 & 2.3 & 2.4 \\
\hline Hull & 99.7 & 326 & 2.4 & 0.2 & 2.4 & 2.3 & 2.5 \\
\hline Ipswi & 100.0 & 129 & 2.4 & 0.2 & 2.4 & 2.3 & 2.5 \\
\hline Kent & 99.5 & 395 & 2.4 & 0.2 & 2.4 & 2.3 & 2.5 \\
\hline L Barts & 100.0 & 928 & 2.3 & 0.2 & 2.3 & 2.2 & 2.4 \\
\hline L Guys & 100.0 & 629 & 2.3 & 0.2 & 2.4 & 2.2 & 2.4 \\
\hline L Kings & 100.0 & 522 & 2.3 & 0.2 & 2.3 & 2.2 & 2.4 \\
\hline L Rfree & 100.0 & 665 & 2.3 & 0.2 & 2.3 & 2.2 & 2.4 \\
\hline
\end{tabular}


Table 8.13. Continued

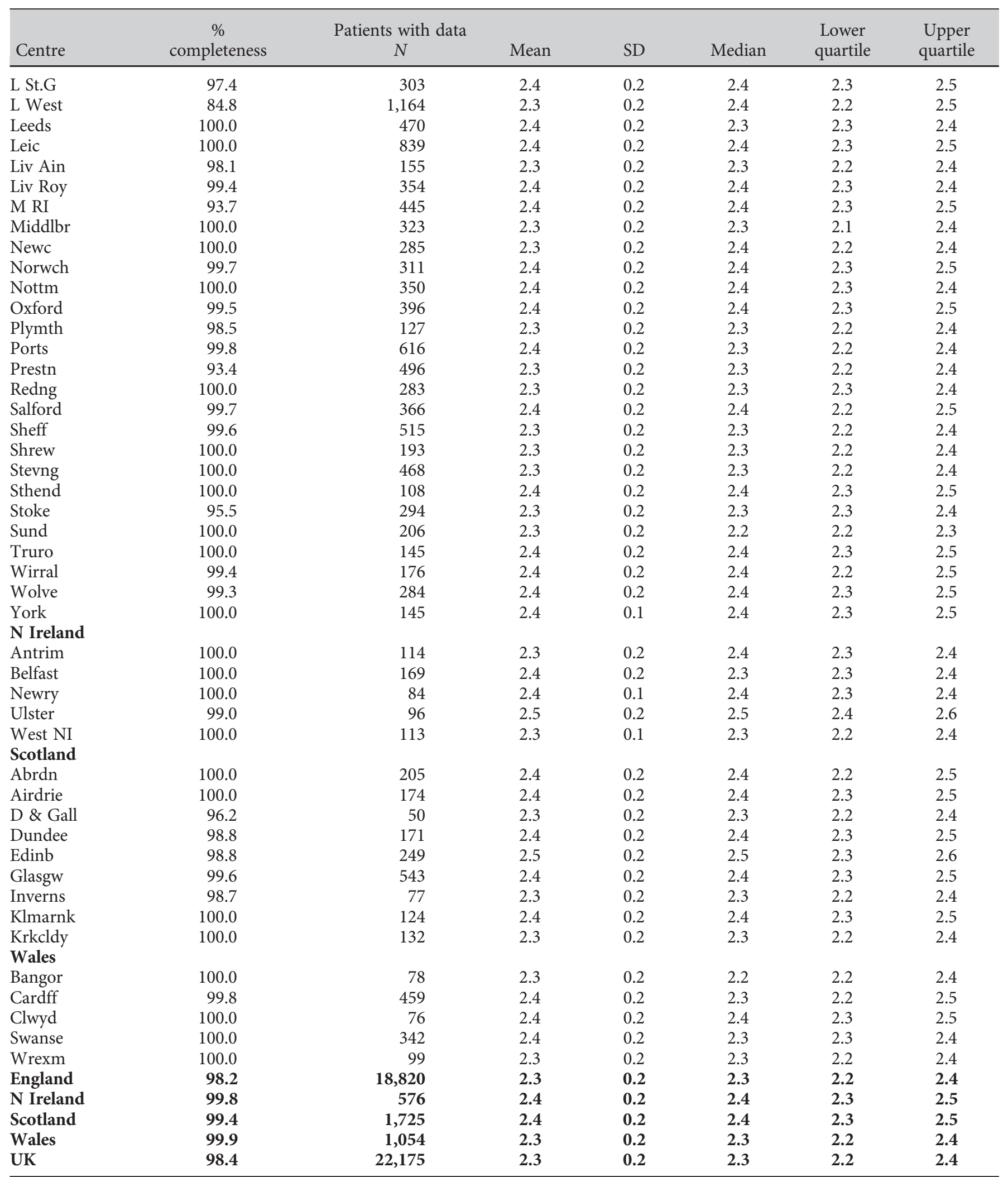

* Cambridge renal centre was unable to submit adjusted calcium data for 2015

Management of biochemical variables

Nephron 2017;137(suppl1):189-234 
Table 8.14. Percentage of haemodialysis patients within, below and above the range for adjusted calcium (2.2-2.5 mmol/L) in 2015

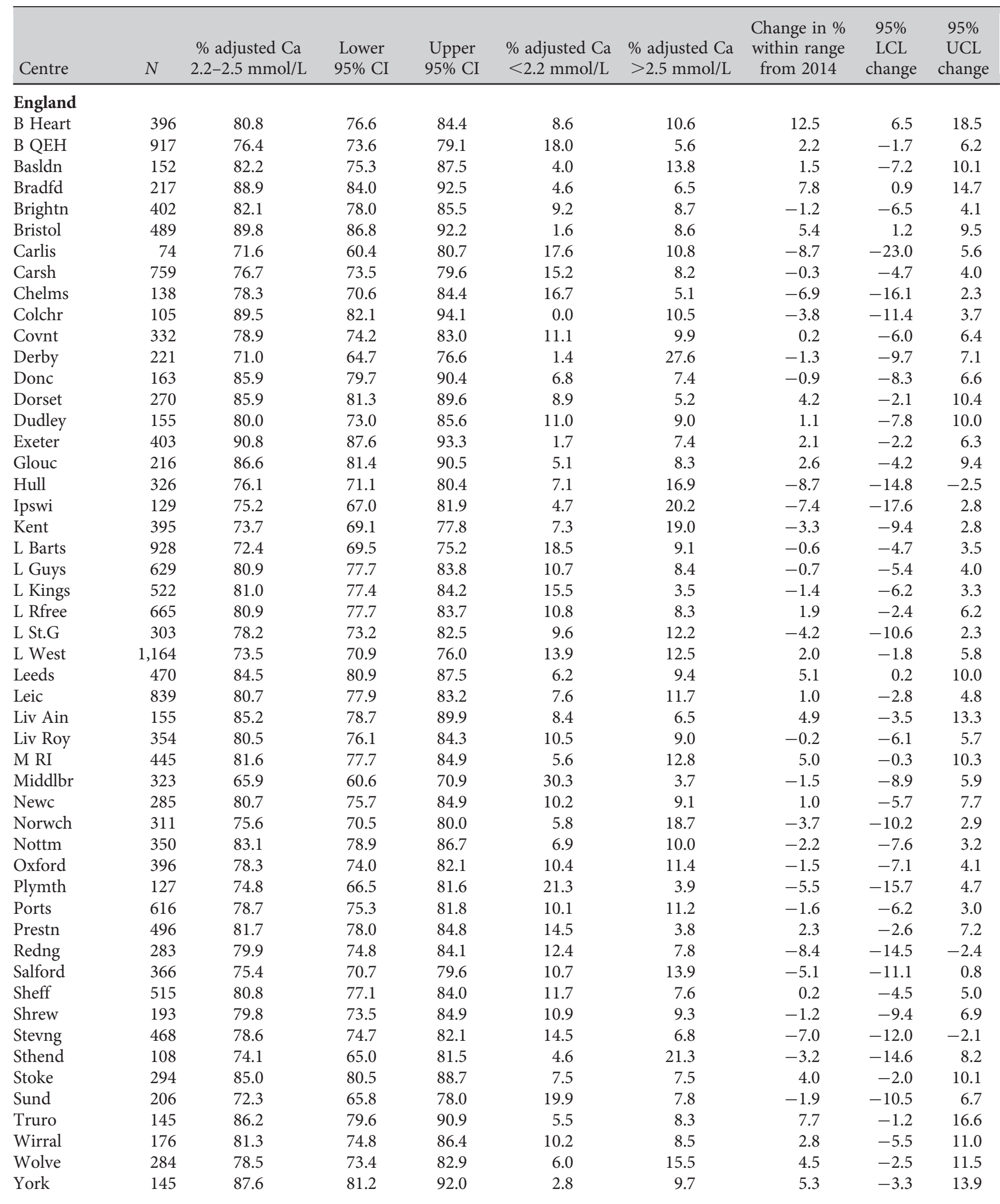


Table 8.14. Continued

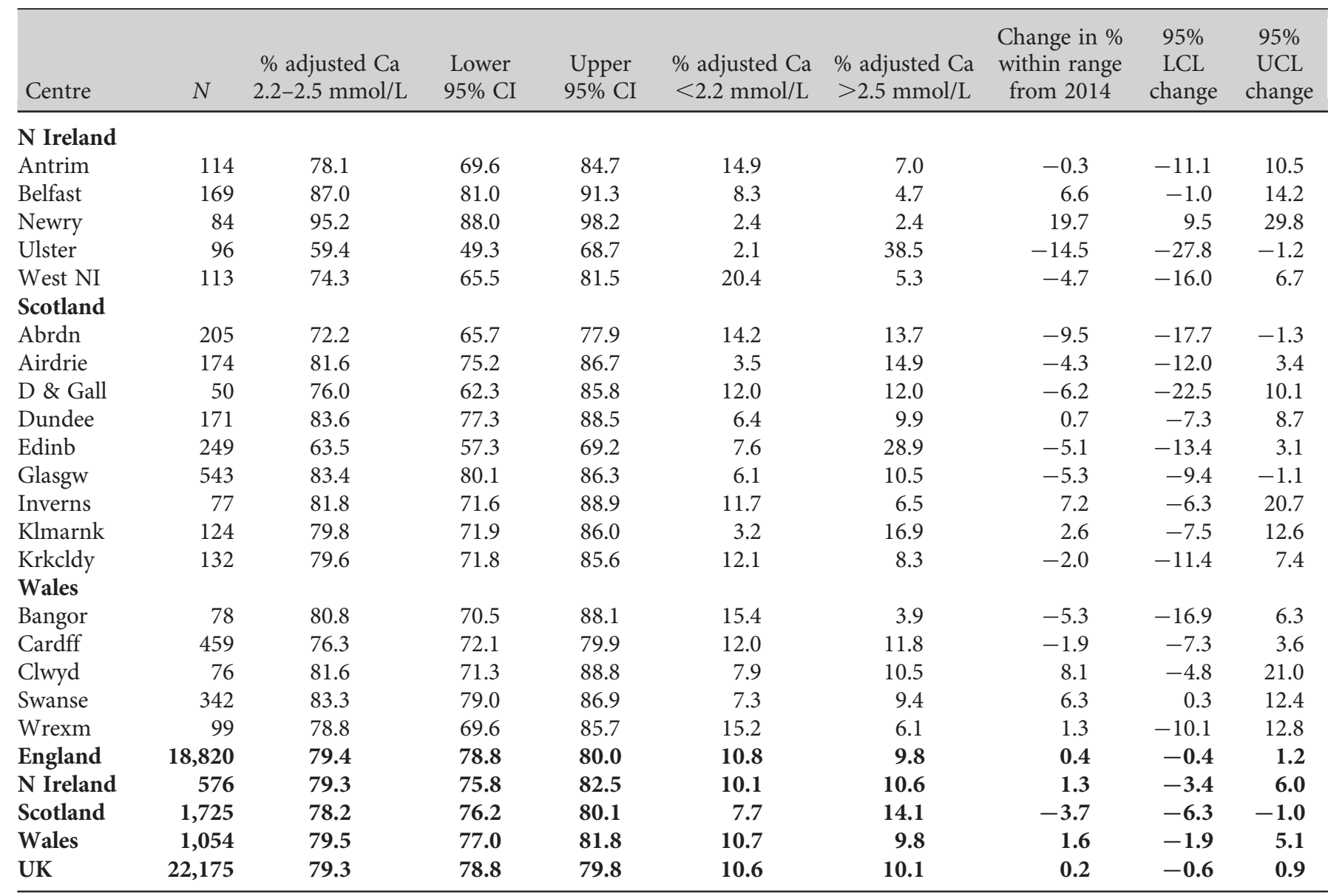

Centres missing from the table were excluded from analysis due to low patient numbers or poor data completeness

by laboratories that report adjusted calcium results and therefore it should be possible to report the adjusted values to the UKRR.

Of HD patients, $79.3 \%$ (95\% CI 78.8-79.8\%) and of PD patients 77.8\% (95\% CI 76.3-79.2\%) had an adjusted calcium between 2.2-2.5 mmol/L (tables 8.14, 8.16, figures $8.15,8.17$ ).

The proportion of hypocalcaemic patients in the UK was $10.6 \%$ for HD and $7.4 \%$ for PD (tables $8.14,8.16$ ). The proportion of hypercalcaemic patients in the UK was $10.1 \%$ for HD and $14.8 \%$ for PD (tables $8.14,8.16$ ).

Figure 8.16 presents the funnel plot of HD patients attaining adjusted calcium levels between 2.2 and $2.5 \mathrm{mmol} / \mathrm{L}$ in 2015. Five centre's results fell below the lower 99.9\% confidence interval: Ulster, Edinburgh, Middlesbrough, London St Bartholomew's and London West. However, the London West data may be misleading since the centre failed to return locally adjusted calcium results. The percentage of $\mathrm{HD}$ patients with serum calcium within the reference range was significantly higher than the average (above the 99.9\% confidence limit) in Newry, Colchester, Bradford, Exeter and Bristol.

Figure 8.18 presents the funnel plot of PD patients attaining the adjusted calcium levels between 2.2 and $2.5 \mathrm{mmol} / \mathrm{L}$ in 2015 . Once corrected for centre size, no centre was significantly lower than the national average. There were three centres achieving a significantly higher percentage compared with the UK average: Truro, Leeds and Oxford.

Longitudinal changes in the control measures of serum adjusted calcium show improvements in the attained national standards. Hypocalcaemia in HD patients has declined since 2010, with no significant changes being observed in PD patients. In the same time period there has been a modest fall in hypercalcaemia in both modalities (figure 8.19). 


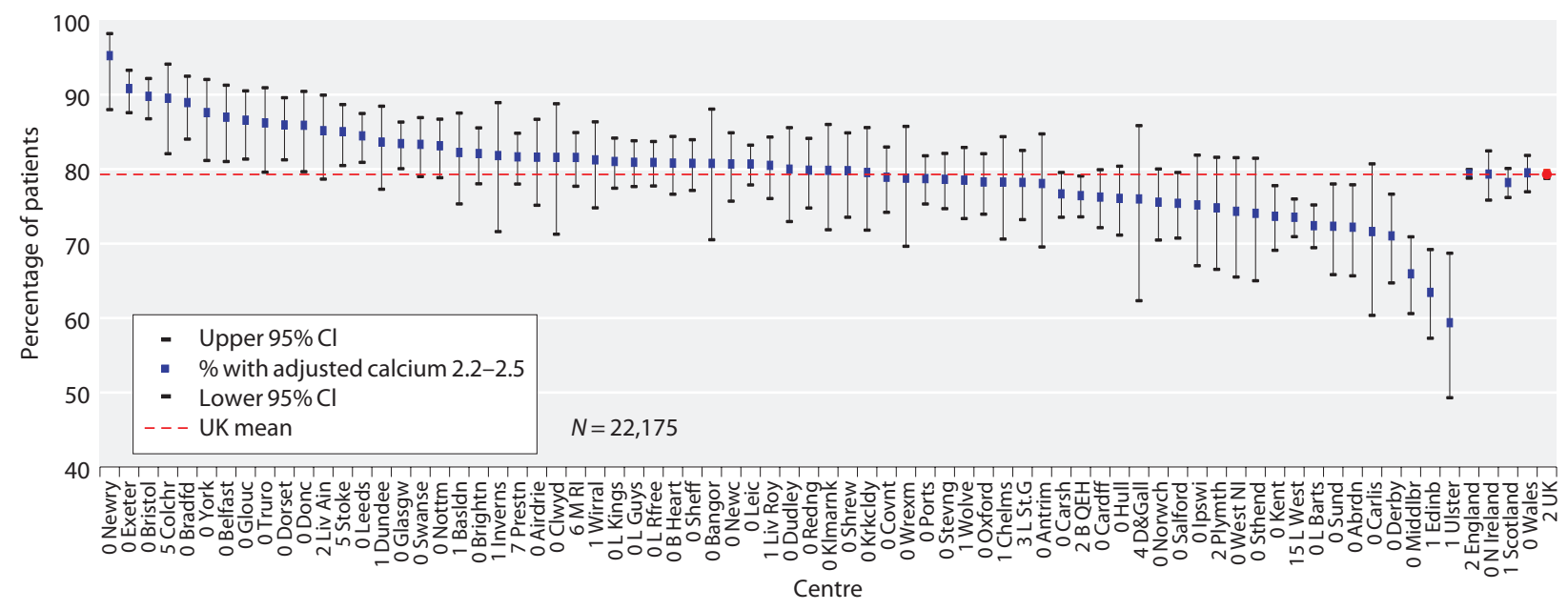

Fig. 8.15. Percentage of haemodialysis patients with adjusted calcium within range $(2.2-2.5 \mathrm{mmol} / \mathrm{L})$ by centre in 2015

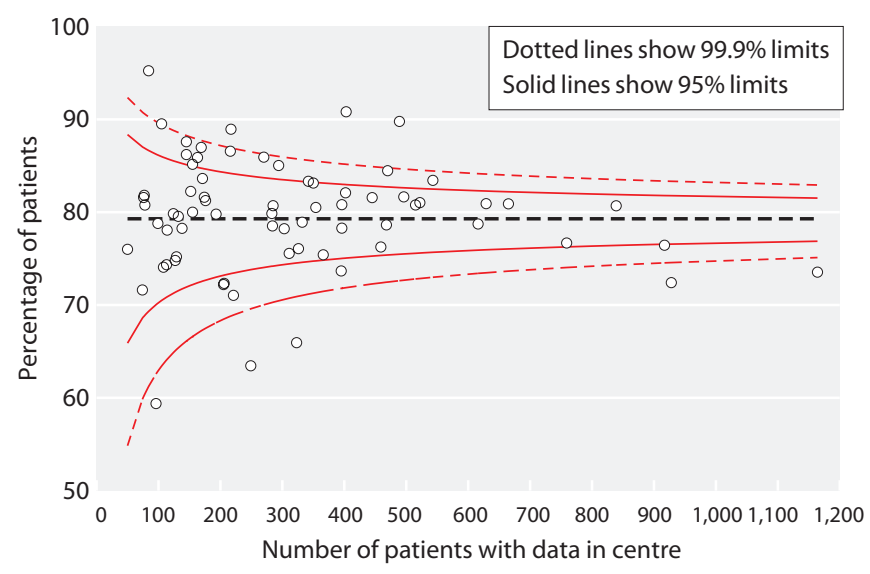

Fig. 8.16. Funnel plot of percentage of haemodialysis patients with adjusted calcium within range $(2.2-2.5 \mathrm{mmol} / \mathrm{L})$ by centre in 2015

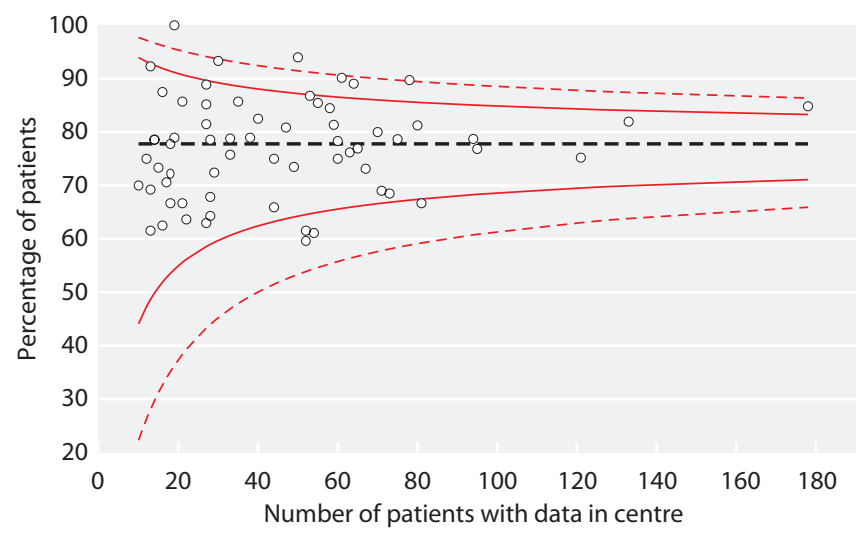

Fig. 8.18. Funnel plot of percentage of peritoneal dialysis patients with adjusted calcium within range $(2.2-2.5 \mathrm{mmol} / \mathrm{L})$ by centre in 2015

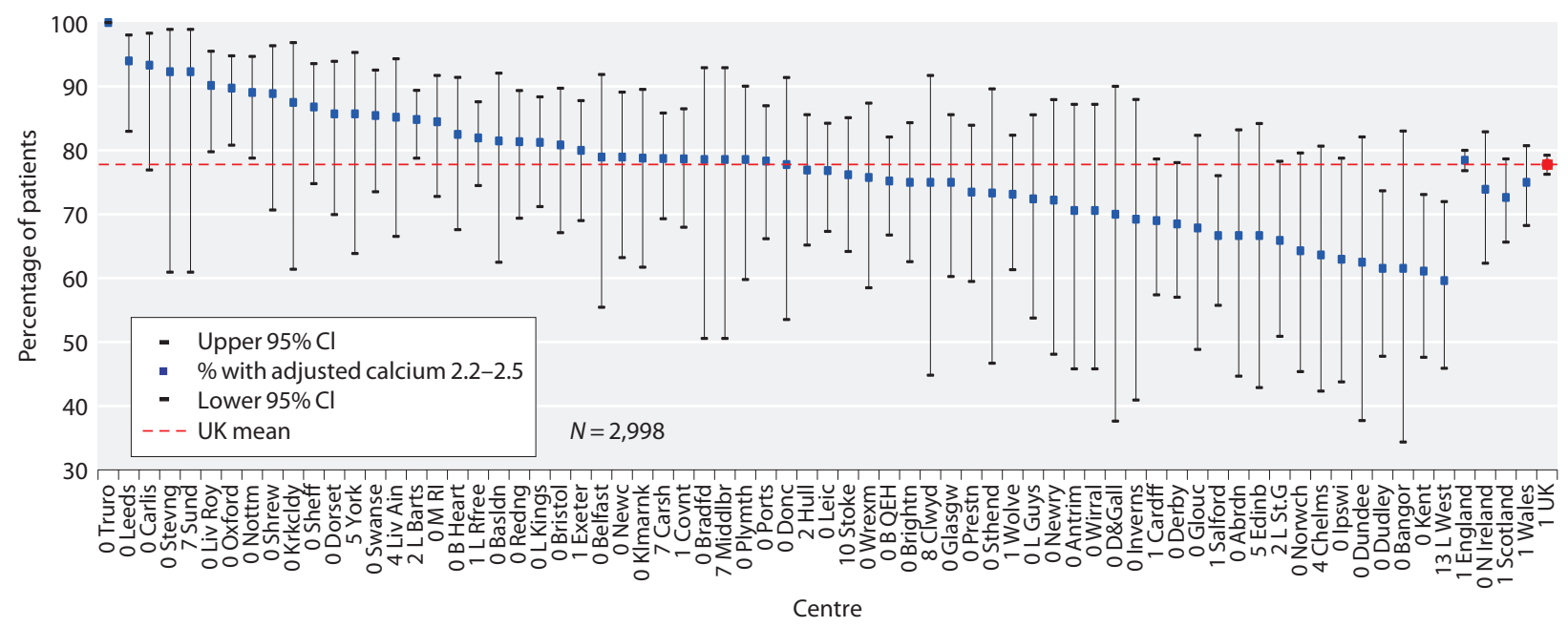

Fig. 8.17. Percentage of peritoneal dialysis patients with adjusted calcium within range $(2.2-2.5 \mathrm{mmol} / \mathrm{L})$ by centre in 2015 
Table 8.15. Summary statistics for adjusted calcium in peritoneal dialysis patients in 2015

\begin{tabular}{|c|c|c|c|c|c|c|c|}
\hline Centre & $\begin{array}{c}\% \\
\text { completeness }\end{array}$ & $\begin{array}{c}\text { Patients with data } \\
\qquad N\end{array}$ & Mean & $\mathrm{SD}$ & Median & $\begin{array}{c}\text { Lower } \\
\text { quartile }\end{array}$ & $\begin{array}{l}\text { Upper } \\
\text { quartile }\end{array}$ \\
\hline \multicolumn{8}{|l|}{ England } \\
\hline B QEH & 100.0 & 121 & 2.3 & 0.2 & 2.3 & 2.2 & 2.5 \\
\hline Basldn & 100.0 & 27 & 2.4 & 0.2 & 2.4 & 2.3 & 2.5 \\
\hline Bradfd & 100.0 & 14 & 2.4 & 0.2 & 2.4 & 2.3 & 2.5 \\
\hline \multicolumn{8}{|l|}{$\mathrm{Camb}^{\mathrm{a}}$} \\
\hline Carlis & 100.0 & 30 & 2.3 & 0.1 & 2.3 & 2.2 & 2.3 \\
\hline Carsh & 93.1 & 94 & 2.3 & 0.2 & 2.3 & 2.2 & 2.4 \\
\hline Chelms & 95.7 & 22 & 2.3 & 0.2 & 2.3 & 2.2 & 2.4 \\
\hline \multicolumn{8}{|l|}{ Colchr ${ }^{\mathrm{b}}$} \\
\hline Dudley & 100.0 & 52 & 2.5 & 0.2 & 2.5 & 2.4 & 2.6 \\
\hline Exeter & 98.6 & 70 & 2.4 & 0.2 & 2.4 & 2.3 & 2.5 \\
\hline Glouc & 100.0 & 28 & 2.4 & 0.2 & 2.4 & 2.3 & 2.5 \\
\hline Hull & 98.5 & 65 & 2.4 & 0.1 & 2.4 & 2.3 & 2.5 \\
\hline Ipswi & 100.0 & 27 & 2.3 & 0.2 & 2.3 & 2.2 & 2.4 \\
\hline Kent & 100.0 & 54 & 2.5 & 0.1 & 2.5 & 2.4 & 2.6 \\
\hline L Barts & 97.8 & 178 & 2.3 & 0.2 & 2.3 & 2.2 & 2.4 \\
\hline L Guys & 100.0 & 29 & 2.4 & 0.1 & 2.4 & 2.3 & 2.5 \\
\hline L Kings & 100.0 & 80 & 2.3 & 0.2 & 2.3 & 2.2 & 2.4 \\
\hline L Rfree & 99.3 & 133 & 2.4 & 0.2 & 2.4 & 2.3 & 2.5 \\
\hline L St.G & 97.8 & 44 & 2.5 & 0.2 & 2.5 & 2.4 & 2.6 \\
\hline Norwch & 100.0 & 28 & 2.5 & 0.1 & 2.5 & 2.4 & 2.6 \\
\hline Nottm & 100.0 & 64 & 2.4 & 0.2 & 2.4 & 2.3 & 2.5 \\
\hline Oxford & 100.0 & 78 & 2.4 & 0.1 & 2.4 & 2.3 & 2.5 \\
\hline Plymth & 100.0 & 28 & 2.3 & 0.2 & 2.3 & 2.2 & 2.4 \\
\hline Ports & 100.0 & 60 & 2.4 & 0.2 & 2.4 & 2.3 & 2.5 \\
\hline Prestn & 100.0 & 49 & 2.3 & 0.2 & 2.3 & 2.2 & 2.4 \\
\hline Redng & 100.0 & 59 & 2.4 & 0.2 & 2.4 & 2.3 & 2.5 \\
\hline Salford & 98.8 & 81 & 2.4 & 0.2 & 2.4 & 2.3 & 2.6 \\
\hline Sheff & 100.0 & 53 & 2.3 & 0.1 & 2.3 & 2.2 & 2.4 \\
\hline Shrew & 100.0 & 27 & 2.4 & 0.1 & 2.3 & 2.2 & 2.4 \\
\hline Stevng & 100.0 & 13 & 2.3 & 0.1 & 2.3 & 2.2 & 2.4 \\
\hline Sthend & 100.0 & 15 & 2.5 & 0.1 & 2.4 & 2.4 & 2.6 \\
\hline Stoke & 90.0 & 63 & 2.4 & 0.2 & 2.4 & 2.3 & 2.5 \\
\hline Sund & 92.9 & 13 & 2.4 & 0.1 & 2.4 & 2.3 & 2.4 \\
\hline Truro & 100.0 & 19 & 2.4 & 0.1 & 2.4 & 2.3 & 2.4 \\
\hline Wirral & 100.0 & 17 & 2.3 & 0.2 & 2.3 & 2.2 & 2.4 \\
\hline Wolve & 98.5 & 67 & 2.4 & 0.2 & 2.4 & 2.3 & 2.4 \\
\hline York & 95.5 & 21 & 2.4 & 0.1 & 2.5 & 2.3 & 2.5 \\
\hline
\end{tabular}


Table 8.15. Continued

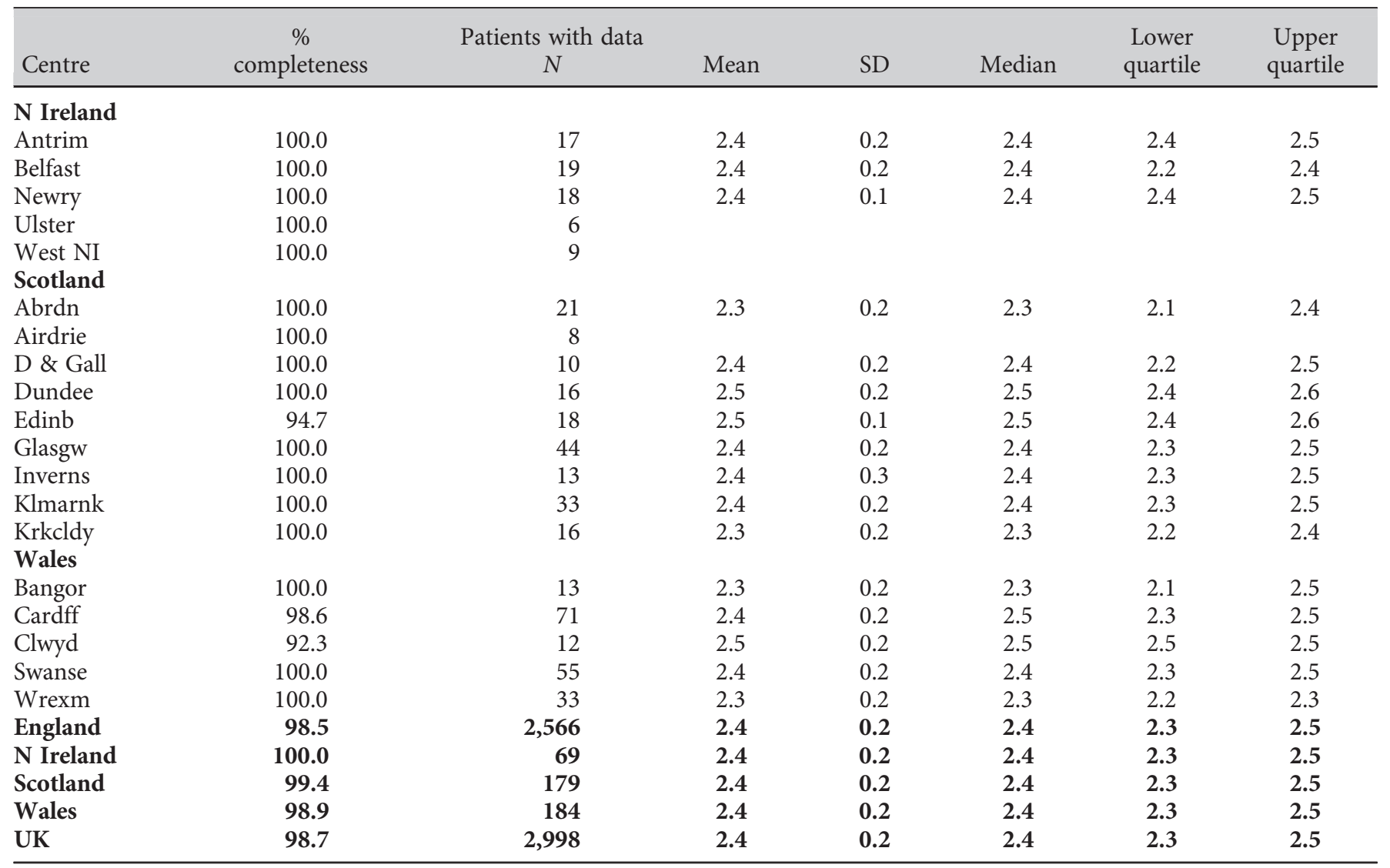

Blank cells: centres excluded from analysis due to low patient numbers or poor data completeness

${ }^{a}$ Cambridge renal centre was unable to submit adjusted calcium data for 2015

$\mathrm{b}$ n/a - no PD patients

Table 8.16. Percentage of peritoneal dialysis patients within, below and above the range for adjusted calcium (2.2-2.5 mmol/L) in 2015

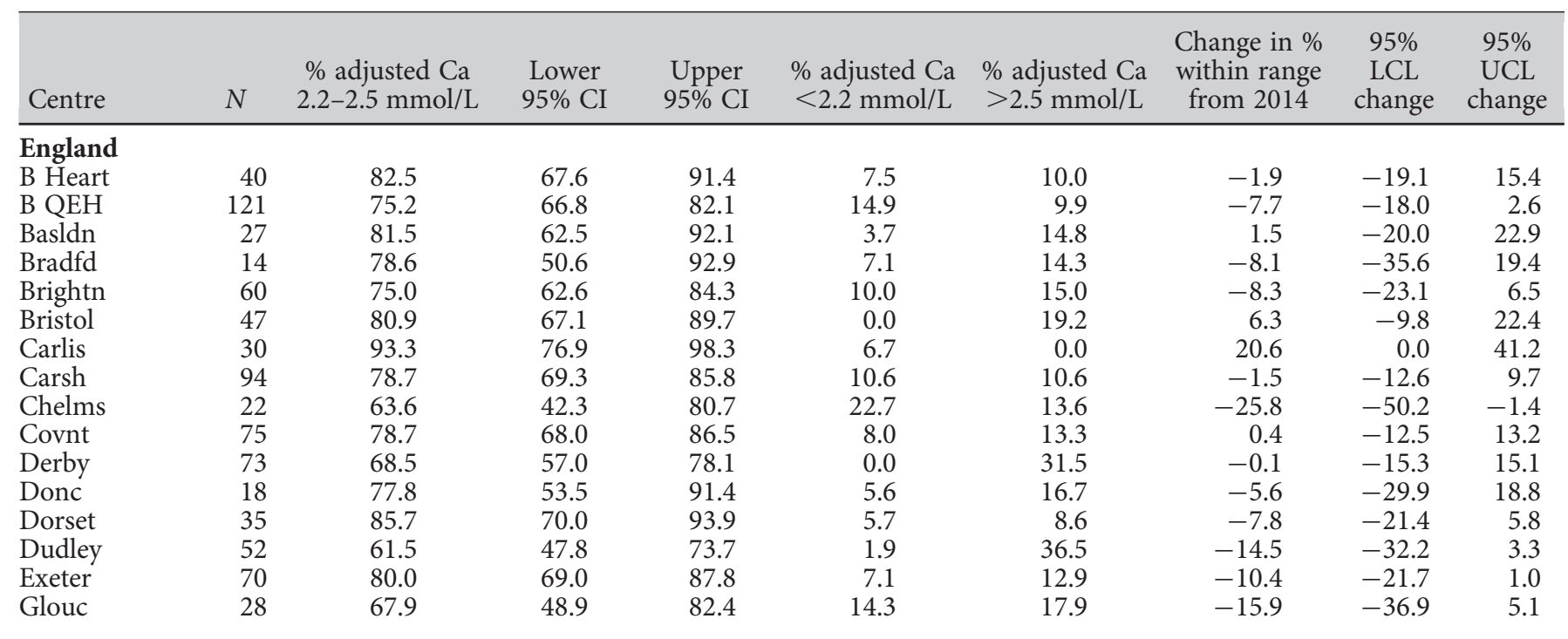


Table 8.16. Continued

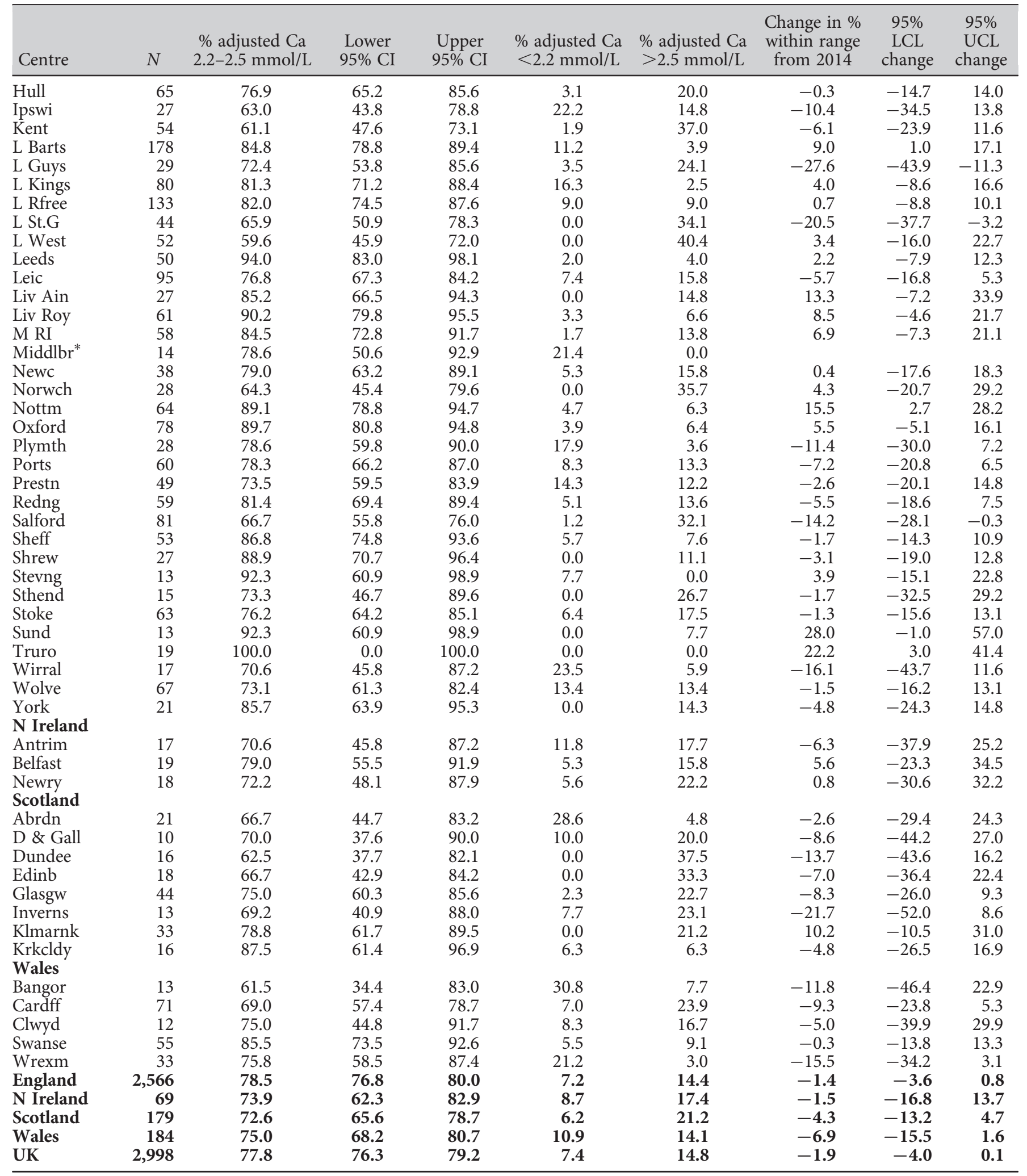

Centres missing from the table were excluded from analysis due to low patient numbers or poor data completeness

*Bank cells indicate no data for 2014 


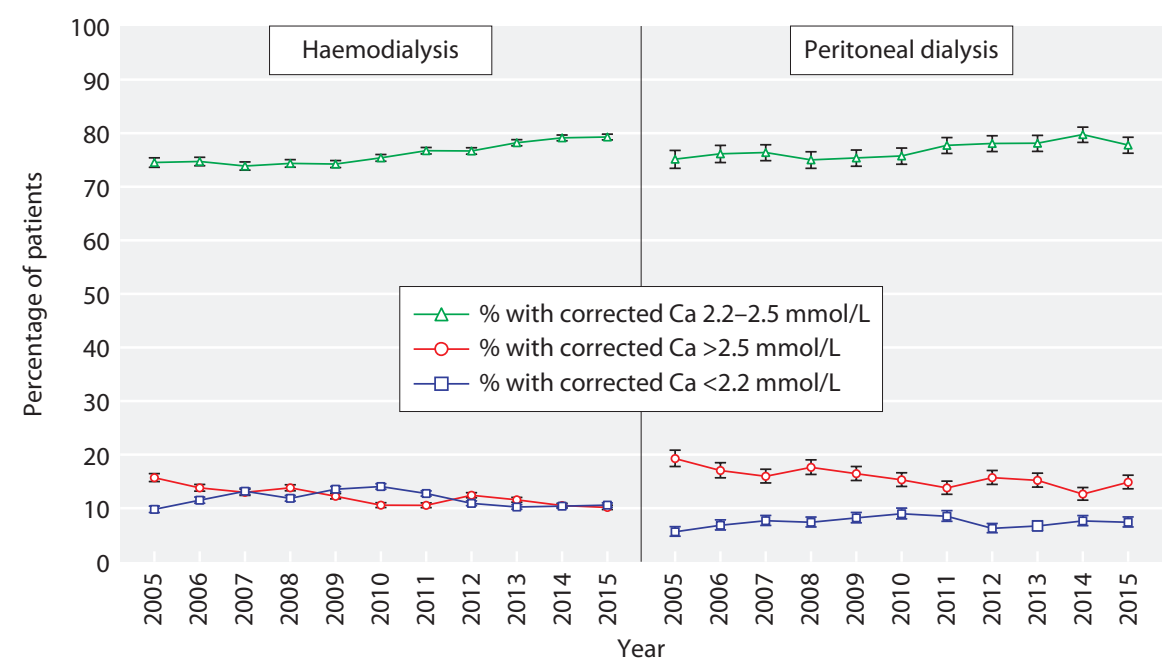

Fig. 8.19. Longitudinal change in percentage of patients with adjusted calcium $<2.2 \mathrm{mmol} / \mathrm{L}, 2.2-2.5 \mathrm{mmol} / \mathrm{L}$ and $>2.5 \mathrm{mmol} / \mathrm{L}$ by dialysis modality 2005-2015

\section{Phosphate}

In 2015 the following Renal Association clinical practice guideline regarding phosphate management was applicable:

Guideline 3.2 CKD-MBD: Serum phosphate in dialysis patients
'We suggest that serum phosphate in dialysis patients, measured before a "short-gap" dialysis session in haemodialysis patients, should be maintained between 1.1 and $1.7 \mathrm{mmol} / \mathrm{L}(2 \mathrm{C})^{\prime}$ [3]

For those receiving HD, 57.1\% of patients achieved a phosphate level between 1.1-1.7 $\mathrm{mmol} / \mathrm{L}$, the guideline

Table 8.17. Percentage of haemodialysis patients with serum phosphate within, below or above the target range of $1.1-1.7 \mathrm{mmol} / \mathrm{L}$, as specified in the RA guidelines, by centre in 2015

\begin{tabular}{|c|c|c|c|c|c|c|c|c|c|}
\hline Centre & $N$ & $\begin{array}{c}\text { \% phos } \\
1.1-1.7 \mathrm{mmol} / \mathrm{L}\end{array}$ & $\begin{array}{l}\text { Lower } \\
95 \% \mathrm{CI}\end{array}$ & $\begin{array}{l}\text { Upper } \\
95 \% \text { CI }\end{array}$ & $\begin{array}{l}\% \text { phos } \\
<1.1 \mathrm{mmol} / \mathrm{L}\end{array}$ & $\begin{array}{c}\% \text { phos } \\
>1.7 \mathrm{mmol} / \mathrm{L}\end{array}$ & $\begin{array}{c}\text { Change in } \% \\
\text { within range } \\
\text { from } 2014\end{array}$ & $\begin{array}{c}\text { 95\% } \\
\text { LCL } \\
\text { change }\end{array}$ & $\begin{array}{c}95 \% \\
\text { UCL } \\
\text { change }\end{array}$ \\
\hline \multicolumn{10}{|l|}{ England } \\
\hline B Heart & 396 & 54.8 & 49.9 & 59.6 & 10.6 & 34.6 & -0.3 & -14.4 & 13.8 \\
\hline B QEH & 905 & 62.7 & 59.5 & 65.8 & 14.6 & 22.8 & -1.1 & -13.6 & 11.5 \\
\hline Basldn & 152 & 54.0 & 46.0 & 61.7 & 17.1 & 29.0 & -2.2 & -17.6 & 13.2 \\
\hline Bradfd & 217 & 57.6 & 50.9 & 64.0 & 17.5 & 24.9 & 2.5 & -12.2 & 17.2 \\
\hline Brightn & 401 & 56.4 & 51.5 & 61.1 & 10.2 & 33.4 & -2.1 & -16.0 & 11.8 \\
\hline Bristol & 489 & 60.5 & 56.1 & 64.8 & 10.8 & 28.6 & 4.3 & -9.0 & 17.5 \\
\hline Carlis & 74 & 52.7 & 41.4 & 63.8 & 16.2 & 31.1 & -3.0 & -21.3 & 15.2 \\
\hline Carsh & 759 & 60.0 & 56.4 & 63.4 & 14.5 & 25.6 & -2.4 & -15.5 & 10.7 \\
\hline Chelms & 138 & 52.2 & 43.9 & 60.4 & 12.3 & 35.5 & -11.9 & -27.7 & 3.9 \\
\hline Colchr & 105 & 67.6 & 58.1 & 75.9 & 9.5 & 22.9 & 9.5 & -5.6 & 24.6 \\
\hline Covnt & 332 & 57.5 & 52.2 & 62.7 & 9.0 & 33.4 & -2.4 & -16.3 & 11.6 \\
\hline Derby & 221 & 58.4 & 51.8 & 64.7 & 16.7 & 24.9 & 0.3 & -14.1 & 14.7 \\
\hline Donc & 163 & 63.8 & 56.2 & 70.8 & 8.0 & 28.2 & -1.3 & -15.4 & 12.9 \\
\hline Dorset & 270 & 65.9 & 60.1 & 71.3 & 13.7 & 20.4 & 1.3 & -11.9 & 14.4 \\
\hline Dudley & 155 & 62.6 & 54.7 & 69.8 & 11.0 & 26.5 & 0.1 & -14.4 & 14.5 \\
\hline Exeter & 403 & 60.6 & 55.7 & 65.2 & 14.4 & 25.1 & -0.2 & -13.6 & 13.3 \\
\hline Glouc & 216 & 59.7 & 53.1 & 66.1 & 10.2 & 30.1 & -5.3 & -19.6 & 8.9 \\
\hline Hull & 326 & 57.4 & 51.9 & 62.6 & 12.0 & 30.7 & -6.1 & -20.1 & 7.9 \\
\hline Ipswi & 129 & 58.1 & 49.5 & 66.3 & 22.5 & 19.4 & 3.4 & -12.4 & 19.1 \\
\hline Kent & 395 & 54.9 & 50.0 & 59.8 & 7.3 & 37.7 & -2.7 & -16.8 & 11.4 \\
\hline L Barts & 928 & 51.5 & 48.3 & 54.7 & 16.7 & 31.8 & 3.3 & -10.7 & 17.4 \\
\hline
\end{tabular}


Table 8.17. Continued

\begin{tabular}{|c|c|c|c|c|c|c|c|c|c|}
\hline Centre & $N$ & $\begin{array}{c}\% \text { phos } \\
1.1-1.7 \mathrm{mmol} / \mathrm{L}\end{array}$ & $\begin{array}{l}\text { Lower } \\
95 \% \text { CI }\end{array}$ & $\begin{array}{l}\text { Upper } \\
95 \% \text { CI }\end{array}$ & $\begin{array}{c}\% \text { phos } \\
<1.1 \mathrm{mmol} / \mathrm{L}\end{array}$ & $\begin{array}{c}\% \text { phos } \\
>1.7 \mathrm{mmol} / \mathrm{L}\end{array}$ & $\begin{array}{l}\text { Change in \% } \\
\text { within range } \\
\text { from } 2014\end{array}$ & $\begin{array}{c}95 \% \\
\text { LCL } \\
\text { change }\end{array}$ & $\begin{array}{l}95 \% \\
\text { UCL } \\
\text { change }\end{array}$ \\
\hline L Kings & 522 & 61.7 & 57.4 & 65.8 & 17.1 & 21.3 & -5.2 & -18.2 & 7.8 \\
\hline L Rfree & 665 & 58.7 & 54.9 & 62.3 & 15.0 & 26.3 & 2.1 & -11.2 & 15.4 \\
\hline L St.G & 303 & 54.5 & 48.8 & 60.0 & 23.4 & 22.1 & -5.4 & -19.8 & 9.0 \\
\hline Leic & 839 & 55.1 & 51.7 & 58.4 & 13.0 & 31.9 & -1.2 & -14.8 & 12.5 \\
\hline Liv Ain & 155 & 58.1 & 50.2 & 65.6 & 27.1 & 14.8 & 6.1 & -9.0 & 21.2 \\
\hline Liv Roy & 354 & 58.5 & 53.3 & 63.5 & 13.3 & 28.3 & 3.8 & -10.0 & 17.6 \\
\hline M RI* & 445 & 51.9 & 47.3 & 56.5 & 16.6 & 31.5 & -2.4 & -16.7 & 12.0 \\
\hline Middlbr & 323 & 57.9 & 52.4 & 63.2 & 8.4 & 33.8 & 1.0 & -13.0 & 15.0 \\
\hline Newc & 285 & 57.9 & 52.1 & 63.5 & 11.2 & 30.9 & -1.1 & -15.3 & 13.0 \\
\hline Norwch & 311 & 65.0 & 59.5 & 70.1 & 12.5 & 22.5 & 2.3 & -10.8 & 15.4 \\
\hline Prestn & 531 & 57.1 & 52.8 & 61.2 & 8.9 & 34.1 & 3.7 & -10.0 & 17.3 \\
\hline Redng & 283 & 59.4 & 53.5 & 64.9 & 12.0 & 28.6 & -7.8 & -21.7 & 6.1 \\
\hline Salford* & 366 & 52.5 & 47.3 & 57.5 & 17.8 & 29.8 & 2.2 & -12.2 & 16.6 \\
\hline Sheff & 515 & 60.6 & 56.3 & 64.7 & 11.8 & 27.6 & 0.4 & -12.7 & 13.5 \\
\hline Shrew & 193 & 58.6 & 51.5 & 65.3 & 9.3 & 32.1 & -1.8 & -16.5 & 12.9 \\
\hline Stevng & 468 & 56.0 & 51.5 & 60.4 & 9.8 & 34.2 & -4.8 & -18.6 & 9.1 \\
\hline Sthend & 108 & 52.8 & 43.4 & 62.0 & 12.0 & 35.2 & -5.4 & -21.6 & 10.8 \\
\hline Stoke & 300 & 55.0 & 49.3 & 60.5 & 16.0 & 29.0 & -6.8 & -21.1 & 7.5 \\
\hline Truro & 145 & 63.5 & 55.3 & 70.9 & 11.0 & 25.5 & -4.0 & -18.5 & 10.6 \\
\hline Wirral & 176 & 51.1 & 43.8 & 58.4 & 21.0 & 27.8 & -0.7 & -16.1 & 14.6 \\
\hline Wolve & 284 & 48.6 & 42.8 & 54.4 & 23.2 & 28.2 & -4.4 & -19.5 & 10.7 \\
\hline York & 145 & 60.0 & 51.8 & 67.7 & 25.5 & 14.5 & -2.9 & -18.1 & 12.3 \\
\hline \multicolumn{10}{|l|}{ N Ireland } \\
\hline Dundee & 171 & 50.3 & 42.9 & 57.7 & 7.6 & 42.1 & -2.5 & -18.1 & 13.2 \\
\hline Edinb & 247 & 53.9 & 47.6 & 60.0 & 7.3 & 38.9 & 0.8 & -13.9 & 15.4 \\
\hline Glasgw & 535 & 53.1 & 48.8 & 57.3 & 8.8 & 38.1 & -1.8 & -15.9 & 12.4 \\
\hline Inverns & 77 & 49.4 & 38.4 & 60.4 & 9.1 & 41.6 & -7.4 & -25.4 & 10.7 \\
\hline Klmarnk & 124 & 58.1 & 49.2 & 66.4 & 20.2 & 21.8 & 2.0 & -13.4 & 17.4 \\
\hline Krkcldy & 132 & 60.6 & 52.0 & 68.6 & 10.6 & 28.8 & -3.7 & -18.6 & 11.2 \\
\hline \multicolumn{10}{|l|}{ Wales } \\
\hline Bangor & 78 & 65.4 & 54.2 & 75.1 & 12.8 & 21.8 & -0.4 & -16.4 & 15.5 \\
\hline Cardff & 459 & 59.7 & 55.1 & 64.1 & 13.1 & 27.2 & 1.7 & -11.7 & 15.1 \\
\hline Clwyd & 76 & 52.6 & 41.5 & 63.5 & 9.2 & 38.2 & 0.8 & -16.3 & 17.9 \\
\hline Swanse & 342 & 62.3 & 57.0 & 67.3 & 14.3 & 23.4 & -3.3 & -16.6 & 10.1 \\
\hline Wrexm & 99 & 53.5 & 43.7 & 63.1 & 36.4 & 10.1 & -2.3 & -18.8 & 14.1 \\
\hline England & 18,736 & 57.2 & 56.5 & 57.9 & 14.3 & 28.6 & -0.4 & -13.2 & 12.5 \\
\hline N Ireland & 577 & 56.5 & 52.4 & 60.5 & 15.3 & 28.3 & 1.8 & -11.8 & 15.5 \\
\hline Scotland & 1,714 & 55.0 & 52.7 & 57.4 & 11.7 & 33.3 & -1.2 & -14.6 & 12.2 \\
\hline Wales & 1,054 & 59.9 & 56.9 & 62.8 & 15.4 & 24.8 & -0.3 & -13.2 & 12.6 \\
\hline UK & 22,081 & 57.1 & 56.5 & 57.8 & 14.1 & 28.7 & -0.4 & -13.2 & 12.5 \\
\hline
\end{tabular}

Centres missing from the table were excluded from analysis due to low patient numbers or poor data completeness

${ }^{*}$ Salford and Manchester RI have been involved in the SPIRiT study - an RCT comparing low phosphate control (0.8 to $\left.1.4 \mathrm{mmol} / \mathrm{L}\right)$ with high phosphate group control (1.8 to $2.4 \mathrm{mmol} / \mathrm{L})$; HD patients only were recruited 
Table 8.18. Percentage of peritoneal dialysis patients within, below and above the range specified in the RA guideline for phosphate $(1.1-1.7 \mathrm{mmol} / \mathrm{L})$ in 2015

\begin{tabular}{|c|c|c|c|c|c|c|c|c|c|}
\hline Centre & $N$ & $\begin{array}{c}\% \text { phos } \\
1.1-1.7 \mathrm{mmol} / \mathrm{L}\end{array}$ & $\begin{array}{l}\text { Lower } \\
95 \% \mathrm{CI}\end{array}$ & $\begin{array}{c}\text { Upper } \\
95 \% \text { CI }\end{array}$ & $\begin{array}{l}\text { \% phos } \\
<1.1 \mathrm{mmol} / \mathrm{L}\end{array}$ & $\begin{array}{c}\% \text { phos } \\
>1.7 \mathrm{mmol} / \mathrm{L}\end{array}$ & $\begin{array}{l}\text { Change in \% } \\
\text { within range } \\
\text { from } 2014\end{array}$ & $\begin{array}{c}95 \% \\
\text { LCL } \\
\text { change }\end{array}$ & $\begin{array}{l}95 \% \\
\text { UCL } \\
\text { change }\end{array}$ \\
\hline B Heart & 40 & 50.0 & 35.0 & 65.0 & 10.0 & 40.0 & -3.1 & -26.3 & 20.1 \\
\hline B QEH & 121 & 56.2 & 47.3 & 64.8 & 6.6 & 37.2 & -6.7 & -19.2 & 5.7 \\
\hline Basldn & 27 & 59.3 & 40.3 & 75.8 & 7.4 & 33.3 & 3.3 & -23.6 & 30.1 \\
\hline Bristol & 47 & 63.8 & 49.3 & 76.2 & 4.3 & 31.9 & 9.3 & -9.7 & 28.3 \\
\hline Carlis & 30 & 63.3 & 45.1 & 78.4 & 13.3 & 23.3 & -9.4 & -34.8 & 16.0 \\
\hline Carsh & 93 & 58.1 & 47.8 & 67.6 & 9.7 & 32.3 & -3.2 & -16.7 & 10.3 \\
\hline Chelms & 22 & 40.9 & 22.8 & 61.8 & 13.6 & 45.5 & -9.1 & -40.0 & 21.8 \\
\hline Covnt & 74 & 67.6 & 56.2 & 77.2 & 13.5 & 18.9 & -5.9 & -20.3 & 8.6 \\
\hline Exeter & 70 & 72.9 & 61.3 & 82.0 & 7.1 & 20.0 & 3.0 & -11.4 & 17.3 \\
\hline Glouc & 28 & 60.7 & 42.0 & 76.7 & 7.1 & 32.1 & -1.5 & -25.4 & 22.5 \\
\hline Hull & 65 & 58.5 & 46.2 & 69.7 & 6.2 & 35.4 & -8.2 & -24.7 & 8.3 \\
\hline Ipswi & 27 & 63.0 & 43.8 & 78.8 & 14.8 & 22.2 & -3.7 & -28.5 & 21.1 \\
\hline Kent & 54 & 66.7 & 53.2 & 77.9 & 7.4 & 25.9 & 9.8 & -8.1 & 27.7 \\
\hline L Barts & 179 & 60.3 & 53.0 & 67.2 & 10.1 & 29.6 & -1.8 & -11.7 & 8.2 \\
\hline L Guys & 29 & 65.5 & 46.9 & 80.3 & 3.5 & 31.0 & 0.5 & -26.6 & 27.7 \\
\hline L Kings & 80 & 58.8 & 47.7 & 69.0 & 8.8 & 32.5 & -12.1 & -26.9 & 2.6 \\
\hline L Rfree & 133 & 60.9 & 52.4 & 68.8 & 6.0 & 33.1 & 4.0 & -8.1 & 16.0 \\
\hline L St.G & 44 & 65.9 & 50.9 & 78.3 & 11.4 & 22.7 & 6.8 & -13.4 & 27.0 \\
\hline L West & 52 & 63.5 & 49.7 & 75.3 & 7.7 & 28.9 & 1.0 & -18.0 & 19.9 \\
\hline Nottm & 64 & 71.9 & 59.7 & 81.5 & 6.3 & 21.9 & 4.8 & -10.6 & 20.2 \\
\hline Oxford & 78 & 61.5 & 50.4 & 71.6 & 3.9 & 34.6 & -5.6 & -20.7 & 9.5 \\
\hline Plymth & 28 & 64.3 & 45.4 & 79.6 & 17.9 & 17.9 & -19.0 & -41.2 & 3.2 \\
\hline Ports & 59 & 54.2 & 41.5 & 66.4 & 3.4 & 42.4 & -0.6 & -18.3 & 17.1 \\
\hline Prestn & 49 & 65.3 & 51.1 & 77.2 & 12.2 & 22.5 & -8.6 & -27.0 & 9.8 \\
\hline Redng & 59 & 78.0 & 65.7 & 86.8 & 5.1 & 17.0 & 7.5 & -8.1 & 23.1 \\
\hline Salford & 81 & 56.8 & 45.9 & 67.1 & 3.7 & 39.5 & 2.4 & -13.6 & 18.4 \\
\hline Sheff & 53 & 66.0 & 52.4 & 77.4 & 5.7 & 28.3 & -14.7 & -31.4 & 1.9 \\
\hline Shrew & 27 & 66.7 & 47.3 & 81.7 & 3.7 & 29.6 & 10.7 & -15.7 & 37.0 \\
\hline Stevng & 13 & 46.2 & 22.4 & 71.8 & 0.0 & 53.9 & -38.5 & -68.9 & -8.0 \\
\hline Sthend & 15 & 66.7 & 40.6 & 85.4 & 13.3 & 20.0 & 16.7 & -17.5 & 50.9 \\
\hline Stoke & 69 & 66.7 & 54.8 & 76.7 & 2.9 & 30.4 & -0.9 & -16.5 & 14.6 \\
\hline Sund & 13 & 46.2 & 22.4 & 71.8 & 7.7 & 46.2 & -3.9 & -41.5 & 33.8 \\
\hline Truro & 19 & 63.2 & 40.3 & 81.3 & 15.8 & 21.1 & -14.6 & -43.6 & 14.4 \\
\hline Wirral & 17 & 47.1 & 25.5 & 69.7 & 0.0 & 52.9 & 20.4 & -12.2 & 53.0 \\
\hline Wolve & 67 & 67.2 & 55.1 & 77.3 & 11.9 & 20.9 & 9.4 & -6.7 & 25.5 \\
\hline York & 21 & 57.1 & 36.0 & 76.0 & 14.3 & 28.6 & 0.0 & -29.9 & 29.9 \\
\hline
\end{tabular}


Table 8.18. Continued

\begin{tabular}{|c|c|c|c|c|c|c|c|c|c|}
\hline Centre & $N$ & $\begin{array}{c}\text { \% phos } \\
1.1-1.7 \mathrm{mmol} / \mathrm{L}\end{array}$ & $\begin{array}{l}\text { Lower } \\
95 \% \text { CI }\end{array}$ & $\begin{array}{l}\text { Upper } \\
95 \% \text { CI }\end{array}$ & $\begin{array}{c}\text { \% phos } \\
<1.1 \mathrm{mmol} / \mathrm{L}\end{array}$ & $\begin{array}{c}\% \text { phos } \\
>1.7 \mathrm{mmol} / \mathrm{L}\end{array}$ & $\begin{array}{c}\text { Change in \% } \\
\text { within range } \\
\text { from } 2014\end{array}$ & $\begin{array}{c}95 \% \\
\text { LCL } \\
\text { change }\end{array}$ & $\begin{array}{c}95 \% \\
\text { UCL } \\
\text { change }\end{array}$ \\
\hline \multicolumn{10}{|l|}{ N Ireland } \\
\hline Antrim & 17 & 58.8 & 35.2 & 79.0 & 11.8 & 29.4 & -2.7 & -38.0 & 32.6 \\
\hline Belfast & 19 & 63.2 & 40.3 & 81.3 & 10.5 & 26.3 & 9.8 & -23.5 & 43.1 \\
\hline Newry & 18 & 83.3 & 59.1 & 94.5 & 11.1 & 5.6 & 4.8 & -22.8 & 32.3 \\
\hline \multicolumn{10}{|l|}{ Scotland } \\
\hline Abrdn & 21 & 42.9 & 24.0 & 64.0 & 4.8 & 52.4 & -14.8 & -43.3 & 13.6 \\
\hline D \& Gall & 10 & 40.0 & 15.8 & 70.3 & 20.0 & 40.0 & -10.0 & -51.5 & 31.5 \\
\hline Dundee & 16 & 56.3 & 32.4 & 77.5 & 12.5 & 31.3 & -19.9 & -50.3 & 10.4 \\
\hline Edinb & 18 & 61.1 & 37.9 & 80.2 & 11.1 & 27.8 & -15.4 & -45.6 & 14.9 \\
\hline Glasgw & 44 & 61.4 & 46.4 & 74.5 & 6.8 & 31.8 & -1.5 & -23.0 & 20.0 \\
\hline Inverns & 13 & 46.2 & 22.4 & 71.8 & 7.7 & 46.2 & -17.5 & -56.8 & 21.8 \\
\hline Klmarnk & 33 & 39.4 & 24.4 & 56.7 & 3.0 & 57.6 & -14.9 & -38.4 & 8.6 \\
\hline Krkcldy & 16 & 68.8 & 43.3 & 86.4 & 0.0 & 31.3 & 30.3 & -4.6 & 65.2 \\
\hline \multicolumn{10}{|l|}{ Wales } \\
\hline Bangor & 13 & 46.2 & 22.4 & 71.8 & 7.7 & 46.2 & -0.5 & -37.6 & 36.5 \\
\hline Cardff & 70 & 62.9 & 51.0 & 73.3 & 1.4 & 35.7 & -6.7 & -22.4 & 9.0 \\
\hline Clwyd & 13 & 53.9 & 28.2 & 77.6 & 15.4 & 30.8 & -6.2 & -46.8 & 34.5 \\
\hline Swanse & 55 & 58.2 & 44.9 & 70.4 & 10.9 & 30.9 & -1.0 & -20.0 & 18.0 \\
\hline Wrexm & 33 & 57.6 & 40.5 & 73.0 & 3.0 & 39.4 & 1.1 & -25.3 & 27.4 \\
\hline England & 2,570 & 61.9 & 60.0 & 63.7 & 7.6 & 30.6 & -0.7 & -3.3 & 2.0 \\
\hline N Ireland & 69 & 71.0 & 59.3 & 80.5 & 10.1 & 18.8 & 2.6 & -13.5 & 18.7 \\
\hline Scotland & 179 & 52.5 & 45.2 & 59.7 & 7.3 & 40.2 & -9.1 & -19.3 & 1.2 \\
\hline Wales & 184 & 58.7 & 51.5 & 65.6 & 6.0 & 35.3 & -3.3 & -13.6 & 6.9 \\
\hline UK & 3,002 & 61.3 & 59.6 & 63.1 & 7.5 & 31.2 & -1.2 & -3.7 & 1.2 \\
\hline
\end{tabular}

Centres missing from the table were excluded from analysis due to low patient numbers or poor data completeness

*Bank cells indicate no data for 2014

specified by the RA (as opposed to the audit measure), and for those on PD this was 61.3\% (tables 8.17, 8.18).

There was inter-centre and inter-modality variation in the proportion of patients within the phosphate target range specified by the clinical guideline (figures 8.20 8.23 , tables $8.17,8.18$ ).

Funnel plots for HD patients with phosphate within the target range $(1.1-1.7 \mathrm{mmol} / \mathrm{L})$, show one centre (Birmingham Queen Elizabeth) attaining this standard in a significantly high proportion of patients (being above the $99.9 \%$ upper confidence interval following correction for centre size). In addition, two centres had achieved the serum phosphate control standard in a lower than expected proportion of patients (being below the lower $99.9 \%$ confidence interval): Portsmouth and London St Bartholomew's (figure 8.21). Differences in outlier status can be seen when this guideline target measure is applied compared to the audit measure of phosphate $<1.7 \mathrm{mmol} / \mathrm{L}$, namely fewer centres are found to be outliers.

Management of biochemical variables
The funnel plot for PD patients indicated that the control of phosphate levels was similar in all centres. No significant outliers were identified (figure 8.23).

Longitudinal analysis demonstrated a stable performance against the clinical guideline recommendation for those receiving HD and PD (figure 8.24).

\section{Parathyroid hormone}

At the beginning of 2015 the following RA guideline for PTH applied:

Guideline 4.2.1 CKD-MBD: Target range of serum $P T H$ in patients on dialysis

'We suggest that the target range for parathyroid hormone measured using an intact PTH assay should be between 2 and 9 times the upper limit of normal for the assay used (2C)' [3].

PTH results from 18,880 HD patients and 2,412 PD patients from England, Northern Ireland and Wales

Nephron 2017;137(suppl1):189-234 


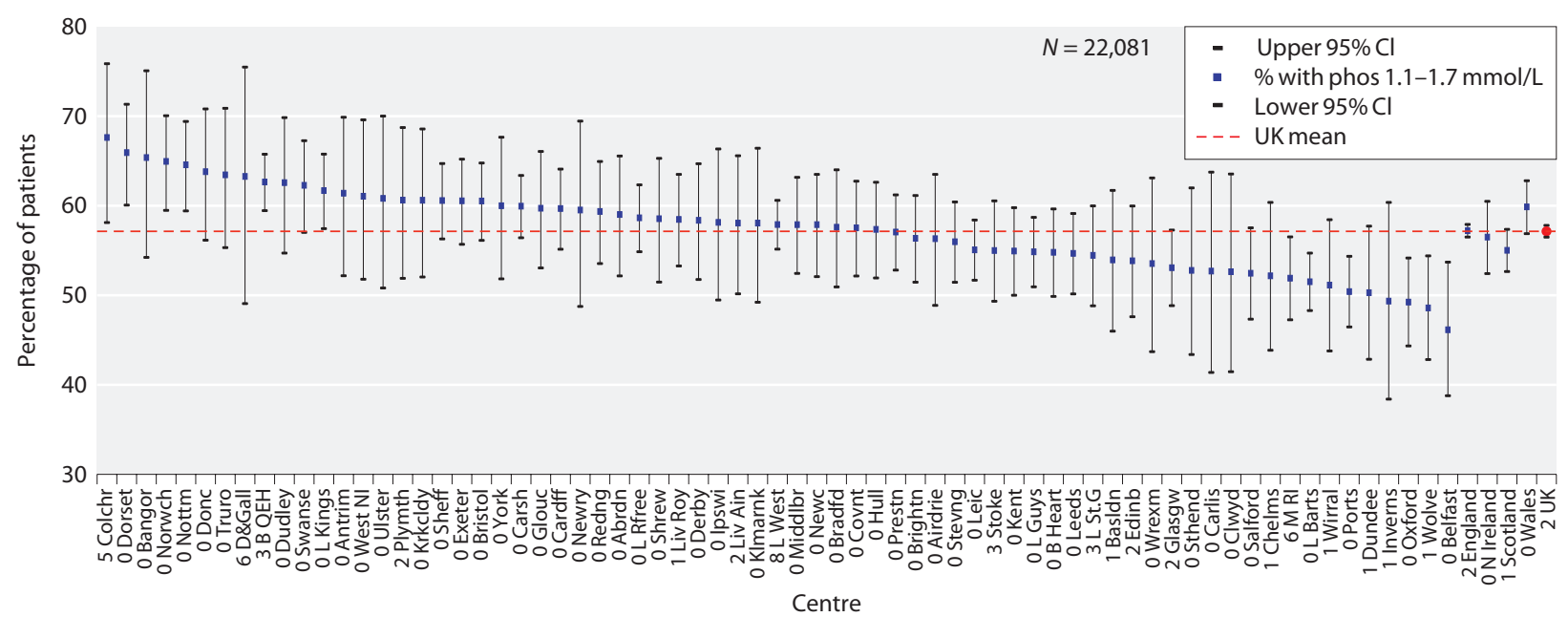

Fig. 8.20. Percentage of haemodialysis patients with phosphate within the range specified by the RA guideline (1.1-1.7 mmol/L) by centre in 2015

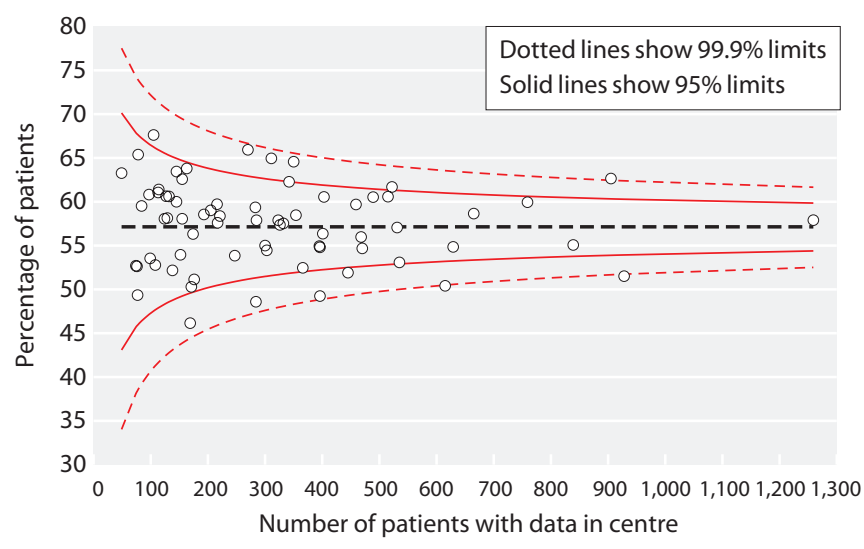

Fig. 8.21. Funnel plot of percentage of haemodialysis patients with phosphate within the range specified by the RA guideline $(1.1-1.7 \mathrm{mmol} / \mathrm{L})$ by centre in 2015

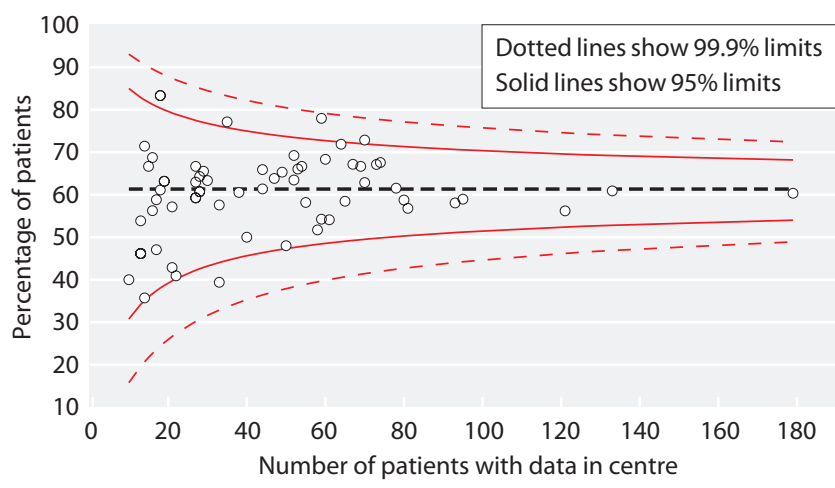

Fig. 8.23. Funnel plot of percentage of peritoneal dialysis patients with phosphate within the range specified by the RA guideline $(1.1-1.7 \mathrm{mmol} / \mathrm{L})$ by centre in 2015

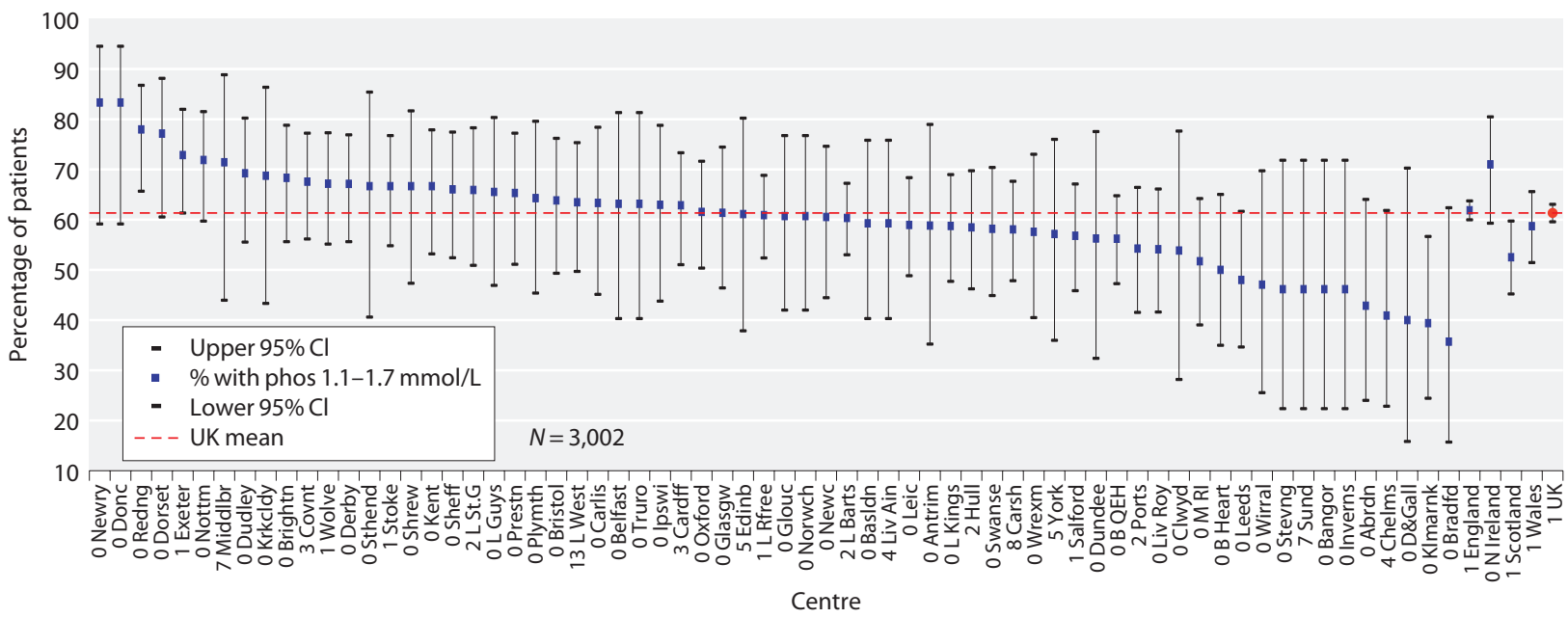

Fig. 8.22. Percentage of peritoneal dialysis patients with phosphate within the range specified by the RA guideline (1.1-1.7 mmol/L) by centre in 2015 


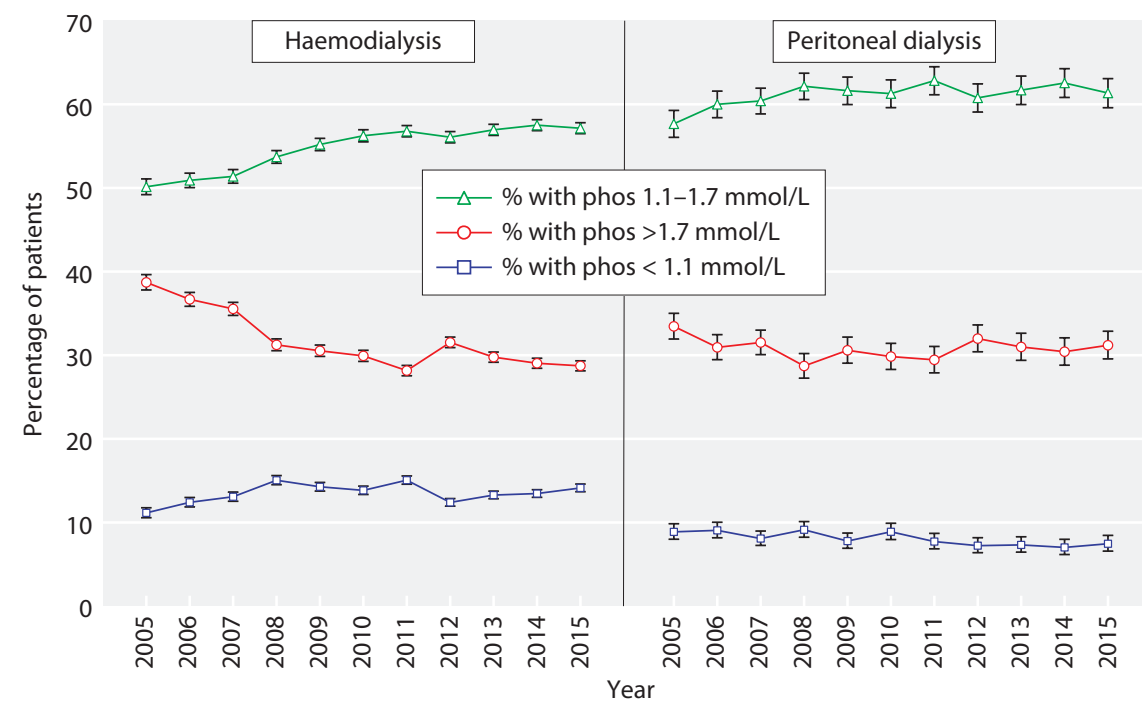

Fig. 8.24. Longitudinal change in percentage of patients with phosphate below, within and above the RA guideline by dialysis modality 2005-2015 were available for analysis from 2015. The data were $90.8 \%$ complete for $\mathrm{HD}$ patients and $84.4 \%$ for PD patients overall, although there was between centre variation (tables 8.19, 8.21). For the analyses, Birmingham Queen Elizabeth, Salford, Sheffield and Cambridge were excluded due to poor data completeness (including $0 \%$ returns from Cambridge for $\mathrm{HD}$ and $\mathrm{PD}$ patients and $0 \%$ returns from Salford for PD patients).

From 2004 to 2015 across the three countries, data completeness for PTH increased from $76.6 \%$ to $90.8 \%$ in HD patients, although this latest figure represents a
$3 \%$ fall compared to 2014 . For PD patients, the improvement in data completeness has been less marked: from $80.1 \%$ to $84.4 \%$ during $2004-2015$ and this latest figure represents a fall from $91.7 \%$ in 2014.

Median PTH amongst HD patients was $32 \mathrm{pmol} / \mathrm{L}$ (IQR 16-60 pmol/L) and amongst PD patients was $30 \mathrm{pmol} / \mathrm{L}$ (IQR $17-53 \mathrm{pmol} / \mathrm{L}$ ) for the three countries.

Of HD patients, 56.8\% (95\% CI 56.1-57.5\%) and of PD patients, 63.6\% (95\% CI 61.6-65.5\%) achieved a PTH between 16-72 pmol/L (tables 8.20, 8.22, figures $8.25,8.27)$.

Table 8.19. Summary statistics for PTH in haemodialysis patients in 2015

\begin{tabular}{|c|c|c|c|c|c|c|c|}
\hline Centre & $\begin{array}{c}\% \\
\text { completeness }\end{array}$ & $\begin{array}{c}\text { Patients with data } \\
\qquad N\end{array}$ & Mean & SD & Median & $\begin{array}{l}\text { Lower } \\
\text { quartile }\end{array}$ & $\begin{array}{l}\text { Upper } \\
\text { quartile }\end{array}$ \\
\hline \multicolumn{8}{|l|}{ England } \\
\hline B Heart & 99.0 & 393 & 51.8 & 47.5 & 40 & 21 & 68 \\
\hline $\mathrm{B} \mathrm{QEH}$ & 40.7 & 380 & & & & & \\
\hline Basldn & 98.0 & 150 & 43.7 & 35.9 & 33 & 18 & 59 \\
\hline Bradfd & 98.2 & 213 & 39.1 & 40.2 & 26 & 13 & 47 \\
\hline Brightn & 98.3 & 395 & 43.2 & 43.9 & 30 & 15 & 55 \\
\hline Bristol & 99.2 & 485 & 39.2 & 40.0 & 28 & 14 & 51 \\
\hline \multicolumn{8}{|l|}{ Camb* } \\
\hline Carlis & 97.3 & 72 & 28.5 & 26.3 & 24 & 10 & 37 \\
\hline Carsh & 96.2 & 732 & 66.8 & 63.0 & 47 & 25 & 89 \\
\hline Chelms & 99.3 & 138 & 46.9 & 41.4 & 33 & 19 & 62 \\
\hline Colchr & 94.6 & 105 & 31.0 & 33.0 & 21 & 12 & 37 \\
\hline Covnt & 99.4 & 330 & 34.6 & 38.8 & 23 & 12 & 43 \\
\hline Derby & 99.6 & 221 & 38.8 & 36.6 & 31 & 18 & 48 \\
\hline Donc & 99.4 & 162 & 59.6 & 48.1 & 46 & 27 & 74 \\
\hline Dorset & 99.6 & 269 & 30.0 & 33.5 & 20 & 11 & 37 \\
\hline Dudley & 97.4 & 151 & 37.2 & 35.6 & 27 & 11 & 54 \\
\hline Exeter & 98.8 & 398 & 20.4 & 20.3 & 15 & 7 & 26 \\
\hline Glouc & 95.4 & 206 & 35.9 & 38.9 & 25 & 13 & 49 \\
\hline Hull & 99.1 & 324 & 46.4 & 51.5 & 31 & 14 & 60 \\
\hline
\end{tabular}


Table 8.19. Continued

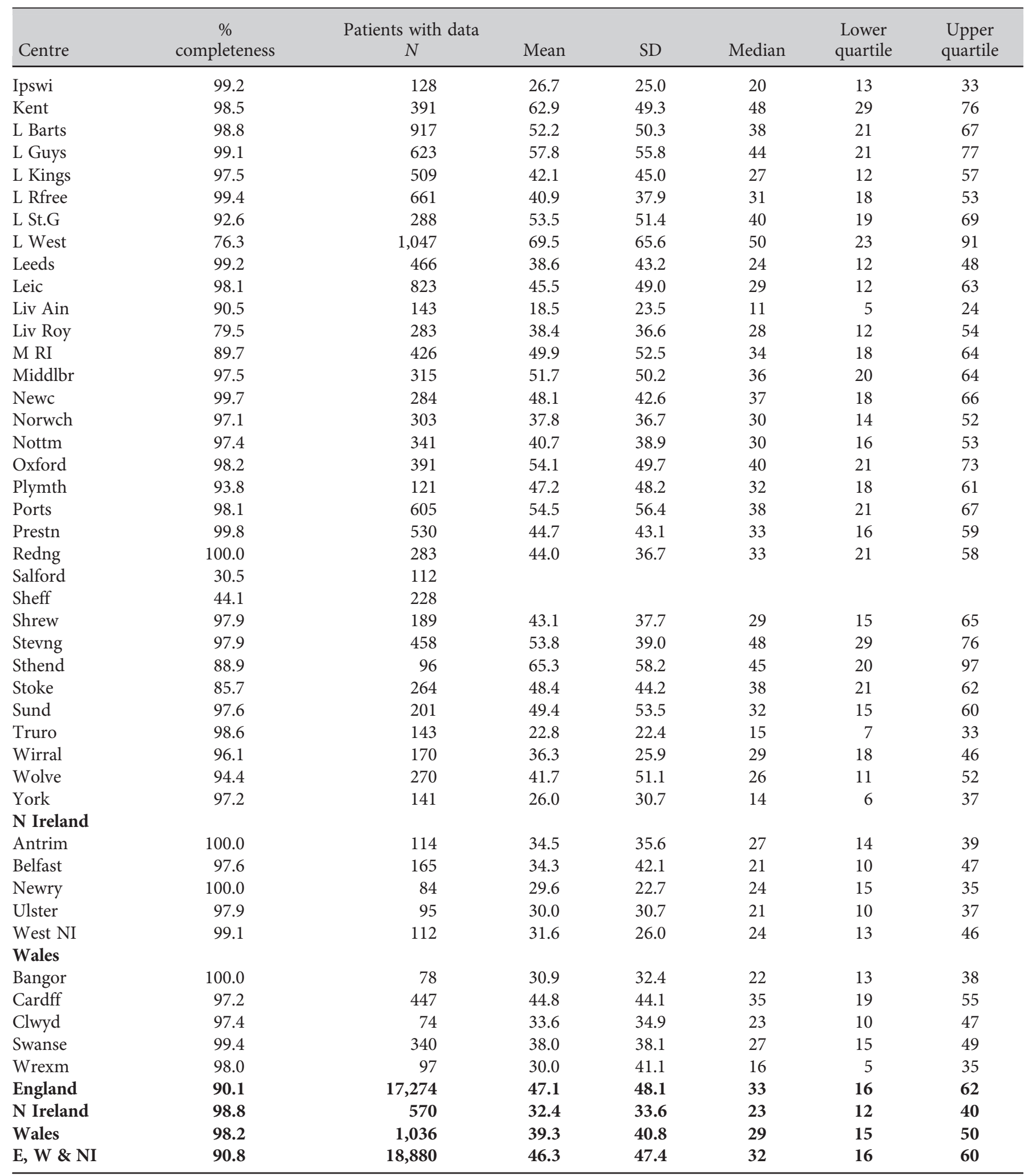

Blank cells: centres excluded from analysis due to low patient numbers or poor data completeness

${ }^{*}$ Cambridge renal centre was unable to submit PTH data for 2015 
Table 8.20. Percentage of haemodialysis patients within, below and above the range for PTH (16-72 pmol/L) in 2015

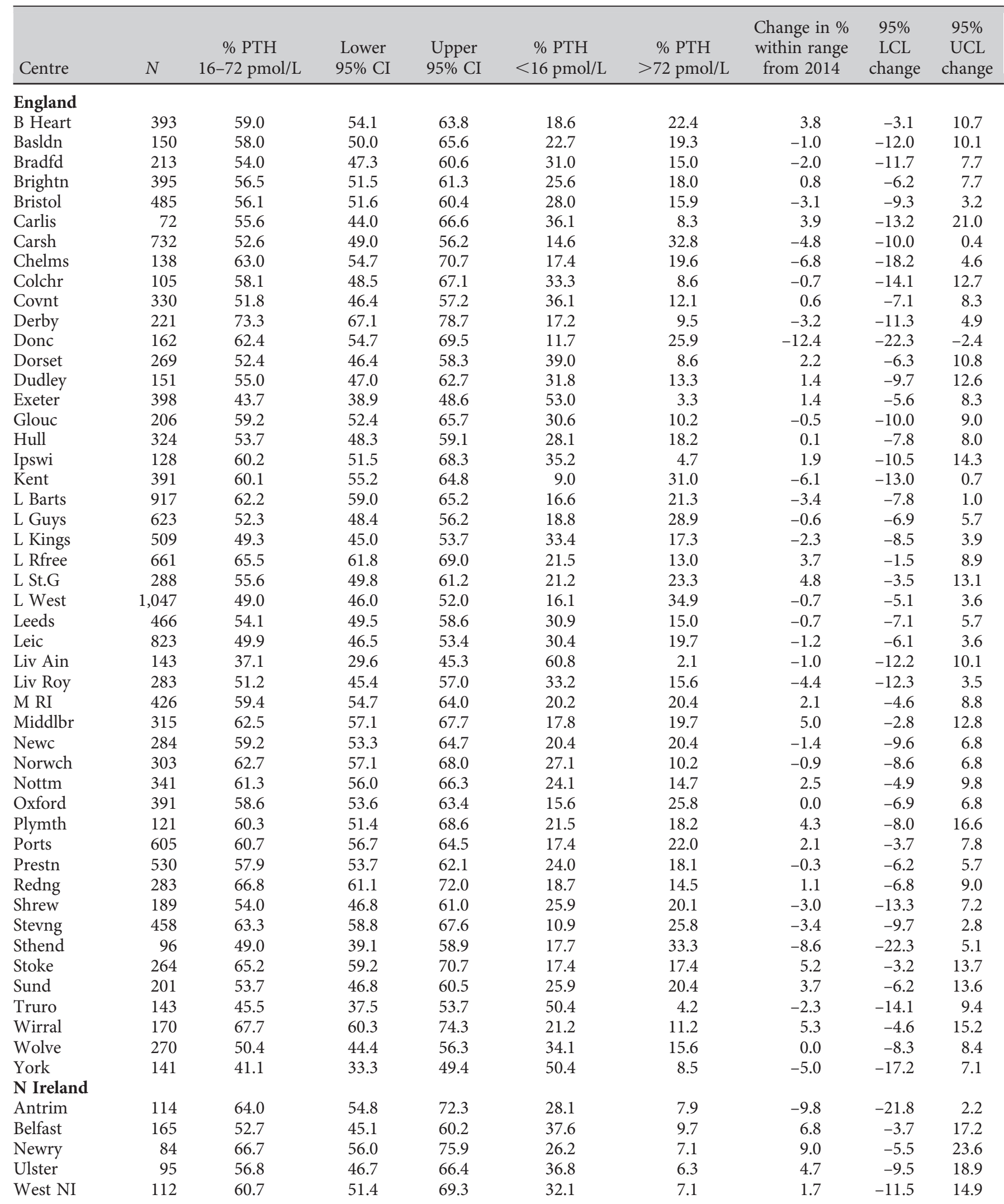


Table 8.20. Continued

\begin{tabular}{|c|c|c|c|c|c|c|c|c|c|}
\hline Centre & $N$ & $\begin{array}{c}\text { \% PTH } \\
16-72 \mathrm{pmol} / \mathrm{L}\end{array}$ & $\begin{array}{l}\text { Lower } \\
95 \% \text { CI }\end{array}$ & $\begin{array}{l}\text { Upper } \\
95 \% \text { CI }\end{array}$ & $\begin{array}{c}\% \mathrm{PTH} \\
<16 \mathrm{pmol} / \mathrm{L}\end{array}$ & $\begin{array}{c}\% \mathrm{PTH} \\
>72 \mathrm{pmol} / \mathrm{L}\end{array}$ & $\begin{array}{l}\text { Change in \% } \\
\text { within range } \\
\text { from } 2014\end{array}$ & $\begin{array}{c}95 \% \\
\text { LCL } \\
\text { change }\end{array}$ & $\begin{array}{c}95 \% \\
\text { UCL } \\
\text { change }\end{array}$ \\
\hline \multicolumn{10}{|l|}{ Wales } \\
\hline Bangor & 78 & 56.4 & 45.3 & 66.9 & 35.9 & 7.7 & -4.4 & -19.7 & 11.0 \\
\hline Cardff & 447 & 64.9 & 60.3 & 69.2 & 19.2 & 15.9 & 5.0 & -1.4 & 11.3 \\
\hline Clwyd & 74 & 54.1 & 42.7 & 65.0 & 35.1 & 10.8 & 1.6 & -14.2 & 17.3 \\
\hline Swanse & 340 & 62.7 & 57.4 & 67.6 & 25.6 & 11.8 & -3.6 & -11.6 & 4.4 \\
\hline Wrexm & 97 & 42.3 & 32.9 & 52.3 & 48.5 & 9.3 & -12.9 & -26.9 & 1.0 \\
\hline England & 17,274 & 56.5 & 55.7 & 57.2 & 24.0 & 19.5 & -0.9 & -1.9 & 0.2 \\
\hline N Ireland & 570 & 59.3 & 55.2 & 63.3 & 32.8 & 7.9 & 3.0 & -2.8 & 8.7 \\
\hline Wales & 1,036 & 60.6 & 57.6 & 63.6 & 26.5 & 12.9 & 0.2 & -4.1 & 4.5 \\
\hline E, W \& NI & 18,880 & 56.8 & 56.1 & 57.5 & 24.4 & 18.8 & -0.7 & -1.7 & 0.3 \\
\hline
\end{tabular}

Centres missing from the table were excluded from analysis due to low patient numbers or poor data completeness

Table 8.21. Summary statistics for PTH in peritoneal dialysis patients in 2015

\begin{tabular}{|c|c|c|c|c|c|c|c|}
\hline Centre & $\begin{array}{c}\% \\
\text { completeness }\end{array}$ & $\begin{array}{l}\text { Patients with data } \\
\qquad N\end{array}$ & Mean & SD & Median & $\begin{array}{l}\text { Lower } \\
\text { quartile }\end{array}$ & $\begin{array}{l}\text { Upper } \\
\text { quartile }\end{array}$ \\
\hline \multicolumn{8}{|l|}{ England } \\
\hline B Heart & 92.5 & 37 & 62.7 & 37.0 & 57.0 & 37.0 & 89.0 \\
\hline B QEH & 0.0 & 0 & & & & & \\
\hline Basldn & 100.0 & 27 & 34.7 & 24.6 & 27.0 & 19.0 & 48.0 \\
\hline Bradfd & 92.9 & 13 & 59.6 & 29.4 & 56.0 & 41.0 & 66.0 \\
\hline Brightn & 98.3 & 59 & 34.9 & 32.0 & 30.0 & 10.0 & 42.0 \\
\hline Bristol & 93.6 & 44 & 36.9 & 33.7 & 25.5 & 15.0 & 50.0 \\
\hline \multicolumn{8}{|l|}{ Camb* } \\
\hline Carlis & 90.0 & 27 & 28.7 & 21.6 & 22.0 & 12.0 & 43.0 \\
\hline Carsh & 85.2 & 86 & 72.6 & 54.1 & 60.0 & 35.0 & 108.0 \\
\hline Chelms & 91.3 & 21 & 69.2 & 62.7 & 53.0 & 23.0 & 79.0 \\
\hline Colchr & $\mathrm{n} / \mathrm{a}$ & & & & & & \\
\hline Covnt & 90.8 & 69 & 29.9 & 28.6 & 21.0 & 10.0 & 41.0 \\
\hline Derby & 93.2 & 68 & 29.3 & 16.2 & 26.5 & 18.0 & 37.0 \\
\hline Donc & 100.0 & 18 & 36.3 & 25.4 & 30.5 & 20.0 & 46.0 \\
\hline Dorset & 82.9 & 29 & 26.3 & 20.1 & 19.0 & 12.0 & 31.0 \\
\hline Dudley & 92.3 & 48 & 30.0 & 23.1 & 26.5 & 10.5 & 42.5 \\
\hline Exeter & 98.6 & 70 & 28.3 & 24.8 & 21.0 & 12.0 & 33.0 \\
\hline Glouc & 85.7 & 24 & 31.0 & 16.0 & 27.5 & 22.0 & 35.0 \\
\hline Hull & 81.8 & 54 & 27.2 & 27.0 & 21.0 & 12.0 & 32.0 \\
\hline Ipswi & 100.0 & 27 & 39.4 & 36.2 & 24.0 & 14.0 & 46.0 \\
\hline Kent & 100.0 & 54 & 53.2 & 42.2 & 38.0 & 19.0 & 67.0 \\
\hline L Barts & 96.2 & 175 & 41.6 & 27.8 & 35.0 & 21.0 & 56.0 \\
\hline L Guys & 82.8 & 24 & 34.3 & 23.0 & 26.5 & 18.0 & 52.0 \\
\hline L Kings & 90.0 & 72 & 65.8 & 54.8 & 45.5 & 23.0 & 108.5 \\
\hline L Rfree & 91.8 & 123 & 40.3 & 33.1 & 30.0 & 17.0 & 53.0 \\
\hline L St.G & 97.8 & 44 & 29.1 & 28.0 & 19.0 & 11.0 & 35.5 \\
\hline L West & 81.7 & 49 & 45.0 & 29.1 & 44.0 & 21.0 & 61.0 \\
\hline Leeds & 100.0 & 50 & 35.9 & 26.7 & 31.0 & 19.0 & 43.0 \\
\hline Leic & 94.7 & 90 & 41.2 & 44.8 & 26.5 & 12.0 & 47.0 \\
\hline Liv Ain & 71.4 & 20 & 19.9 & 19.7 & 18.5 & 8.5 & 24.0 \\
\hline Liv Roy & 91.8 & 56 & 24.9 & 15.0 & 22.0 & 14.5 & 29.5 \\
\hline M RI & 98.3 & 57 & 52.6 & 41.1 & 40.0 & 24.0 & 68.0 \\
\hline
\end{tabular}


Table 8.21. Continued

\begin{tabular}{|c|c|c|c|c|c|c|c|}
\hline Centre & $\begin{array}{c}\% \\
\text { completeness }\end{array}$ & $\begin{array}{c}\text { Patients with data } \\
\qquad N\end{array}$ & Mean & $\mathrm{SD}$ & Median & $\begin{array}{l}\text { Lower } \\
\text { quartile }\end{array}$ & $\begin{array}{l}\text { Upper } \\
\text { quartile }\end{array}$ \\
\hline Middlbr & 60.0 & 9 & & & & & \\
\hline Norwch & 64.3 & 18 & 34.7 & 24.2 & 30.5 & 22.0 & 43.0 \\
\hline Nottm & 98.4 & 63 & 45.6 & 43.7 & 36.0 & 20.0 & 55.0 \\
\hline Oxford & 98.7 & 77 & 40.5 & 26.4 & 35.0 & 20.0 & 59.0 \\
\hline Prestn & 100.0 & 49 & 30.9 & 20.9 & 27.0 & 16.0 & 41.0 \\
\hline Redng & 93.2 & 55 & 36.2 & 20.7 & 33.0 & 22.0 & 49.0 \\
\hline Salford & 0.0 & 0 & & & & & \\
\hline Sheff & 32.1 & 17 & & & & & \\
\hline Shrew & 96.3 & 26 & 40.4 & 30.2 & 31.0 & 16.0 & 62.0 \\
\hline Truro & 94.7 & 18 & 31.1 & 28.3 & 19.5 & 12.0 & 39.0 \\
\hline Wirral & 94.1 & 16 & 30.6 & 18.6 & 26.0 & 21.0 & 40.0 \\
\hline Wolve & 95.6 & 65 & 37.7 & 32.9 & 31.0 & 14.0 & 50.0 \\
\hline York & 100.0 & 22 & 37.8 & 36.9 & 18.0 & 10.0 & 72.0 \\
\hline \multicolumn{8}{|l|}{ N Ireland } \\
\hline Antrim & 100.0 & 17 & 33.8 & 34.4 & 20.0 & 17.0 & 48.0 \\
\hline Belfast & 100.0 & 19 & 32.3 & 27.3 & 28.0 & 16.0 & 38.0 \\
\hline Newry & 100.0 & 18 & 22.2 & 13.0 & 21.0 & 12.0 & 29.0 \\
\hline Ulster & 100.0 & 6 & & & & & \\
\hline West NI & 100.0 & 9 & & & & & \\
\hline \multicolumn{8}{|l|}{ Wales } \\
\hline Bangor & 100.0 & 13 & 39.1 & 25.5 & 35.0 & 22.0 & 58.0 \\
\hline
\end{tabular}

Blank cells: centres excluded from analysis due to small numbers or poor data completeness

* Cambridge renal centre was unable to submit PTH data for 2015

n/a - no PD patients

In 2015, the proportion of HD patients with a PTH above the upper limit of the range $(>72 \mathrm{pmol} / \mathrm{L})$ was $18.8 \%$ and the proportion below the lower limit of the range $(<16 \mathrm{pmol} / \mathrm{L})$ was $24.4 \%$.

The proportion of PD patients with PTH above the upper limit $(>72 \mathrm{pmol} / \mathrm{L})$ of the range was $13.9 \%$ and the proportion below the lower limit of the range $(<16 \mathrm{pmol} / \mathrm{L}$ ) was $22.6 \%$ (tables $8.20,8.22$ ).

There was significant variation by centre following unadjusted analyses for the proportion of patients below, within and above the range specified by the clinical performance measures. The funnel plot (figure 8.26) for HD patients showed above average achievement of the target range in Cardiff, Derby, Reading, London St Bartholomew's and London Royal Free and below average achievement for Liverpool Aintree, Exeter, Leicester, London Kings, London West and York. For PD patients (figure 8.28) Derby and Reading were above average achievement of the target range and there were no outliers below the $99.9 \%$ confidence interval for the target.

Longitudinal analysis of PTH control measures at the level of the three countries noted sustained reduction in the proportion of patients with low PTH levels 


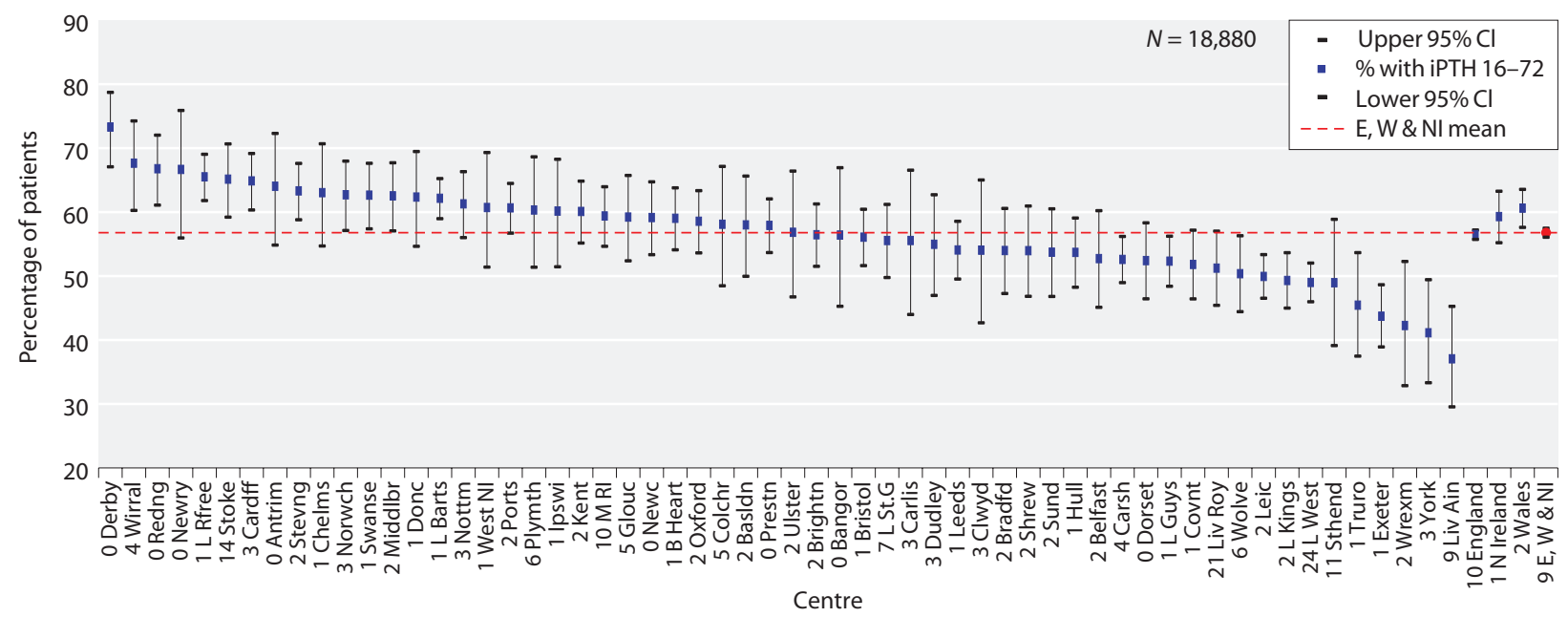

Fig. 8.25. Percentage of haemodialysis patients with PTH within range (16-72 pmol/L) by centre in 2015

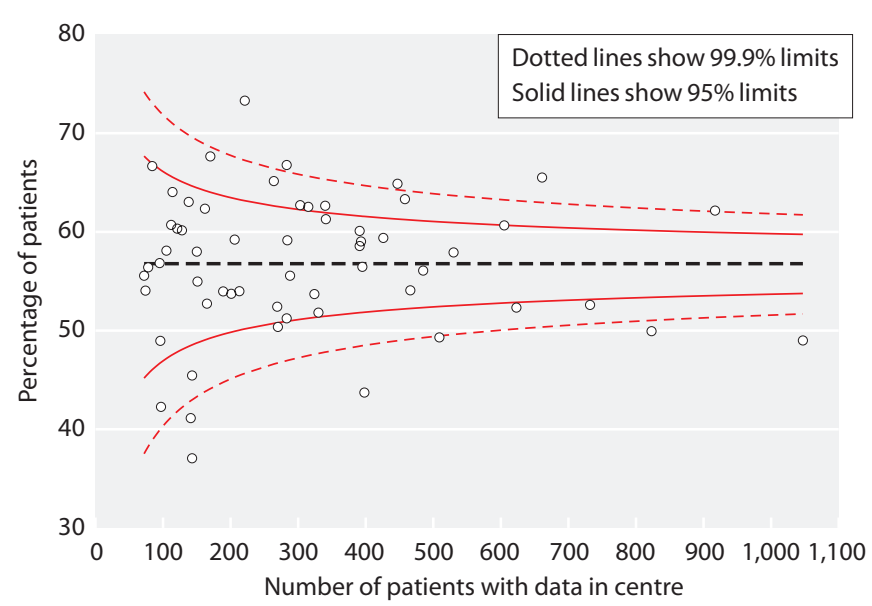

Fig. 8.26. Funnel plot of percentage of haemodialysis patients with PTH within range (16-72 $\mathrm{pmol} / \mathrm{L})$ by centre in 2015

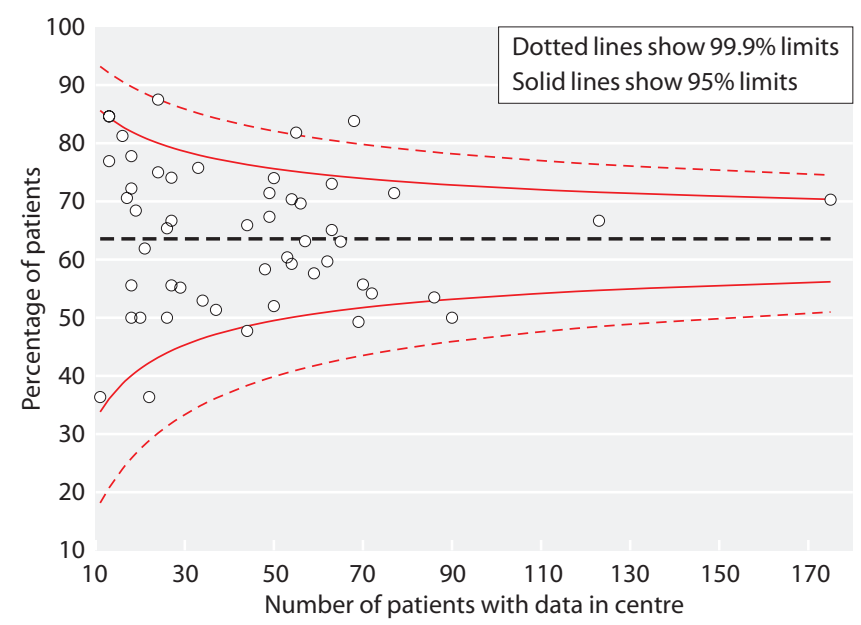

Fig. 8.28. Funnel plot of percentage of peritoneal dialysis patients with PTH within range (16-72 $\mathrm{pmol} / \mathrm{L})$ by centre in 2015

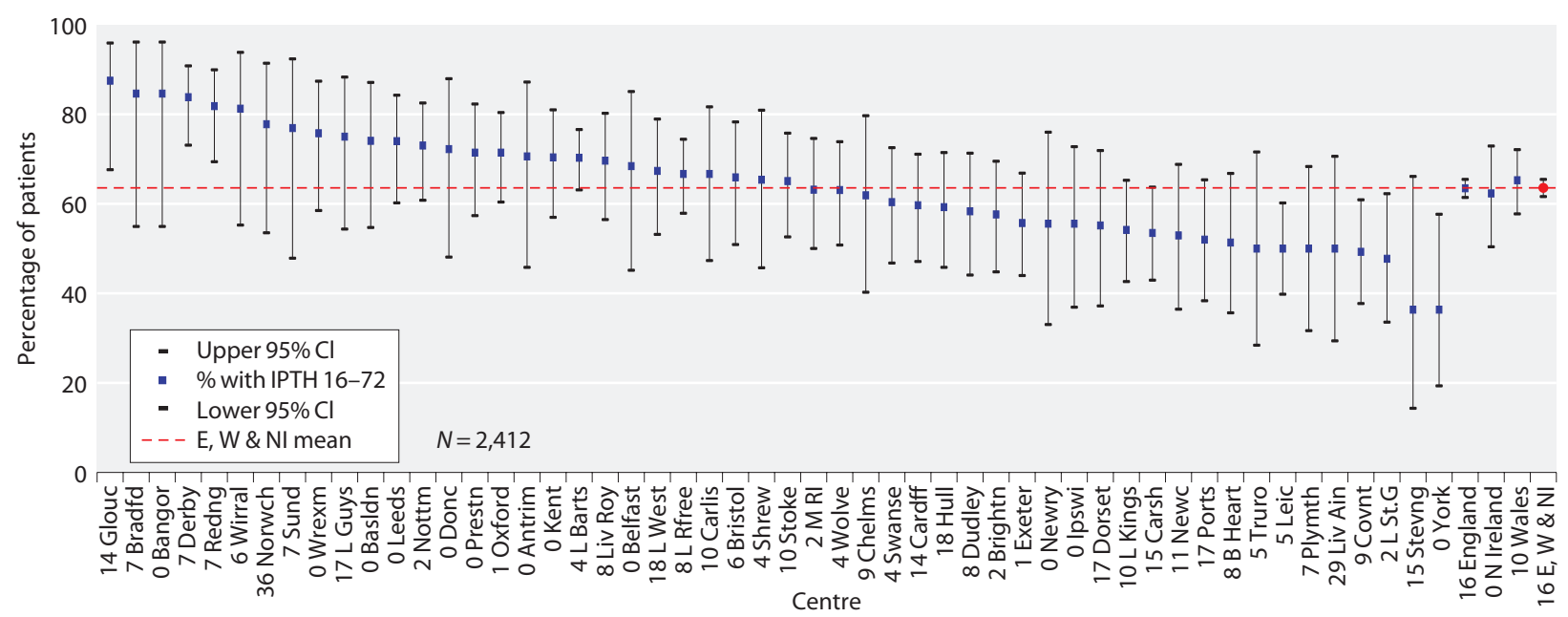

Fig. 8.27. Percentage of peritoneal dialysis patients with PTH within range (16-72 pmol/L) by centre in 2015 
Table 8.22. Percentage of peritoneal dialysis patients within, below and above the range for PTH (16-72 pmol/L) in 2015

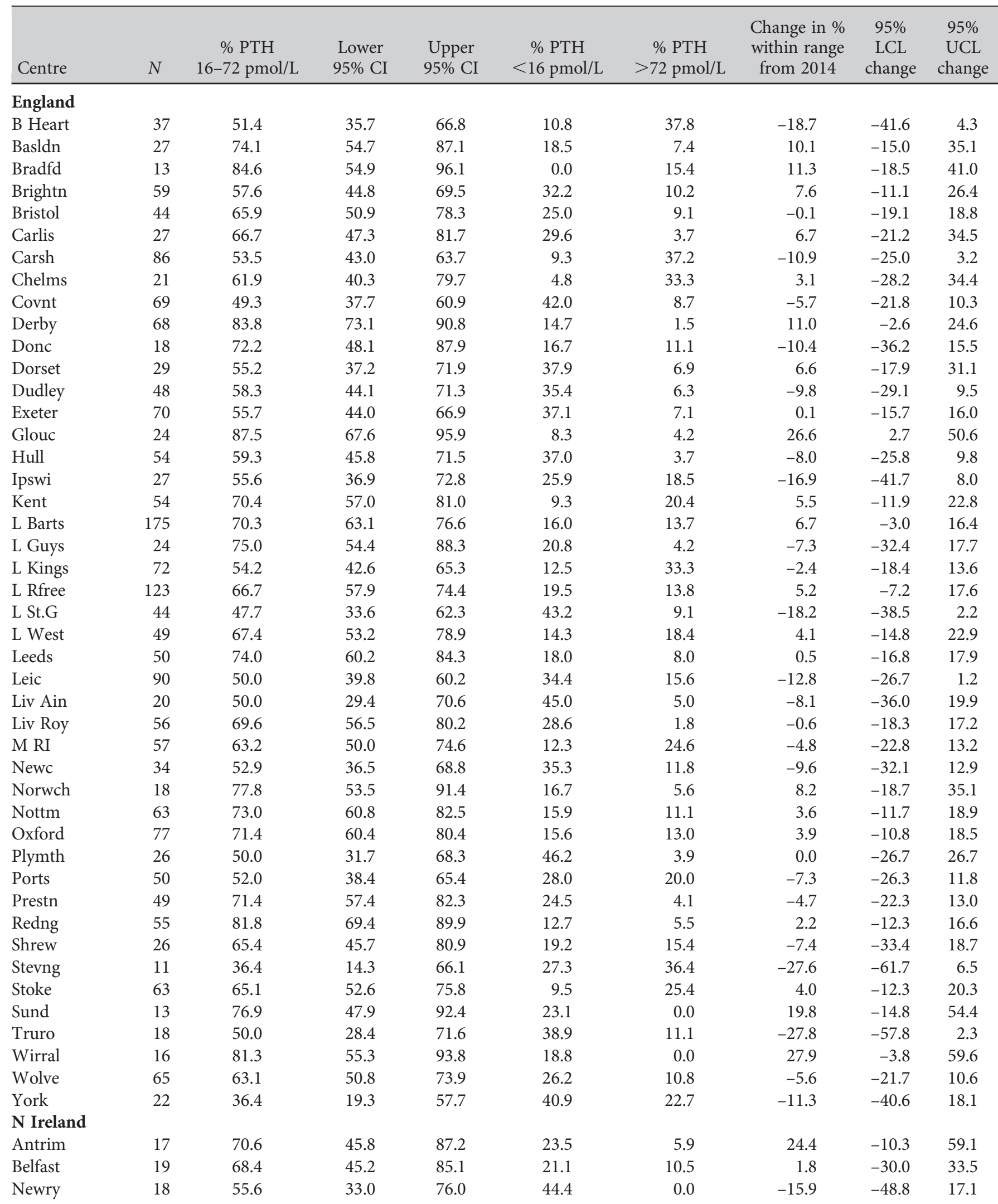


Table 8.22. Continued

\begin{tabular}{|c|c|c|c|c|c|c|c|c|c|}
\hline Centre & $N$ & $\begin{array}{c}\% \text { PTH } \\
16-72 \mathrm{pmol} / \mathrm{L}\end{array}$ & $\begin{array}{l}\text { Lower } \\
95 \% \text { CI }\end{array}$ & $\begin{array}{c}\text { Upper } \\
95 \% \text { CI }\end{array}$ & $\begin{array}{c}\text { \% PTH } \\
<16 \mathrm{pmol} / \mathrm{L}\end{array}$ & $\begin{array}{c}\% \mathrm{PTH} \\
>72 \mathrm{pmol} / \mathrm{L}\end{array}$ & $\begin{array}{c}\text { Change in } \% \\
\text { within range } \\
\text { from } 2014\end{array}$ & $\begin{array}{c}\text { 95\% } \\
\text { LCL } \\
\text { change }\end{array}$ & $\begin{array}{c}95 \% \\
\text { UCL } \\
\text { change }\end{array}$ \\
\hline \multicolumn{10}{|l|}{ Wales } \\
\hline Bangor & 13 & 84.6 & 54.9 & 96.1 & 7.7 & 7.7 & 13.2 & -17.5 & 43.9 \\
\hline Cardff & 62 & 59.7 & 47.1 & 71.1 & 11.3 & 29.0 & -14.4 & -31.3 & 2.5 \\
\hline Swanse & 53 & 60.4 & 46.8 & 72.5 & 32.1 & 7.6 & -11.1 & -29.3 & 7.2 \\
\hline Wrexm & 33 & 75.8 & 58.5 & 87.4 & 15.2 & 9.1 & -11.2 & -31.3 & 8.9 \\
\hline England & 2,176 & 63.5 & 61.4 & 65.5 & 22.7 & 13.9 & -1.2 & -4.0 & 1.5 \\
\hline N Ireland & 69 & 62.3 & 50.4 & 72.9 & 31.9 & 5.8 & 0.9 & -16.1 & 18.0 \\
\hline Wales & 167 & 65.3 & 57.8 & 72.1 & 18.0 & 16.8 & -9.1 & -19.1 & 1.0 \\
\hline E, W \& NI & 2,412 & 63.6 & 61.6 & 65.5 & 22.6 & 13.9 & -1.6 & -4.2 & 1.0 \\
\hline
\end{tabular}

Centres missing from the table were excluded from analysis due to low patient numbers or poor data completeness

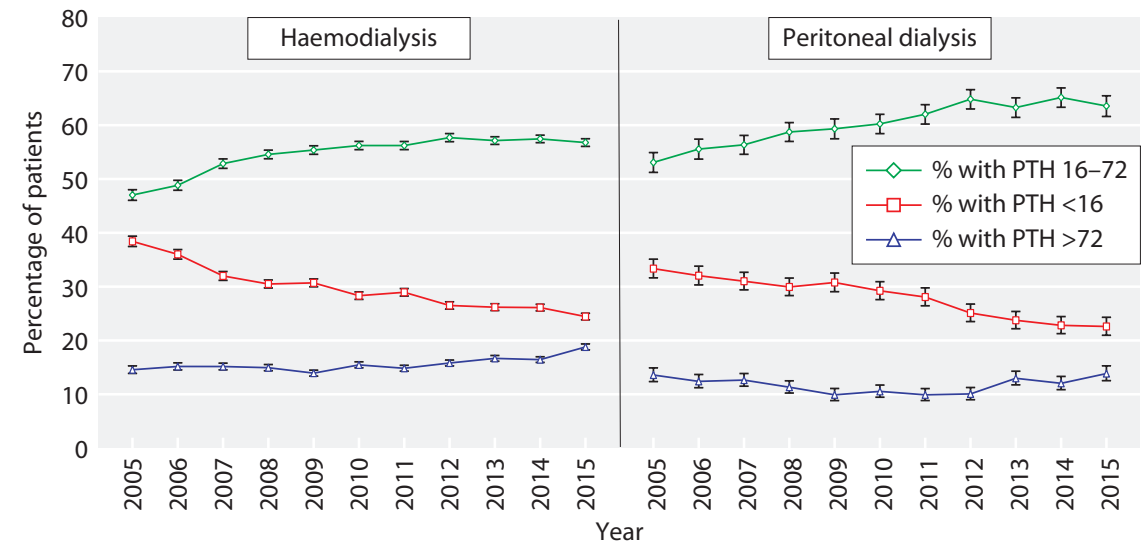

Fig. 8.29. Longitudinal change in percentage of patients with PTH within range (16-72 $\mathrm{pmol} / \mathrm{L})$ by dialysis modality 2005-2015
$(<16 \mathrm{pmol} / \mathrm{L})$ in HD and PD patients. Similarly, there has been a corresponding increase in the fraction of $\mathrm{HD}$ and PD patients with PTH levels being maintained within the 16-72 pmol/L range. The fraction of patients with PTH above range $(>72 \mathrm{pmol} / \mathrm{L})$ increased from $14.6 \%$ in 2005 to $18.8 \%$ in 2015 in those receiving HD but was unchanged in those receiving PD during the same period (figure 8.29). 